UNIVERSIDADE DE SÃO PAULO

FACULDADE DE FILOSOFIA, CIÊNCIAS E LETRAS DE RIBEIRÃO PRETO DEPARTAMENTO DE EDUCAÇÃO, INFORMAÇÃO E COMUNICAÇÃO PROGRAMA DE PÓS-GRADUAÇÃO EM EDUCAÇÃO

\title{
OS PARQUES INFANTIS DE RIBEIRÃO PRETO: UM ESTUDO SOBRE SUA IMPLANTAÇÃO
}

Débora Menengotti Ferreira 


\section{OS PARQUES INFANTIS DE RIBEIRÃO PRETO: UM ESTUDO SOBRE SUA IMPLANTAÇÃO}

Dissertação apresentada ao Programa de PósGraduação em Educação do Departamento de Educação, Informação e Comunicação da Faculdade de Filosofia, Ciências e Letras de Ribeirão Preto da Universidade de São Paulo, como parte das exigências para obtenção do título de Mestra em Ciências (versão corrigida).

Orientador: Prof. Dr. Sérgio César da Fonseca 
Autorizo a reprodução e divulgação total ou parcial deste trabalho, por qualquer meio convencional ou eletrônico, para fins de estudo e pesquisa, desde que citada a fonte.

Ferreira, Débora Menengotti

Os parques infantis de Ribeirão Preto: um estudo sobre a sua implantação. / Débora Menengotti Ferreira; Orientador: Sérgio César da Fonseca. - Ribeirão Preto, 2015.

121 p. : il.

Dissertação (Mestrado) - Universidade de São Paulo, 2015.

1.História da Educação. 2.Parques Infantis. 3. Ribeirão Preto. 
À minha família. 


\section{AGRADECIMENTOS}

Em primeiro lugar, gostaria de agradecer ao professor Sérgio César da Fonseca pelo incentivo na realização deste trabalho e pela confiança que depositou em mim desde os tempos da graduação. Todas as experiências que estes anos de estudo me proporcionaram, foram extremamente enriquecedoras não apenas do ponto de vista profissional mas, sobretudo, no âmbito pessoal, de maneira geral.

Agradeço também à minha companheira de pesquisa Bia Prandi. Entramos juntas na pós-graduação, compartilhamos o objeto de pesquisa e construímos uma relação muito pautada na colaboração e no respeito. Sua ajuda foi fundamental durante o desenvolvimento deste trabalho.

Em relação ao grupo de pesquisa, registro aqui a minha gratidão pelo esforço de vários graduandos que, de dentro do Arquivo Municipal e por meio das redes sociais, sempre se fizeram presentes, ora dividindo materiais de estudo, ora inventando formas hilárias de tornar o trabalho mais leve. Não cito o nome de todos para não correr o risco de deixar alguém de fora.

Não poderia deixar de citar os nomes dos professores que fizeram parte da minha banca de qualificação - Raquel Discini de Campos e Marco Antônio de Almeida. Vocês me inspiraram e fortaleceram muito com suas arguições.

Agradeço especialmente aos meus pais, não apenas pelo apoio que sempre representaram pra mim, mas também por sempre terem cuidado da minha formação com tanto zelo. Sem vocês, nada disso teria acontecido! Nada mesmo! O mérito deste título é de vocês!

Da família, não posso deixar de lamentar a ausência dos meus avós maternos Altina e Nenê Menengotti. Vocês foram os responsáveis pelas melhores memórias que tenho da minha infância e tenho certeza que, se estivessem por aqui, iam falar dessa minha conquista pros amigos e vizinhos com o maior orgulho do mundo. Que falta fazem! Agradeço por cada experiência de vida que me proporcionaram, por cada mimo, por cada passeio de bicicleta, por cada gesto de afeto.

Minhas irmãs Adriana e Beatriz, obrigada pela paciência. Sei que não foi fácil me aguentar estressada, precisando de silêncio e enchendo a casa de materiais de estudo. João Vitor, meu sobrinho e leão preferido: que alegria você trouxe pra minha vida! Foi durante a realização deste trabalho que você me fez compreender como é doce ser tia.

Ao Hugo, meu namorado, que esteve ao meu lado do início ao fim desta empreitada, deixo um agradecimento especial: talvez você tenha sido a pessoa (depois de mim) que mais leu este texto e que melhor compreendeu os questionamentos que busquei responder aqui. Obrigada por estar sempre disposto a me ouvir e me acompanhar e obrigada por compartilhar tantos sonhos comigo.

Aos meus colegas de trabalho que fizeram parte destes anos: o pessoal da ADEVIRP, as meninas da EMEI Neide Golfetto, da EMEI Teresa Hendrica Antonissen e da EMEI Wilson Roselino - obrigada pela torcida, pelo apoio, pelo carinho, pela cooperação, pelas risadas e por tudo que me ensinaram durante este período.

Por fim, agradeço à Faculdade de Filosofia, Ciências e Letras de Ribeirão Preto e seus professores pela formação que me proporcionaram, desde a graduação. Meu mundo ficou maior desde que entrei ali pela primeira vez. E vai crescer, cada vez mais! 
Com certeza, a liberdade e a poesia a gente aprende com as crianças.

(Manoel de Barros, 1999) 


\section{RESUMO}

O presente trabalho é o resultado de um estudo sobre a implantação de parques infantis na cidade de Ribeirão Preto a partir da década de 1950, tendo como fonte de pesquisa documentos de natureza oficial, além de jornais, legislação e fotografias encontrados no Arquivo Público e Histórico do município. Objetivando analisar a gênese da instituição na cidade e identificar as bases sobre as quais o atendimento à criança se deu no interior dos parques, foi necessário buscar as origens da proposta parqueana e cotejar os diferentes modelos que foram implantados. Para tal, contou-se com um levantamento bibliográfico de dissertações, teses e outros trabalhos de pesquisa acerca do conceito de Parques Infantis que colaborou no sentido de evidenciar que o modelo precursor, instalado na capital paulista na década de 1930 por orientação do então Chefe do Departamento de Cultura Mário de Andrade, apresentava pontos em comum com algumas iniciativas que vinham sendo articuladas em outros países desde o século XIX. Além disso, a bibliografia delineou aspectos acerca do Departamento de Educação Física do Estado de São Paulo (DEF-SP) que permitiram situar melhor este órgão no contexto da construção dos parques não apenas em Ribeirão Preto, mas em outras cidades do interior paulista, onde orientava a construção dos prédios e difundia um modelo mais voltado para a Educação Física. Para atingirmos os resultados obtidos na presente pesquisa foi realizado, ainda, um levantamento sistemático de cada instituição que funcionou na cidade a partir de 1951 - dados acerca do terreno e da localização dos parques, dos diferentes espaços e atividades desenvolvidas, dos funcionários e suas atribuições, entre outros. A leitura das fontes oficiais que consultamos, guardadas no Arquivo Municipal, sugere fortemente o protagonismo do Departamento de Educação Física do Estado na mobilização das autoridades políticas locais para a instalação dos parques e dizem respeito ao contexto político e social da cidade, que recebeu seu primeiro parque infantil em 1951. As fontes evidenciam que o modelo de instituição instalado em Ribeirão Preto se diferenciou do projeto criado por Mário de Andrade, em São Paulo, especialmente sob os aspectos culturais, que eram pouco ou quase nada considerados na rotina das crianças que frequentavam os parques da cidade em estudo.

Palavras-chave: História da Educação. Infância. Parques Infantis. Educação Física. Ribeirão Preto. 


\begin{abstract}
This work is the result of a study on the implementation of children's playgrounds in the city of Ribeirão Preto from the 1950s, and has as source official documents, and journals, legislation and photographs found in the Public Archives and History about the city. Aimed at analyzing the genesis of the institution in the city and identify the basis on which to attendance the child took place inside the playground, it was necessary to seek the origins of playground proposal and collate the different models that have been deployed. To this end, counted on a literature review of dissertations, thesis and other research papers about the concept of playgrounds that collaborated in order to show that the precursor model, installed in São Paulo in the 1930s under the guidance of then Chief Department of Culture Mário de Andrade, had points in common with some initiatives that were being articulated in other countries since the 19th century. In addition, the literature outlined aspects about the Department of Education of São Paulo State Physics (DEFSP) that allowed better situate this organ in connection with the construction of playground not only in Ribeirão Preto but in other cities of São Paulo, where directed the construction of buildings and diffused a friendlier model for Physical Education. To achieve the results obtained in this study, was conducted, a systematic survey of each institution that worked in the city since 1951 - data about the terrain and location of playgrounds, different spaces and developed activities, employees and their assignments, among others. Reading the official sources we consulted, stored in the Municipal Archive, strongly suggests the role of the state Department of Physical Education in the mobilization of local political authorities for the installation of playground and concern the political and social context of the city, which received its first playground in 1951. The sources show that the institution model installed in Ribeirao Preto differed design created by Mário de Andrade, in São Paulo, especially in the cultural aspects which were little or nothing considered in the routine of the children attending the city's playgrounds studied.
\end{abstract}

Keywords: History of Education. Childhood. Children's Playground. Physical Education. Ribeirão Preto. 


\section{LISTA DE ILUSTRAÇÕES}

Figura 1 - Meninas de um parque infantil paulistano em aula de costura e bordado 37

Figura 2 - Meninos de um parque infantil paulistano em aula de jogos

Figura 3 - Crianças em uma apresentação no Parque Infantil de Araraquara 53

Figura 4-Mapa dos Subsetores de Ribeirão Preto .... 76

Figura 5 - Fachada do Parque Infantil Peixe Abbade . 81

Figura 6-Aula de música no Parque Infantil Peixe Abbade 84

Figura 7 - Parque Infantil Amélia Junqueira 86

Figura 8 - Sala de espera da Clínica Odontológica noturna do Parque Infantil do Amélia Junqueira 89

Figura 9 - Educação física no Parque Infantil Amélia Junqueira .90

Figura 10 - Fachada do Parque Infantil da Vila Tibério 92

Figura 11 - Crianças esperando para o atendimento dentário no Parque Infantil da Vila Tibério

Figura 12 - Escovação dos dentes no Parque Infantil da Vila Tibério 97

Figura 13 - Dom Agnelo Rossi descerrando a fita de inauguração do Parque Infantil dos Bandeirantes ao lado do Cel. Alfredo Condeixa Filho e de um repórter, que acompanharam o evento. 102

\section{LISTA DE QUADROS}

Quadro 1 - Atribuições dos funcionários do DEF-SP 47

Quadro 2 - Prefeitos de Ribeirão Preto entre 1947 e 1981 56

Quadro 3 - Leis de criação dos parques que não têm implantação comprovada 106 


\section{SUMÁRIO}

1. INTRODUÇÃO ...........................................................................................................11

2. PARQUES INFANTIS: DIFERENTES EXPERIÊNCIAS............................................28

2.1 - O Modelo paulistano de Mário de Andrade ................................................................2 28

2.2 - A Educação Física e sua influência sobre os parques infantis ........................................ 40

2.3 - O Departamento de Educação Física do Estado de São Paulo......................................... 44

2.4 - Parques infantis disseminados pelo Departamento de Educação Física no interior

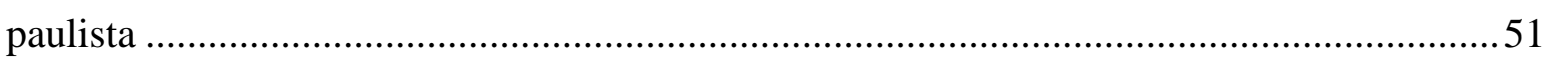

3. O TEMPO DOS PARQUES INFANTIS EM RIBEIRÃO PRETO: POLÍTICA E EDUCAÇÃ O ..........................................................................................................56

3.1 - Alguns apontamentos sobre a política municipal no período de surgimento dos

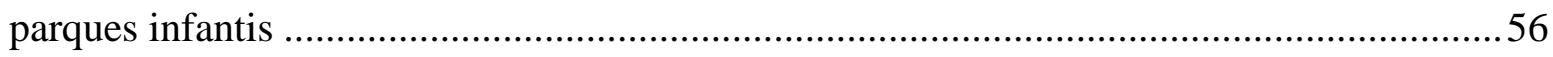

3.2 - Implantação dos parques infantis em Ribeirão Preto ……………………………….....68

3.3 - Os parques infantis se incorporam à paisagem ribeirão-pretana ................................... 75

3.3.1 - Parque Infantil Peixe Abbade ...........................................................................79

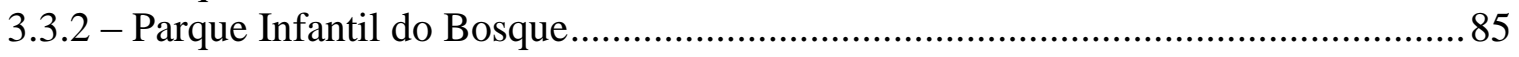

3.3.3 - Parque Infantil da Vila Tibério ..........................................................................91

3.3.4 - Parque Infantil de Guatapará ………………………….....................................97

3.3.5 - Parque Infantil da Vila Virgínia........................................................................98

3.3.6 - Parque Recanto Quarto Centenário......................................................................99

3.3.7 - Parque Infantil dos Bandeirantes ..................................................................... 100

3.3.8 - Parque Infantil de Santa Cruz do Jacques............................................................ 102

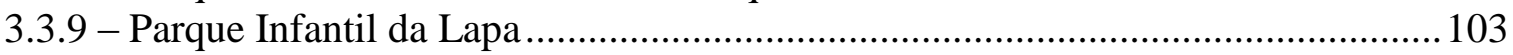

3.3.10 - Parque Infantil da Vila Lobato........................................................................ 104

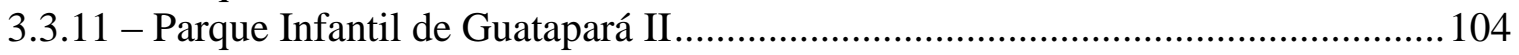

3.3.12 - Parque Infantil José Pedro Moreira ............................................................... 105

3.3.13 - Parque Infantil da Vila Albertina .................................................................. 105

3.3.14 - Parque Infantil dos Campos Elíseos ................................................................. 105

3.3.15 - Parques Infantis da Vila Paulista, da Vila Abranches e da Vila Seixas..............106

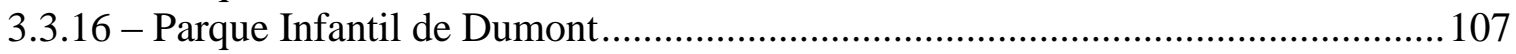

4. CONSIDERAÇÕES FINAIS ......................................................................................108

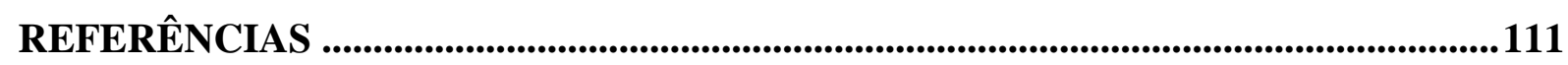




\section{INTRODUÇÃO}

Para a educação escolar na cidade de Ribeirão Preto, a segunda metade do século XX é o tempo de início de uma nova proposta de atendimento concretizada num modelo consideravelmente inédito: os parques infantis. Era uma espécie de instituição não exatamente escolar, cujo projeto fora criado na cidade de São Paulo ainda na década de 1930, e que objetivava promover a educação e a assistência por meio de rotinas de recreação.

O parque infantil é tomado como objeto de estudo motivador da presente pesquisa à medida que, enquanto pedagoga atuante na rede municipal de educação infantil, pretendo compreender os elementos que sustentavam o atendimento à criança em idade pré-escolar na cidade de Ribeirão Preto.

É importante considerar que o estudo em questão surgiu em parte de um trabalho anterior desenvolvido durante uma Iniciação Científica, em 2010, de título "Memórias do Magistério: idealização do passado e exercício da profissão no presente", coordenado pelo Professor Doutor Sérgio César da Fonseca, da Faculdade de Filosofia, Ciências e Letras de Ribeirão Preto, e apoiado pelo Programa Ensinar com Pesquisa, da Pró-Reitoria de Graduação da USP. A investigação realizada nesta ocasião objetivava resgatar a memória do atendimento à criança pequena pelo município de Ribeirão Preto nas décadas de 1960 e 1970, procurando desvendar questões relacionadas tanto às instituições existentes no período, quanto aos profissionais atuantes neste campo. Para tal, a metodologia utilizada contou com a pesquisa documental no Arquivo Público e Histórico de Ribeirão Preto - sobre as instituições que realizavam o atendimento da educação infantil na cidade - e com a coleta de depoimentos de professores que atuaram na educação escolar durante as décadas de 1960 a 1970. Nesse processo, observou-se que os materiais encontrados no Arquivo revelavam dados importantes acerca da formação da rede escolar municipal, mas, também, acerca dos parques infantis da cidade como parte integrante dela. Em complemento, as entrevistas com um grupo amostra de professoras que fizeram sua formação e ingressaram no magistério primário desde os anos 1950, em Ribeirão Preto, reforçou a necessidade de considerar os parques infantis como uma instituição importante na história da educação infantil na localidade.

Desse modo, o acesso aos documentos sobre parques infantis no Arquivo Municipal foi fundamental para ampliar o escopo dessa primeira pesquisa e levar a considerar a hipótese de que eles compuseram um tipo peculiar de equipamento público consagrado ao atendimento de criança sem, no entanto, ser a rigor equivalente à creche ou à pré-escola. A curiosidade em 
relação a este objeto motivou estudos mais aprofundados sobre sua origem (VIEIRA, 2004) que, consequentemente, permitiram o estabelecimento de questionamentos acerca de sua implantação em Ribeirão Preto e, por isso, motivaram o estudo do qual resulta o presente trabalho.

Nicanor Miranda ${ }^{1}$ (1941, p. 3), contemporaneamente à primeira geração de parques infantis paulistanos, explicava que "a história dos parques infantis, sua origem, evolução e propagação, não vem contada por inteiro em nenhum traçado geral ou especializado". Por este motivo, este estudo contou com uma busca de dissertações, teses e livros que tratavam das origens e do conceito da instituição parqueana e, no âmbito local, identificou documentos no Arquivo Público e Municipal de Ribeirão Preto $^{2}$, que foram fundamentais para a viabilização da pesquisa, tais como: textos jornalísticos, arquivos oficiais, almanaques, periódicos, arquivos institucionais e fotos. Trata-se, portanto, de um mergulho na história da educação infantil no Brasil e de uma investigação de suas ressonâncias no interior paulista.

A proposta de examinar a implantação dos parques infantis na cidade de Ribeirão Preto implicou em uma busca pela origem deste modelo de instituição. A pesquisa bibliográfica, nesse âmbito, foi fundamental para esclarecer o contexto histórico e as demandas sociais que deram origem a utilização dos espaços públicos para a organização de atividades educativas na Europa e em outros países da América no início do século XX. Posteriormente, buscou-se definir as características do modelo parqueano que foi instalado na capital paulista por Mário de Andrade, em 1934, durante o período em que esteve à frente do Departamento de Cultura de São Paulo e, investigando as razões para o declínio deste projeto, tratou-se do surgimento de um novo caráter de parques infantis (disseminados pelo interior paulista), baseado na educação física como atividade principal. A cidade de São Paulo, portanto, foi a primeira a instalar um parque infantil no Brasil e, ao que pudemos aferir, as outras cidades do Estado de São Paulo que instalaram seus parques infantis em seguida, já apresentavam um modelo bem distinto daquele desenvolvido por Mário de Andrade na capital paulista. Este novo modelo, que tinha suas bases definidas pelo Departamento de Educação Física do Estado (DEF-SP) chegou a Ribeirão Preto somente em 1951, quando a primeira instituição foi inaugurada na cidade.

\footnotetext{
${ }^{1}$ Nicanor Miranda foi um nome importante para o Departamento de Cultura da capital paulista, atuando como Chefe da Divisão de Educação e Recreio.

${ }^{2}$ Arquivo Público e Municipal de Ribeirão Preto: criado em 1992, faz parte da Secretaria Municipal da Cultura e tem como finalidades "localizar, recolher, recuperar, identificar, organizar e divulgar a documentação Pública e Particular sobre a história de Ribeirão Preto e Região, centrando-a a fim de que possa ser utilizada pela Administração Pública Municipal e pelo público em geral (estudantes, pesquisadores e interessados)". (ARQUIVO PÚBLICO E HISTÓRICO DE RIBEIRÃO PRETO, s/d.).
} 
Em vista desses precedentes, das mudanças identificáveis entre o parque infantil proposto por Mario de Andrade e o modelo elaborado pelo DEF-SP, a presente pesquisa colocou em primeiro plano Ribeirão Preto, uma vez que foram instalados na cidade mais de uma dezena de parques ao longo de duas décadas sob forte ingerência do citado Departamento de Educação Física. Ademais, procuramos colocar em primeiro plano os aspectos singulares do parque infantil quando tornado já uma instituição integrada ao meio escolar municipal público em Ribeirão Preto. Para tanto, as práticas cotidianas, os modos de organização, as escolhas pedagógicas foram características eleitas sob o fim de apontar a singularidade dos parques ante as escolas.

Para a consecução de propósitos semelhantes aos da presente pesquisa Eliane Lopes e Ana Maria Galvão (2001) indicam que os estudos voltados para a história da educação não se limitam às investigações sobre as instituições escolares ou sobre o pensamento pedagógico, mas abrangem questóes relacionadas ao cotidiano escolar, aos materiais e metodologias utilizados, as relaçóes professor-aluno/aluno-aluno e aos conteúdos trabalhados.

Segundo Marc Bloch (2001), a história consiste em um esforço voltado para o “conhecer melhor” e, portanto, depende de vestígios e se apresenta de maneira dinâmica - “o passado é, por definição, um dado que nada mais modificará. Mas o conhecimento do passado é uma coisa em progresso, que incessantemente se transforma e aperfeiçoa". (BLOCH, 2001, p. 75). Em consonância com esta ideia de que a história não é uma "ciência do passado" (BLOCH, 2001, p. 52), o francês Henri-Irénée Marrou (1978) classifica o trabalho do historiador como uma tarefa vinculada ao presente, já que busca revelar a realidade humana.

Transpondo esta noção para o âmbito da educação infantil no Brasil, infere-se que a ausência de estudos pode estar relacionada ao lugar que tal modalidade de ensino tem ocupado, ao longo da história, no interior das prioridades das políticas públicas para a educação e a infância no Brasil. A esse respeito, Sandra Vieira (1998) demonstra que a mobilização inicial em torno das ações para a infância no Brasil, na década de 1940, se relaciona muito mais aos aspectos de saúde e assistência com vistas à manutenção de um quadro político e econômico de fortalecimento da burguesia, já que a institucionalização de crianças era (des)organizada de modo a liberar a mulher para o trabalho e promover o desenvolvimento do país.

A observação do vínculo entre a educação e o desenvolvimento de uma nação constitui mais uma justificativa para a defesa do estudo histórico nessa área. Moysés 
Kuhlmann Jr. (2010) defende a educação como um fenômeno que influencia diretamente no processo de produção da história e que, portanto, não se limita ao âmbito educacional.

Nesta discussão acerca da história da educação, é essencial dar destaque para uma questão que, apesar de elementar, nem sempre é reconhecida pelas pesquisas na área: a escola não é o único lócus de educação. Sobre tal aspecto, Ana Lúcia Faria (1999b) faz menção ao significado do projeto de Mário de Andrade (não-escolar) para as crianças pequenas, ressaltando a originalidade da proposta elaborada pelo intelectual em relação às experiências que foram registradas em outras partes do mundo, que também relacionavam a educação ao jogo organizado. Além disso, coloca em destaque a vinculação propiciada pelos parques infantis no que diz respeito à saúde, à higiene, ao lúdico e à cultura. Com essas características, segundo Faria (1999b), a sociedade capitalista dos anos 1930 assistiu a um modelo de instituição que propunha a construção de uma identidade nacional, sem anular a infância e os operários que também a constituíam.

Com base na crença do valor dos parques e na tentativa de estimular um novo olhar acerca da educação pré-escolar (e escolar), do lúdico e da produção de cultura, este trabalho de pesquisa se propóe a fazer um estudo documental dos parques que foram instalados na cidade de Ribeirão Preto na década de 1950. Para tal empreendimento, foi necessária uma busca por fontes e uma análise rigorosa dos documentos obtidos.

Considerando que o objeto de estudo da presente pesquisa é, portanto, uma instituição não-escolar de educação infantil que foi extinta não apenas em Ribeirão Preto, mas em todas as cidades onde havia sido instalada, faz-se necessária a utilização de fontes registradas no período de sua instalação e funcionamento, tal como jornais, correspondências trocadas entre as autoridades políticas e publicações oficiais. Com estes materiais, localizados no Arquivo Público e Municipal de Ribeirão Preto, pretende-se compreender, mais especificamente, as ações que levaram à instalação dos parques e a forma que estas instituições assumiram na cidade.

O historiador francês Miguel de Certeau (2000) afirma que as fontes estão para a pesquisa histórica, assim como os tijolos estão para a construção de uma obra. Além disso, define que, por fonte, deve-se compreender qualquer material que testemunhe a vida humana do passado (documentos escritos, objetos, retratos, etc.). Cada tipo de fonte selecionada influencia o tipo de história que se vai produzir, ou, nas palavras do próprio historiador, "as fontes históricas determinam a paisagem que nós reconstituímos com a ajuda da documentação que elas nos forneceram”. (CERTEAU, 2000, p. 81). 
Sobre o processo de separação e reunião dos documentos, Certeau (2000, p. 81) observa que esta é uma "operação histórica" do pesquisador, pois transforma tais documentos e desenvolve "uma nova distribuição cultural" a partir deles - de modo a constituir os dados de maneira singular.

Para Certeau (2000), a primeira tarefa do estudo histórico consiste na separação, reunião e transformação de objetos em documentos. Em outras palavras, o pesquisador tem a missão de produzir os documentos, deslocando-os de seu tempo e de seu lugar de origem e fazendo com que eles se tornem peças de um novo conjunto.

Bloch (2001, p. 40) considera que "reunir os documentos que estima necessários é uma das tarefas mais difíceis do historiador. De fato ele não conseguiria realizá-la sem a ajuda de guias diversos: inventários de arquivos ou de bibliotecas, catálogos de museus, repertórios bibliográficos de toda sorte".

A existência das fontes históricas, entretanto, depende do elemento humano. Maria Eliza Borges (2003, p. 73) mostra, além de informar "sobre a cultura material de um determinado período histórico e de uma determinada cultura", as fontes atuam como "uma forma simbólica que atribui significados às representações e ao imaginário social. [...]. Todavia, sem compreender as vozes dos homens e mulheres de ontem, não podemos conhecer os sentidos que eles atribuíram às suas produções simbólicas".

Um alerta importante é feito por Marrou (1978): saber discernir sobre o que o documento tem a dizer é tarefa básica do historiador, já que ele nem sempre representa todas as informações acerca do momento histórico analisado. É importante, também, situar o leitor a respeito do lugar de onde fala o historiador, ou seja, reconhecer que as interpretações nunca são imparciais, mas, sim, leituras subjetivas. (CERTEAU, 2000).

Considerando que a presente pesquisa foi feita a partir de diferentes tipos de documentos (impressos jornalísticos, correspondências oficiais, fotografias e materiais institucionais), a investigação acerca da forma adquirida pelos parques municipais passou por um longo percurso de investigações e análises.

Thais Fonseca e Cynthia Veiga (2003) demonstram que, ao mesmo tempo em que a diversidade de fontes permite uma melhor apreensão do objeto de estudo, ela também dificulta a tarefa do pesquisador já que o coloca frente a um conjunto de informações nem sempre claras, imparciais e fidedignas. Por isso, objetivando esclarecer o lugar de onde se fala (como explicitado acima), é necessário fazer uma consideração importante: cada tipo de documento específico recebeu um tipo de tratamento específico. É o que veremos aqui. 
Inicialmente, trataremos do jornal como fonte de pesquisa, reconhecendo sua importância e chamando atenção para algumas características que influenciam no trabalho do pesquisador: em primeiro lugar, cumpre considerar que ele se constitui como um meio de comunicação de massa que trata de acontecimentos ligados ao cotidiano a partir de uma abordagem específica, já que é escrito por sujeitos determinados que expressam seus pontos de vista de forma explícita ou não, servindo a determinados grupos sociais - aspecto que faz do jornal um instrumento imparcial de manutenção de determinada ordem social. (CAMPOS, R., 2012).

Segundo Raquel Discini de Campos (2012), "March Bloch, Michel de Certeau, Jacques Le Goff e outros mestres da nossa oficina contemporânea demonstraram que é preciso estar atentos às intenções de quem produziu os jornais", tal como o papel que ele desempenha (ou almeja desempenhar) no interior das sociedades urbanas que têm acesso a ele.

Sobre este aspecto, é importante considerar que, no contexto da presente pesquisa, os jornais utilizados provavelmente chegavam a uma pequena parcela da população, já que a camada de trabalhadores operários da cidade de Ribeirão Preto, ao que se percebe, vivia de maneira extremamente marginalizada e não possuía meios de aproximar-se deste meio de comunicação, já que este acesso não prescinde da capacidade de leitura.

Por fim, Raquel Campos (2012) nos faz refletir sobre a sobrevivência deste material à ação do tempo. As razões pelas quais os jornais foram guardados e preservados (ainda que não adequadamente) nos dizem muito a respeito do seu valor social.

Os jornais utilizados no presente trabalho (“A Cidade”, "Diário de Notícias”, "Diário da Manhã" e "A Tarde") se caracterizam pela ampla circulação que tinham na cidade de Ribeirão Preto nos anos 1950, assim como pela periodicidade diária. Mario Manacorda (1989), ao tratar das pesquisas em História da Educação que usam esse tipo de fonte afirma que, assim, o conceito de educação fica mais abrangente, já que se articula à noção de cultura e de construção social. Segundo ele, o que se busca nas folhas impressas dos jornais é o sentido "que os homens do passado conferiram ao mundo por meio de imagens, palavras, notícias, entrevistas e propagandas estampadas em páginas hoje amareladas" (MANACORDA, 1989, p. 6). Além disso, procura-se "as formas como os homens do passado olharam o mundo, se deram a ver no mundo, buscaram ensinar o outro a olhar este mundo de uma determinada maneira". (CAMPOS, R., 2012, p. 62). 
É importante considerar, ainda, a questão da veracidade das fontes jornalísticas. Raquel Campos (2012) alerta que, apesar de não ser confiável sobre este aspecto, há de se reconhecer que, como qualquer outra fonte, o jornal apresenta uma visão "parcial e fragmentada por excelência, contendo mesmo uma boa dose de ficção”. A utilização deste material, portanto, carece de uma atividade essencial por parte do historiador: transformá-la em objeto de pesquisa. (CAMPOS, R., 2012, p. 66).

Em relação aos documentos oficiais, destaca-se na presente pesquisa a utilização de correspondências trocadas entre os prefeitos municipais do período estudado e o Departamento de Educação Física do Estado de São Paulo (ofícios, relatórios técnicos, plantas), as leis municipais que se referiam à implantação dos parques, almanaques comemorativos (1951, 1956 e 1962) e as fotografias tiradas nos parques durante o período de seu funcionamento.

As correspondências e as leis municipais serão tratadas aqui como produtores de fatos, enquanto os almanaques e as fotografias utilizadas na pesquisa servirão como produtores de dados - como já definiu Jacques Le Goff (1984) ao relativizar o conceito de documento.

Sobre as fotografias dos parques de Ribeirão Preto, temos o trabalho de Maria Beatriz R. Prandi (2015), que analisou a construção da imagem dos parques infantis a partir do estudo das fotografias. Ao adotar a observação deste material no presente estudo, pretendemos ilustrar determinadas situações e permitir com que o leitor compreenda determinados espaços e atividades parqueanas. Ao tratar da natureza da fotografia, Boris Kossoy (2007, p. 60) define que:

[...] ela nos mostra alguma coisa, porém seu significado a ultrapassa. Existe um conhecimento implícito nas fontes não-verbais como a fotografia; descobrir os enigmas que guardam em seu silêncio é desvendar fatos que the são inerentes e que não se mostram, fatos de um passado desaparecido, nebuloso que tentamos imaginar, re-criar, a partir de nossas imagens mentais, em eterna tensão com a imagem presente que concretamente vemos, limitada à superfície do documento: realidades superpostas.

Em relação aos documentos institucionais encontrados, vale considerar que, por meio deles, recolhemos informações acerca dos mais variados aspectos do funcionamento dos parques, tais como: livro-ponto dos professores, escala de férias dos professores, escala de substituição de professores, quadro de servidores, autorização para exames médicos, relatórios médicos, livros de chamadas, lista de material didático, notas de compras, registro de pessoas interessadas em trabalhar nos parques, orçamentos e balancete mensal beneficente do caixa parqueano. Esta coleta foi realizada no Arquivo Público e Municipal de Ribeirão Preto. 
Por fim, três trabalhos acadêmicos produzidos na cidade de Ribeirão Preto tiveram importância decisiva na elaboração do presente trabalho: o primeiro, intitulado "Memórias do magistério: idealização do passado e exercício da profissão no presente" consiste em um relatório de Iniciação Científica (citado anteriormente) que colheu depoimentos de professoras que atuaram nos parques da cidade (FERREIRA, 2010); o segundo, chamado “Contribuição para a história da educação infantil em Ribeirão Preto: experiências de funcionários e professoras das Escolas Municipais de Educação Infantil (EMEIs)”, também contribuiu através dos depoimentos de professoras e, além disso, colaborou com a construção de um ideário sobre os parques a partir da visão de funcionários (DARAHEM, 2011); e o terceiro, "A construção da imagem dos parques infantis de Ribeirão Preto das décadas de 1950 e 1960" fez não apenas o estudo das fotografias relacionadas à rotina parqueana, mas, também, ao significado social que a instituição teve na cidade nos anos de seu funcionamento. (PRANDI, 2015).

A partir desse conjunto de referências, pôde-se recuperar não somente os momentos exponenciais do processo de implantação dos parques, mas, também, investigar o seu cotidiano e sua influência na realidade dos sujeitos que dele se utilizaram.

Antes de adentrar na realidade ribeirão-pretana, é preciso explicitar que as raízes parqueanas tem uma genealogia longa, pois tem vínculos com o desenvolvimento de ideias, instituições e práticas puras de educação de crianças pequenas em espaços semi ou não escolares e que remontam até o século XIX. Os parques instalados em Ribeirão Preto talvez não apresentem uma conexão direta com as experiências mais antigas de educação infantil em espaços não escolares e recreativos, mas, por outro lado, eles podem ser reconhecidos como um modelo atualizado para a segunda metade do século XIX, onde a educação de crianças se desenvolveu em espaços paralelos à escola, tal como ocorreu em outros municípios do Estado de São Paulo no mesmo período.

Para nos aprofundarmos nestas raízes parqueanas, faz-se necessário rastrear a origem das concepções que estruturaram a instituição parqueana e desenvolver uma noção relativa às propostas que foram sendo construídas para este espaço de assistência-educação-recreação. Para este rastreamento, utilizamos como fonte principal os trabalhos de Nicanor Miranda (1941), Tizuko Kishimoto (1988), Carlos Niemeyer (2001) e Jussara Pimenta (2008).

Niemeyer (2001) trata do êxodo populacional que foi observado nas cidades industrializadas na segunda metade do século XIX, chamando atenção para a pobreza que foi estampada nas ruas europeias e norte-americanas. Além disso, identifica no discurso médico 
uma defesa do controle social dos espaços urbanos e da aplicação do conceito de higiene pública.

O público infantil, por ser considerado o mais prejudicado pelo movimento de urbanização, passou a receber atenção especial dos reformadores - o caráter nocivo das ruas deveria, então, ser combatido com políticas de assistência médico-pedagógica para este segmento social. A recreação serviria ao propósito de estimular a inteligência e a solidariedade social e, consequentemente, seria útil para a saúde das crianças. (Niemeyer, 2001).

Nicanor Miranda (1941) levanta duas hipóteses acerca do surgimento dos parques infantis: uma relacionada às concepções pedagógicas de Fröebel (debatidas desde o século XVIII) e outra relacionada ao contexto político e social da Alemanha nos fins do século XIX. Para compreender essas hipóteses, vamos considerar alguns pontos importantes sobre cada uma delas.

Em relação à primeira possibilidade, é necessário levar em conta as concepções pedagógicas de Fröebel. Sua defesa, neste cenário, era por uma educação que conciliasse a convivência da criança com a família à sua participação em atividades organizadas dentro de uma comunidade infantil; os objetivos destas experiências, para Fröebel, estavam relacionados à valorização das atividades espontâneas e dirigidas da criança. (MIRANDA, 1941).

A instituição idealizada por Fröebel era destinada a crianças entre 3 e 7 anos e possuía um currículo totalmente voltado para a percepção do corpo, a interação com a natureza, ao desenvolvimento dos trabalhos manuais e da capacidade de expressão das crianças.

Em relação à segunda hipótese defendida por Miranda (1941) sobre o surgimento dos parques, alguns dados apresentados por ele merecem ser apontados:

Konrad Kcoh e Hermann Corvinus, professores de um colégio de Brunschwick [Alemanha], [...] começaram a conduzir os seus alunos, duas vêzes por semana e nos feriados, a uma praça chamada St. Leonhardplatz, afastada da cidade onde moravam, afim de que aí pudessem dedicar-se à prática dos jogos motores. Três anos de experimentação e observação convenceram-nos da necessidade de realizar um trabalho de maior amplitude, mas, principalmente, organizado. [...] Tais circunstâncias fizeram com que o colégio em que Kcoh e Hermann lecionavam fôsse o primeiro em tôda a Alemanha, a incluir jogos motores em seu programa escolar. (MIRANDA, 1941, p. 4).

Difundida em toda a Alemanha, a campanha em prol dos jogos chegou à Dinamarca; em seguida, os Estados Unidos desenvolveram os playgrounds - tabuleiros de areia colocados 
em jardins públicos; a Holanda, Hungria, a Polônia e a França também inauguraram espaços públicos de lazer para as crianças.

Em Portugal, Pimenta (2008) demonstra que as instituições criadas a partir de 1933 destinavam-se não apenas à recreação, mas também contavam com “comida, roupas, sapatos, remédios, vacinas, radiografias, regras de higiene, de moral e de religião". (PIMENTA, 2008, p. 278).

Até 1941, diversos outros parques foram instalados no Canadá, México, Chile. Em cada país, os equipamentos de lazer se diferenciavam, mas a proposta de utilizar espaços abertos para a recreação das crianças mostrou ser uma característica frequente. (MIRANDA, 1941)

Analisando as duas hipóteses e a bibliografia acerca do tema, pode-se considerar que a influência de Fröebel no Brasil parece mais significativa do que as experiências de instalação de espaços públicos de lazer nos países da Europa e da América - até mesmo por uma questão de temporalidade. Kishimoto (1988) corrobora esta impressão ao identificar, nos documentos das unidades infantis instaladas em São Paulo, Rio de Janeiro e Bahia nos fins do século XIX, a presença da fundamentação teórica de Fröebel.

É importante considerar, ainda, que as instituições de atendimento à criança até o início dos anos de 1930 eram os asilos infantis (de caráter assistencial, para menores abandonados, órfãos ou delinquentes), as creches (de caráter assistencial, para órfãos ou filhos de operários com menos de 2 anos), as escolas maternais (de caráter educativo, para filhos de operários entre 2 e 4 anos) e os jardins de infância (de características distintas em cada localidade, mas, em geral, de caráter educativo para filhos de operários que têm entre 4 a 6 anos). (KISHIMOTO, 1988).

A partir desta contextualização, nota-se que a proposta assistencial, educativa e recreativa dos parques se constituía como algo totalmente inédito no país durante o início do século XX. Vale considerar, entretanto, que o movimento da Escola Nova também influenciou as bases deste projeto, servindo de "solo fértil para germinar" (NIEMEYER, 2001, p. 26). Para tratar deste aspecto, é necessário articular algumas questões relacionadas à contextualização do período histórico que vai de 1920 a 1930 no Brasil. Micael Herschmann (1994, p. 30) caracteriza este momento como a "descoberta do Brasil" por parte dos intelectuais da época "e de busca de um rompimento definitivo com o provincianismo, o formalismo e a repetição de velhas fórmulas que não davam mais conta de um cotidiano cada vez mais urbano e industrial". 
Sobre a transformação dos "artistas" em "intelectuais", Mário de Andrade (1974, p. 49) afirma que:

[...] Nós hoje nos debatemos sofridamente ante os problemas do homem e da sociedade, com uma consciência, com um desejo de solucionar, de conquistar finalidade, com um desespero pela posição de fora-da-lei inerente ao intelectual de verdade, que jamais os artistas do passado brasileiro não tiveram. Basta conceber, por tudo que nos deixaram de obras, de confissões, de vida, como eram fáceis de adaptabilidade, inconscientes de seus problemas individuais e humanos [...]. Hoje estamos preocupados em voltar às nascentes de nós mesmos e da arte [...]. Enfim todos nós estamos conscientes da nossa amarga posição de intelectuais e movidos pelos fantasmas que nascem desse medo. Uma situação maldita.

Segundo Kuhlmann Jr. (2000, p. 185), a preocupação com a infância ganha espaço nos discursos oficiais e nas ações do Estado na "quarta última parte dos anos 1900”. Além disso, diferentes segmentos sociais (políticos, educadores, industriais, médicos, juristas e religiosos) passam a articular associações e espaços voltados para a educação das crianças pequenas. Consequentemente, "o campo educacional fica mais delimitado e a pedagogia passa a ser vista como arte e ciência. Começam a se difundir as ideias de Maria Montessori, que individualizam as crianças e que propõem ao professor se limitar a prestar auxílio, aconselhando".

Na esperança de modernizar o país e seu povo, a educação passou a ser encarada como solução dos problemas e as reformas se espalharam pelos Estados de São Paulo $(1920)^{3}$, Ceará $(1922-23)^{4}$, Bahia $(1928)^{5}$, Minas Gerais $(1927-28)^{6}$, Pernambuco (1928) ${ }^{7}$, Paraná $(1927-28)^{8}$, Rio Grande do Norte $(1925-28)^{9}$ e Distrito Federal (1922 e 1926) ${ }^{10}$. Vale considerar, entretanto, que havia certa diversidade doutrinária entre cada uma delas.

\footnotetext{
${ }^{3}$ Reforma de 1920 em São Paulo: momento em que a necessidade pelo aumento do atendimento educacional público passou a se chocar com a questão da qualidade do trabalho pedagógico. (CAVALIERE, 2003).

${ }^{4}$ Reforma de 1922-23 no Ceará: implantada por Lourenço Filho, seguiu a tendência da renovação pedagógica que estava surgindo no período. (MATE, 2002).

${ }^{5}$ Reforma de 1928 na Bahia: tem início com Anísio Teixeira, que vinha dos Estados Unidos após a realização de um curso com John Dewey. (MATE, 2002).

${ }^{6}$ Reforma de 1927-28 em Minas Gerais: voltado para o ensino primário, foi implantada por Francisco Campos. (MATE, 2002).

${ }^{7}$ Reforma de 1928 em Pernambuco: com Carneiro Leão, tem como principal aspecto a criação do cinema educativo. (MATE, 2002).

${ }^{8}$ Reforma de 1927-28 no Paraná: segue os passos da renovação pedagógica com Lysímaco da Costa. (MATE, 2002).

${ }^{9}$ Reforma de 1925-28 no Rio Grande do Norte: implantada pelo governador José Augusto Bezerra de Medeiros. (MATE, 2002).

${ }^{10}$ Reforma de 1922 e 1926 no Distrito Federal: sob a direção de Fernando de Azevedo, registrou uma mudança na gestão do ensino público, a partir da criação de cargos e de novas divisões administrativas. (PAULILO, 2009).
} 
$\mathrm{Na}$ tentativa de evitar uma dispersão de ideais no campo da educação brasileira, um grupo de intelectuais passou a defender, durante a Era Vargas, a consolidação de um sistema nacional de educação. (BOMENY, 2003). Neste contexto, Manuel Bergström Lourenço Filho $^{11}$ assume a Diretoria Geral do Ensino do Estado de São Paulo e passa a pontuar importantes questões sobre a escola e o Estado: "Há coisas [...] que as crianças têm o direito de aprender, em certa época da vida, e o Estado, obrigação de ensinar pelos mestres que mantém ao serviço da comunidade". (LOURENÇO FILHO, 1930, p. 82).

Marcus Vinicius da Cunha (1995) é enfático ao afirmar que, a partir da década de 1930, o Estado tem não somente a função de promover a educação das crianças, mas, também, definir os conteúdos que deverão ser ensinados e colocar em prática o seu projeto político para as camadas populares através dos professores que o próprio Estado remunera. Sobre este projeto, define que, para Lourenço Filho, a função primordial da escola pública era "servir de núcleo de homogeneização das novas gerações" e que, neste sentido, os professores deveriam atuar como agentes do Estado formando mentalidades cujas bases seriam comuns a todos os sujeitos. (CUNHA, 1995, p. 30).

A criação do Ministério da Educação e Saúde, em 1931, evidenciou a preocupação de Getúlio Vargas com a instrução das camadas populares. Francisco de Campos ${ }^{12}$ assumiu a chefia do Ministério e organiza, no mesmo ano, uma Conferência Nacional de Educação intitulada “As Grandes Diretrizes da Educação Popular”. Neste evento, os principais educadores do país foram chamados para traçarem diretrizes gerais para o ensino público do Brasil - o documento elaborado por Fernando de Azevedo e assinado por 25 educadores recebeu o nome de "Manifesto dos Pioneiros da Educação Nova". (MATE, 2002).

Questionando as bases da escola tradicional, o Manifesto defende uma educação livre dos condicionantes econômicos e sociais, que respeite as necessidades da sociedade como um todo e que seja o instrumento de construção de uma nova nação. Além disso, propunha um programa de ensino considerando que "ainda que mínimo, é necessário: com ele o ensino será direcionado para a obtenção de um determinado tipo de homem, tendo em vista a sociedade que se pretende no futuro". (CUNHA, 1995, p. 41).

\footnotetext{
${ }^{11}$ Lourenço Filho foi um nome importante do cenário educacional do Brasil não apenas pela sua participação na elaboração do Manifesto dos Pioneiros, mas, também, pelos cargos públicos que ocupou: entre 1922 e 1924 foi Diretor da Instrução Pública de Fortaleza, em 1931 foi nomeado por Francisco Campos para ser Diretor de Gabinete, em 1937 foi nomeado Diretor Nacional de Educação por Gustavo Capanema e entre 1938 e 1946 ocupou o cargo de Diretor do INEP (Instituto Nacional de Estudos Pedagógicos). (ABDANUR, 1992).

${ }^{12}$ Francisco de Campos: foi deputado estadual em 1919 e deputado federal em 1921 e 1924. Em 1930 colaborou com a Revolução de Vargas e assumiu a direção do Ministério da Educação e Saúde; em 1937, participou da elaboração da Constituição enquanto ocupava o cargo de Ministro da Justiça. (ABDANUR, 1992).
} 
Cecília Hanna Mate (2002) demonstra que a educação nova, segundo o documento, permitiria que todos os educandos "teriam as mesmas oportunidades, diferenciando-se pelas aptidões [...]. Para isso, os espaços escolares deveriam ser racionalmente organizados de modo a alcançar o máximo de eficiência nos resultados: autodisciplina, autocontrole". (MATE, 2002, p. 140).

Outros aspectos que merecem atenção no que tange as diretrizes da Escola Nova são: a observação às necessidades psicobiológicas dos alunos e a consequente organização de mecanismos que promovam a expansão do potencial criador das crianças, a socialização e a articulação em grupos durante as atividades pedagógicas; a necessidade da formação universitária para os professores - de modo a unificar os princípios educativos; e, por fim, a importância da mobilização das famílias em prol da escola e de seu projeto transformador. (MATE, 2002). A partir deste panorama, Diana Vidal e André Paulilo (2003) consideram que as iniciativas registradas pelo movimento da escolanovista indicam um esforço em prol da renovação da cultura pedagógica dos professores:

Conforme sinalizado anteriormente, a partir do olhar sobre as concepções escolanovistas, pode-se considerar que o projeto de Mário de Andrade para os parques infantis paulistanos contém ressonâncias do espírito de renovação da educação que influenciou o Manifesto. Para que possamos analisar estas ressonâncias, entretanto, é importante explicitar que, conforme Kuhlmann Jr (2000), o próprio documento de 1932 defende a implantação de instituições educacionais e assistenciais às crianças em idade préescolar.

A instituição parqueana, estruturada para receber crianças de 3 a 6 anos em período integral e crianças entre 7 a 12 anos em período oposto à escola regular, tinha, como proposta pedagógica, o reforço à nacionalidade a partir de atividades que promovessem uma imersão das crianças no folclore brasileiro, na produção cultural e artística, nas brincadeiras tradicionais e nos jogos organizados. (KUHLMANN JR, 2000).

Mário de Andrade defendia que a instituição deveria ser encarada como um espaço de integração entre os filhos de imigrantes com a cultural nacional. Por isso, entre os anos de 1935 e 1938, desenvolveu uma série de pesquisas sociais e etnográficas que objetivavam compreender melhor as características da cidade paulistana e buscar soluções, especialmente, para os padrões de vida da população operária. Entre os principais resultados obtidos, o estudo colocou em evidência o grande número de crianças filhas de estrangeiros na cidade (41\% dos núcleos familiares possuíam os dois pais estrangeiros e 19\% possuía um dos pais estrangeiro) e criou um alerta para um conflito que influenciava diretamente o cotidiano das 
crianças que frequentavam a escola: a incompatibilidade entre a cultura familiar e a cultura escolar. "Para que deixassem de ser um "perigo" na construção da nacionalidade, era necessário que estes estrangeiros e seus filhos fossem transformados em paulistas e brasileiros". (RAFFAINI, 2001, p. 54).

Sirlei Silveira (1993), ao analisar a intervenção social operada pelos parques de Mário de Andrade, assinala que a criança adquiriu um lugar privilegiado na política brasileira. Faria (1999a), em consonância com esta ideia, define que os parques, acima de tudo, promoveram uma conquista para o tempo livre de crianças e operários. Nesse sentido, o Ato $\mathrm{n}^{\circ} 767$ reforça o caráter educativo da instituição:

[...] considerando que as atividades lúdicas exercem uma função importante no processo educativo e social, podendo considerar-se os grupos de jogos um dos construtores essenciais da vida social, e a fonte dos primeiros ideais e impulsos sociais, como a solidariedade, a comunicabilidade, a cooperação; [...] considerando que as praças de jogos para crianças, organizadas como meios de preservação social e educação sanitária, têm contribuído eficazmente, em toda a parte, para a educação higiênica e social das crianças, proporcionando-lhes oportunidades e meios de recreação ao ar livre, estreitando o convívio de crianças de todas as classes sociais. (SÃO PAULO, 1935a).

Com isso, pode-se inferir que, posteriormente à "descoberta do Brasil" operada pela década de 1930, ocorreu a descoberta do lazer para as classes operárias a partir do projeto de Mário de Andrade. Ambos os movimentos se constituíram como essenciais no processo de modernização social.

Além da questão do lazer, uma função primordial dos parques era a assistência. Ao tratar deste aspecto, João Pedro Fonseca (1985) apresenta o trecho de um artigo de Miranda (1944) que foi publicado no jornal O Estado de São Paulo em 30 de março de 1944, com o título "Bases científicas da alimentação nos parques infantis":

Os salários dos pais das crianças são muito baixos; a alimentação que a criança recebe no lar é parca e errada; ministrar aulas de educação física, sessões de jogos, atividades motoras, dança, bailado, a crianças desnutridas é ir contra todos os princípios - não é preciso dizer científicos -, mas de simples bom-senso [...]; os parques infantis [...] devem ser centros de prevenção da tubercolose; as condições econômicas, higiênicas e morais que circundam a criança proletária, obrigam todo e qualquer serviço de educação pública a atacar todos os problemas, sem medir esforços ou sacrifícios, enfrentando-os corajosamente, sem rodeios ou preâmbulos. (MIRANDA, 1944 apud FONSECA, J., 1985, p. 145). 
Tal discurso se relaciona com a proposta da eficiência da escola, elaborada pelos escolanovistas. A saúde, a robustez e o vigor físico estão diretamente ligados à produtividade, ao desenvolvimento de aptidões e à formação do cidadão do futuro.

A cientifização da educação que teve início durante a Escola Nova - por influência do modelo norte-americano (BOMENY, 2003) - também se fez presente na rotina dos parques paulistanos: a partir das experiências da instituição, foram realizados estudos acerca da criança, do operariado, da cultura popular, das tradições e do folclore brasileiro. Paulo Duarte (1985) dá indícios da relevância dos trabalhos ali desenvolvidos:

[...] a observação sociológica cientificamente recolhida que iria fornecer ao Serviço de Documentação Social um dos seus melhores elementos para análise, estudos e investigações. À Assembléia Legislativa do Estado, levei, em 1937, um relatório dos benefícios desses recantos de felicidade infantil demonstrando, graças a esses elementos coligidos e estudados por especialistas da Divisão de Documentação Social, que tais observações desprezadas até tempo recente pela escola tradicional e ainda hoje completamente esquecidas da família, se apresentavam sob múltiplos aspectos: um dizendo respeito á saúde física e mental, estimulando a liberdade e a alegria ao ar livre; outro, interessando a coordenação neuromuscular e as funções normais do organismo infantil; outro ainda, a educação da criança, de modo insensível, incutindo-lhe o sentimento da camaradagem, da sociabilidade, da lealdade e da amizade, por meio de atividades lúdicas, como os brinquedos tradicionais do folclore nacional. (DUARTE, 1985, p. 83).

Os profissionais que trabalhavam nos parques (instrutores, educadores e médicos) também desenvolviam pesquisas sobre os mais variados temas: pediculose, hipertrofia de amígdalas, carie dentária, ferimentos, tuberculose, etc. Os resultados destes levantamentos deram origem a melhorias nas condições e na abrangência das ações assistenciais dos parques municipais. (DUARTE, 1985).

Além disso, Mário de Andrade desenvolveu pesquisas relacionadas aos desenhos infantis e é identificado como um dos pioneiros a considerar o desenho como antecipação da escrita pela criança: "Desenhos são pra gente folhear, são pra serem lidos que nem poesias, são haicais, são rubaes, são quadrinhas e sonetos". (ANDRADE, 1975, p. 77).

A preocupação com a mobilização das famílias na educação das crianças levou a instalação de Bibliotecas Populares nos bairros. Com isso, o Departamento de Cultura paulistano pretendia nacionalizar a parcela estrangeira da população, contudo "o grande número de analfabetos era provavelmente um empecilho à concretização do desejo de ver ampliada a prática da leitura e com isto o mercado de livros. A solução seria uma ampla política de alfabetização, tanto da população adulta quanto da infantil”. (RAFFAINI, 2001, p. 
74). Então, na tentativa de facilitar este processo de nacionalização, veículos de comunicação como o cinema e o rádio passaram a ser utilizados para disseminar, entre outras questões, àquelas voltadas para a saúde e a higiene. Entre os projetos que tiveram início durante este período em que Mário de Andrade esteve à frente do Departamento de Cultura, estão as audições públicas com músicas eruditas e folclóricas e as exposições de artes plásticas.

Para que o engajamento em relação aos objetivos de Mário de Andrade fosse efetivo, era necessário, ainda, cuidar da formação dos profissionais que atuavam diretamente com as crianças. Maria Santos (2005, p. 71) define que os parques infantis "foram concebidos dentro dos ideais do escolanovismo, o que, no Brasil, situa sua prática num campo onde não via espaço para professores leigos e os profissionais da educação deveriam ser capacitados e treinados para esse fim".

Para as professoras parqueanas, chamadas de "instrutoras", eram exigidos dois diplomas: um da Escola Normal e outro de algum curso da Universidade (SANTOS, M., 2005). Este dado se confirmou com a pesquisa de Ferreira (2010), onde uma das professoras entrevistadas (que trabalhou em um parque infantil de Ribeirão Preto) afirmou que conseguiu a vaga no parque infantil devido ao seu diploma de Curso Normal e ao seu diploma de Educadora Física.

A preocupação com a qualidade do atendimento às crianças se opõe à ideia de que a instituição criada por Mário de Andrade se limitava à ação assistencialista e reforça a noção de que, neste espaço educativo, se concebia a "criança como um todo". (SANTOS, M., 2005, p. 73) Atribuindo valor a vivência das crianças, o intelectual prezava o espontaneísmo infantil e visava uma educação integral. O Manifesto de 1932, por sua vez, sofreu críticas por defender essa visão global sobre a criança, vinculando educação e saúde e, consequentemente, reconhecendo a dialética existente entre o desenvolvimento e aprendizagem. (FARIA, 1999b).

Sobre o adulto, Mário defendia uma redefinição de seu papel no que tange à educação: ele deveria "observar o inesperado, aprender com ele e construir novos conhecimentos sobre a infância. Afinal, não é só a criança de pouca idade que se transforma, constrói e reconstrói”. (FARIA, 1999b, p. 197).

É importante considerar, portanto, que os Parques Infantis de Mário de Andrade, apesar de apresentarem consonâncias com o ideal escolanovista e apresentarem inspiração em projetos originados em outros países, se constituiu como uma instituição inédita que foi representativa para as políticas de atendimento à infância pobre no Brasil.

No próximo capítulo, chamado Parques infantis: diferentes experiências, serão apresentados os contextos de surgimento e de declínio dos parques infantis paulistanos. Além 
disso, trataremos do surgimento do Departamento de Educação Física de São Paulo e do seu papel de novo artífice de instituições parqueanas no interior do Estado. Neste capítulo, ainda serão cotejados os modelos de Mário e do DEF-SP.

No capítulo 3, intitulado $O$ tempo dos parques infantis em Ribeirão Preto: política e educação, trataremos do contexto da cidade e das demandas que deram origem ao atendimento à criança nos parques infantis que foram instalados na localidade.

O último capítulo, a partir das fontes documentais, trará algumas considerações finais acerca da implantação dos parques na cidade e das mudanças que a instituição provocou em sua sociedade naquele período. 


\section{PARQUES INFANTIS: DIFERENTES EXPERIÊNCIAS}

\section{1 - O Modelo paulistano de Mário de Andrade}

A partir das últimas décadas do século XIX, São Paulo passou por intensas transformações sociais decorrentes do seu processo de industrialização. Segundo Niemeyer, é neste período que os ritmos de vida se modificaram de forma a orientar-se pelas relações estabelecidas pelo trabalho assalariado; além disso, o aparecimento de opções públicas de lazer (cinema, natação, canoagem, jogos esportivos) provocou um conflito relativo à segregação social. Como resultado, a cidade passou a ser dividida: do lado de cá, o "cenário de um urbanismo cívico-embelezador, com suas praças, avenidas e bulevares afinados com um ideal de modernidade importado da Europa", do lado de lá, "o fechado mundo do trabalho, onde vive e trabalha a classe obreira; ambiente disciplinar onde não se permitem pausas para devaneios". (NIEMEYER, 2001, p. 51).

A chave para a alteração desta realidade foi a mobilização do operariado, fortalecida desde o grande movimento grevista de 1917. Joel Santos (1981, p. 22) trata da grandiosidade e dos efeitos deste movimento, que "fez ver às autoridades e aos industriais que a cidade precisava de um esporte de massas" e, além disso, melhorou a tensa relação que se estabelecia entre os operários e a polícia.

Melhoramentos passaram a ser registrados no ambiente de trabalho dos operários, com vistas à atenuação da exploração pelas classes patronais. Vale considerar que, conforme aponta Niemeyer (2001), equipamentos lúdicos instalados no período estavam vinculados muito mais à iniciativa privada do que a uma política governamental pública.

Com a Revolução de 1930, entretanto, o cenário se altera significativamente:

Fundando-se em algum tipo de inclusão dos trabalhadores no jogo político, o populismo getulista terá em mente oferecer a ideia de harmonia social, através de uma política de regulamentação do mercado de trabalho e algum grau de amparo e assistência ao trabalhador. (NIEMEYER, 2001, p. 64).

A Constituição de 1934, em grande parte motivada pelo movimento constitucionalista de 1932, marcou um período de mudanças nas relações entre o Estado de São Paulo e o governo federal. Elizabeth Abdanur (1994) esclarece que, a partir deste momento, a capital paulista passou a ser a peça fundamental do projeto de modernização do governo de Vargas, recebendo um pesado investimento para suas obras de infraestrutura. Para colaborar com este 
movimento, Armando Salles de Oliveira ${ }^{13}$ é nomeado para o cargo de interventor estadual começava aí o rearranjo político do estado, que objetivava uma organização do sistema educacional a partir da articulação das elites intelectuais do período. (ABDANUR, 1994).

O novo governo estadual paulistano, estabilizado politicamente, preservará antigos ideais de dominação política e social, porém dentro de uma nova ótica que compreenderá a necessidade estratégica de fazer "concessões", ao invés de "reprimir", com o desejo de alcançar a paz social, baseada na "harmonia social", e no "congraçamento de classes". (NIEMEYER, 2001, p. 94).

Objetivando manter o prestígio político da capital paulista perante as elites, Salles Oliveira nomeou o engenheiro industrial Fábio da Silva Prado para a prefeitura de São Paulo. O novo prefeito, formado em Engenharia Industrial por uma Escola Politécnica da Bélgica, era sobrinho de Antônio Prado (prefeito paulistano entre 1899 e 1910) e tinha em seu currículo os cargos de direção e presidência de companhias importantes, além de ser membrofundador do Partido Democrático. (ABDANUR, 1992).

Se utilizando de alguns discursos do prefeito publicados na Revista do Arquivo Municipal de São Paulo, Abdanur (1992) nos ajuda a compreender sua posição política:

Como prefeito, Fábio de Prado procurou defender os interesses da burguesia paulista apresentando-os como "interesses de São Paulo". Para isto, utilizouse da idéia de uma "civilização paulista" da qual, segundo ele, teria resultado a "civilização brasileira" para justificar a supremacia dos "interesses de São Paulo" sobre os "interesses nacionais". (ABDANUR, 1992, p. 30).

Para adequar a estrutura funcional da máquina administrativa municipal ao projeto de consolidação da hegemonia paulista, o prefeito iniciou seu mandato fazendo reformas significativas. Visando o aumento da arrecadação de impostos, criou a "taxa de melhoria" e, seguindo uma linha assistencialista, ocupou-se da articulação de uma "força civilizadora", promovendo a difusão da cultura pelo Estado e pelo país. (NIEMEYER, 2001).

A criação do Departamento de Cultura e Recreação, em 1935, deu margem para uma aproximação entre políticos e modernistas. Segundo Luciana Sandroni (1988) a proposta do Departamento foi desenvolvida nas reuniões realizadas no apartamento de Paulo Duarte ${ }^{14}$ (1899-1984) entre os anos de 1926 e 1931, onde os amigos Mário de Andrade, Tácito de

\footnotetext{
${ }^{13}$ Armando Salles de Oliveira foi um engenheiro civil filiado ao Partido Democrático que, apesar de ter sido nomeado como interventor paulista por Getúlio Vargas, tornou-se, mais tarde, opositor do Estado Novo. Chegou a ser exilado mas, na volta ao Brasil (1945) fez parte da fundação da União Democrática Nacional (UDN). (FGV CPDOC, s/d.).

${ }^{14}$ Paulo Duarte foi militante político durante a Revolução de 1930 e, em 1934, foi eleito deputado estadual no Estado de São Paulo. (ABDANUR, 1992).
} 
Almeida, Sérgio Millet, Antônio Carlos Couto de Barros e Rubens Borba de Moraes se encontravam. O próprio Duarte (1985, p. 50) faz um relato acerca dessas reuniões:

Pois foi nessa sala, em tôrno da fria mesa de granito, que um de nós - quem poderá saber qual de nós? - falou na perpetuação daquela roda numa organização brasileira de estudos de coisas brasileiras e de sonhos brasileiros. Mas cadê dinheiro? O nosso capital eram sonhos, mocidade e coragem. Havia quem conhecesse uns homens ricos de São Paulo. Mas homem rico não dá dinheiro para essas loucuras. [...] À vista de tantos argumentos, ficou decidido que um dia seríamos govêrno. Só pra fazer tudo aquilo com dinheiro do govêrno.

Em 1934, convidado para trabalhar na prefeitura, Paulo Duarte levou a Fábio Prado todas as "loucuras" do grupo de modernistas: "Mostrei o primeiro projeto a Fabio Prado. Nunca vi homem de negócios nem homem rico mais acessível às coisas inteligentes. Aprovou tudo, nem pestanejou". (DUARTE, 1985, p. 51).

Segundo Abdanur (1992, p. 46), o prefeito Fábio Prado valorizava o Departamento de Cultura como meio fundamental para "colocar São Paulo numa situação de grande evidência em relação às outras metrópoles". A função deste órgão seria, então, a de promover a "paz social" e a "estabilidade política", conduzindo o Brasil na construção de uma nacionalidade verdadeira.

Para o prefeito, então, a modernização que passava pela cidade de São Paulo deveria ser acompanhada de um aparelhamento cultural, capaz de promover o progresso integral do município.

Em 30 de maio de 1935, o Diário Oficial publicou o Ato $\mathrm{n}^{\circ} 861$ de criação do Departamento Municipal de Cultura e Recreação (SÃO PAULO, 1935b). Entre suas finalidades principais, estavam o estímulo e o desenvolvimento de iniciativas voltadas à educação, à cultura e à arte e a organização de parques infantis, campos de atletismo, piscina e estádios municipais. (SÃO PAULO, 1935b).

Para executar tais funções, sua estrutura contava com cinco divisões: Expansão Cultural, Bibliotecas, Educação e Recreio, Documentação Histórica e Social, Turismo e Divertimentos Públicos. (ABDANUR, 1992).

A Divisão de Expansão Cultural abrigaria a "Seção de Teatro, Cinemas e Salas de Concerto" e a "Seção Rádio-escola" (onde estava anexada a "Discoteca Pública Municipal"); A Divisão das Bibliotecas supervisionaria não só a Biblioteca Municipal, mas também a Biblioteca Infantil, as Bibliotecas Circulantes e as Bibliotecas Circulares - que eram um projeto da prefeitura. Na Divisão de Educação e Recreio havia a divisão entre duas partes: a 
primeira, referente aos Parques Infantis; a segunda, responsável pelos Estádios, Campos de Atletismo e Piscina (chamada de "Seção de Divertimentos Públicos"). Com a Divisão de Documentação Histórica e Social, pretendia-se salvaguardar os materiais existentes no Arquivo Municipal (Sub-divisão de Documentação Histórica) e realizar pesquisas colaborativas com a administração municipal (Sub-divisão de Documentação Social). Por último, destaca-se a Divisão de Turismo e Divertimentos Públicos, responsável não apenas pelas ações promotoras do turismo na cidade, mas, também, pela fiscalização da utilização dos espaços públicos pela população. (ABDANUR, 1992).

Observa-se, portanto, que o alcance do Departamento de Cultura era amplo e, por esse motivo, tão valorizado. Mário de Andrade, idealizador do projeto e entusiasta, revela sua satisfação com o Departamento de Cultura:

A grande cidade, até hoje indestinada em seus tão diferentes destinos, está
por fim consciente da sua maravilhosa predestinação. Estuante de vida
sempre, mas já agora dotada daquela lentidão essencial que desdenha o
egoísmo do presente e arma um futuro que a ninguém pertence, SP de
Piratinga, a mais primorosa criatura dos paulistas, renascida e festiva,
glorifica o Brasil na volúpia de ser dele uma das forças mais perfeitas e uma
das fontes mais fecundas. (ANDRADE, 1935, p. 273).

Em 31 de maio, Mário de Andrade é nomeado chefe da Divisão de Expansão Cultural e diretor do Departamento de Cultura, através da Portaria Municipal no 1.094 de 1934. (ABDANUR, 1992). Sandroni (1988) explicita as razões pelas quais São Paulo entregou o Departamento de Cultura nas mãos não só de Mário de Andrade, mas, também, de outros intelectuais modernistas que escandalizaram a cidade durante a Semana de Arte Moderna de 1922: a derrota de São Paulo no movimento de 1932 fez surgir a necessidade de se resgatar o papel hegemônico do Estado dentro da federação. Junto a isso, passou-se a defender um aperfeiçoamento das elites dirigentes paulistas já que, só assim, as funções públicas seriam mais eficientes.

O comprometimento desses modernistas com a responsabilidade que lhes estava sendo entregue pode ser explicitado pelo excerto retirado de uma Carta de Mário de Andrade em 1935 sobre o Trabalho no Departamento: “é formidável, é gigantesco, é absurdo, tomou minha vida completamente, integralmente, todinha! Desde [...] que tomei posse nada, mas nada absolutamente mais nada fiz do que trabalhar, sonhar, respirar, conversar e viver o Departamento". (ANDRADE, 1983, p. 118).

Além disso, para compreender esta escolha de Mário para a Divisão de Expansão Cultural, é preciso considerar a concepção deste intelectual acerca da criança e da educação e, 
em seguida, faz-se necessário esclarecer a proposta de atendimento infantil que o próprio Mário defendeu.

Vieira (2004) chama atenção para a consciência social de Mário de Andrade e para a defesa da criança brasileira que ele empreendeu. Para o intelectual, a cultura não é apenas consumida, mas, também, produzida pelas crianças. Segundo Faria (1999a, p. 43), Mário foi um dos primeiros a identificar a criança como um "outro completo e dotado de identidade própria".

A criança é essencialmente um ser sensível à procura de expressão. Não possui ainda a inteligência abstraideira completamente formada. A inteligência dela não prevalece e muito menos não alumbra a totalidade da vida sensível. Por isso ela é muito mais expressivamente total que o adulto. Diante duma dor: chora - o que é muito mais expressivo do que abstrair "estou sofrendo". A criança utiliza-se indiferentemente de todos os meios de expressão artística. Emprega a palavra, as batidas do ritmo, cantarola, desenha. Dirão que as tendências dela inda não se afirmaram. Sei. Mas é essa mesma vagueza de tendências que permite pra ela ser mais total. (ANDRADE, 1929 apud ANCONA LOPEZ, 1976, p. 129).

A relação que Mário estabelecia com a infância pode ser percebida em uma de suas cartas destinada a Carlos Drummond de Andrade:

Ora, como eu apesar dos meus trinta anos e mais três já passados inda sou criança que acho uma delícia a gente tocar a campainha dos outros e depois fugir, você pode bem imaginar o divertimento que me dá preocupação e meia vergonha dos que não sabem se sou poeta ou não. (ANDRADE, 1982, p. 47).

Nicanor Miranda (crítico e jornalista do jornal O Diário de São Paulo nos anos 1950) assumiu a Divisão de Educação e Recreios do Departamento de Cultura e, consequentemente, recebeu como missão o fortalecimento da proposta de Parques Infantis. Além disso, Rubens Borba de Moraes ${ }^{15}$ foi encaminhado para a Chefia da Divisão de Bibliotecas e Sérgio Milliet ${ }^{16}$ assumiu a Divisão de Documentação Histórica e Social.

Na concepção dos modernistas, uma nova política permitiria disseminar a cultura, até então limitada aos grupos privilegiados. A idade pré-escolar por sua vez, duramente criticada pelo seu caráter ora elitista, ora assistencialista, passou a ser tema de discussão e chegou a Conferência Nacional de Proteção à Infância, em 1933 - onde foi defendida por Anísio Teixeira (KUHLMANN JR., 2005).

\footnotetext{
${ }^{15}$ Então funcionário da Recebedoria de Rendas do Estado, possuía competência no âmbito das bibliotecas.

${ }^{16} \mathrm{Na}$ época, Sergio Milliet era bibliotecário da Faculdade de Direito. (ABDANUR, 1992).
} 
Para Carolina Costa e Silva (2008), coube a este Departamento e aos intelectuais nele envolvidos, a missão de retomar o poder político que o Estado tinha perdido com a Revolução de 1932. Para tal, o aprimoramento cultural do paulistano foi o instrumento de controle dos conflitos sociais e da neutralização dos possíveis inimigos ao governo.

Os parques infantis, neste contexto, adquirem um caráter essencial para a nova mentalidade instaurada pelo Departamento de Cultura e Recreação: eles surgem para acabar com a massa de crianças e adolescentes que ficavam soltas pelas ruas, vulneráveis ao vício e à criminalidade (FARIA, 1999b). Suas finalidades, publicadas no Ato Municipal nº 767, de 9 de setembro de 1935 (SÃO PAULO, 1935a), são:

a) Zelar pela saúde das crianças, investigar as condições hygiênicas do meio social de que provenham e encaminhar as crianças suspeitas de moléstias ou necessitadas de tratamento aos postos de saúde ou instituições de assistência; b) Attrahir as crianças para os brinquedos próprios à sua idade, desviando-as de todos aquelles que sejam contra-indicados;

c) Orientar as actividades recreativas da criança, velando por ella sem the perturbar ou ameaçar a liberdade e expontaneidade no brinquedo;

d) Ensinar a pratica de jogos infantis, participando com as crianças das atividades lúdicas ou recreativas;

e) Propagar a pratica de brinquedos e jogos nacionais, cuja tradicção as crianças já perderam ou tendem dia a dia a perder;

f) Promover a pratica de todos os jogos que, pela experiência universal, forem dignos de serem incorporados ao patrimônio dos inspirados nas tradições locaes ou nacionaes;

g) Aproveitar as opportunidades proporcionadas pelo interesse das crianças para ministrar-lhes educação physica, sistematizada por meio de exames adequados.

Amparada pelo discurso modernista, uma nova demanda social estava sendo criada: estabelecimentos que atendessem as crianças das camadas populares, oferecendo atividades que contemplassem sua natureza infantil e que, concomitantemente, proporcionasse a defesa de sua saúde e o desenvolvimento de sua intelectualidade. (FARIA, 1999a).

Sobre a questão do atendimento à criança das classes populares, Mário defendia que as instituições não deviam separar a dimensão educativa das dimensões ligadas à cultura e à saúde. Isso significa dizer que o objetivo do atendimento não está relacionado à disciplinarização do operariado, mas, sim ao desenvolvimento de sua capacidade de livre expressão, ao convívio com a diversidade e à construção de uma identidade nacional ${ }^{17}$. (FARIA, 1999a).

\footnotetext{
${ }^{17}$ Cristina Fonseca (2003) demonstra que a consolidação de uma identidade nacional era uma intenção do governo Vargas, que desde meados da década de 1930 se preocupava em manter um domínio político sobre o território brasileiro, caracterizado pela grande diversidade cultural e econômica.
} 
Entre as principais ações de Mário de Andrade, o projeto dos parques infantis (tal como o movimento de instalação do mesmo na cidade) merece destaque devido a sua atuação como protagonista da difusão da cultura brasileira entre as classes populares. Entende-se por "cultura", aqui, o conceito exposto por Raffani (2001, p. 99), onde se refere "aquilo que se vai cultivar". Alfredo Bosi (1987, p. 38) salienta que a noção de cultura corresponde ao "fruto de um trabalho, como algo que dá ao indivíduo consciência, a capacidade de pensar, refletir sobre algo". Assim, Mário de Andrade, preocupado com o "atraso" do Brasil e com a educação pré-escolar, se inseriu na esfera da administração pública, desenvolveu e executou projetos inovadores e articulou mudanças nas condições de vida das classes populares. Vale considerar, entretanto, que este movimento pela educação da classe operária não foi articulado contra a elite, mas, sim, para nivelar a cultura e para torná-la funcional para o desenvolvimento da nação. (VIEIRA, 2004).

Maria Campos (1988, p. 19) indica que esta instituição foi "a primeira iniciativa oficial de maior escala, visando atender as crianças de famílias trabalhadoras da cidade”. Para Santos (2005), o atendimento dos parques infantis se fazia necessário, também, devido à questão da imigração e do crescimento das cidades: “[...] não se pensava em equilibrar ou ampliar as perspectivas sociais da classe operária, mas em exercitar mecanismos que confluíssem para uma homogeneização dos movimentos reivindicatórios" (SANTOS, M., 2005, p. 28).

Niemeyer (2001) explicita os aspectos estruturais e de funcionamento previstos no projeto dos parques infantis paulistanos. Entre os elementos estruturais que menciona, é importante considerar as características do terreno: apesar de não haver uma precisão em relação a metragem do mesmo, destaca-se a necessidade de ser um espaço livre, próximo à escolas e bairros operários - o que demanda planejamento no processo de instalação. Em relação aos elementos de funcionamento do parque, o autor destaca o caráter extra-escolar da instituição, "ou seja, um complemento à educação tradicional oferecida nas escolas da rede normal de ensino"; por fim, destaca alguns aspectos voltados aos profissionais atuantes na instituição: a direção geral da instituição ficava sob a responsabilidade de um higienista que recebia orientações de uma Comissão de técnicos sanitários, os instrutores deveriam ser professores de carreira, formandos em Educação Sanitária (curso oferecido pelo Instituto de Higiene), Educação Física ou com Especialização em Educação Infantil (pelo Instituto de Educação da USP). (NIEMEYER, 2001).

Em quatro anos, o prefeito Fábio Prado inaugurou três parques na cidade de São Paulo (Parque Infantil da Lapa, Parque D. Pedro II, Parque Infantil Santo Amaro) e iniciou a 
construção de outros quatro que foram inaugurados na gestão seguinte - do prefeito Prestes Maia (Tatuapé, Barra Funda, Catumbi e Vila Romana). (NIEMEYER, 2001).

Com o funcionamento dos parques, passaram a ser realizadas pesquisas e observações acerca das condições de saúde das crianças. Faria (1999a) mostra que, em pouco tempo, dados alarmantes fizeram com que a instituição articulasse ações específicas para os principais males que atingiam as crianças: desnutrição, pediculose, gripe, coqueluche, tracoma, amigdalite, coriza aguda, entre outras.

Visando a prevenção de doenças entre as crianças atendidas pelos parques, a alimentação oferecida recebeu reforço, atendendo as indicações feitas por profissionais da Universidade de São Paulo (USP): a merenda passou a ser composta, então, por: leite, pão, manteiga, bananada, goiabada, pessegada, queijo, banana e mel - duas vezes ao dia. (FARIA, 1999a).

Para Zilma de Moraes Oliveira (1992), muitas destas crianças eram filhas dos operários imigrantes da Europa que, em geral, viviam em "moradias insalubres e superlotadas. As crianças destas famílias eram vítimas de frequentes infecções”. (OLIVEIRA, Z., 1992, p. 19).

Segundo Niemeyer (2001, p. 118), os parques atendiam crianças entre 3 e 12 anos de idade durante o dia. No período da noite, o parque recebia a denominação de "Clube dos Menores Operários e/ou Centro das Moças" e se destinava ao lazer de jovens com até 21 anos que já estavam inseridos no mercado de trabalho.

Abdanur (1994) explica que nestas instituições paulistanas o controle de frequência das crianças não era feito de forma rígida: para aqueles pais que tinham o interesse de acompanhar o desenvolvimento dos filhos, era feita uma ficha de inscrição onde, periodicamente, eram anotados dados relativos à altura, peso e doenças; para as demais famílias que não demandavam este tipo de informação, a entrada das crianças era livre e a rotina de atividades também, já que eles mesmos estabeleciam o que gostariam de fazer, escolhendo entre brincadeiras, ginástica, jogos e torneios, desenhos, leituras e artesanato.

Exercícios físicos, jogos e brincadeiras, atividades culturais, artísticas e artesanais foram retratados pelo fotógrafo Benedito Junqueira Duarte entre os anos de 1935 e 1938, como mostra a pesquisa de Silva (2008).

Não se pense, entretanto, que, ali, só se faça brincar, saltar, tomar banho, leite e nada mais. Dependências diversas do pavilhão que é o eixo de toda a atividade do parque, estão destinadas ao estudo, à leitura, ao trabalho de quem quizer estudar, como lêr ou trabalhar. Tudo sem horários, sem os deveres do regime escolar, sem as obrigações de tarefa. Brinquedos diversos 
enchem de alegria as horas dos meninos pobres [...] De fato, para os filhos de operários de São Paulo, são pedaços de céu os Parques que o Departamento de Cultura lhes oferece. (OLIVEIRA, W., 1937, p. 274 apud SILVA, 2008).

Eventualmente, segundo Abdanur (1994), os pequenos participavam de eventos promovidos pelo Departamento de Cultura como, por exemplo, o Congresso Nacional de Língua Cantada, que aconteceu em julho de 1937 (onde apresentaram um "bailado da Marujada") e os concursos de desenho que periodicamente eram organizados e de onde surgiu o interesse de Mário de Andrade pelas produções infantis.

De acordo com Faria (1999a, p. 66), Nicanor Miranda, em um de seus discursos de inauguração de um parque infantil em São Paulo, diferencia a estrutura de funcionamento deste estabelecimento em relação à escola, afirmando que a escola "é o lugar onde a criança deve ficar sentada, bem quietinha, quatro horas por dia e nove meses por ano, absorvendo abstrações e sem a prática da experimentação" e, o parque, em complemento a ela, é o local onde se aprende sobre cooperação e iniciativa, onde se respeita o corpo e onde se harmoniza a relação entre criança e sociedade.

Silva (2008) fez um trabalho de análise das fotografias que foram tiradas nos parques infantis paulistanos na década de 1930, pelo fotógrafo Benedito Junqueira Duarte ${ }^{18}$. Entre as fotos que mais chamam atenção neste trabalho, estão duas que mostram a diferenciação de atividades para meninos e meninas: na primeira, meninas fazem aula de costura e bordado; na segunda, meninos participam de jogos (figuras 1 e 2):

\footnotetext{
${ }^{18}$ Fotógrafo oficial da Prefeitura Municipal de São Paulo. Em relação aos parques infantis, sua missão era dar um toque moderno aos registros, que foram publicados em Álbuns e Revistas da época. (SILVA, 2008).
} 
Figura 1 - Meninas de um parque infantil paulistano em aula de costura e bordado

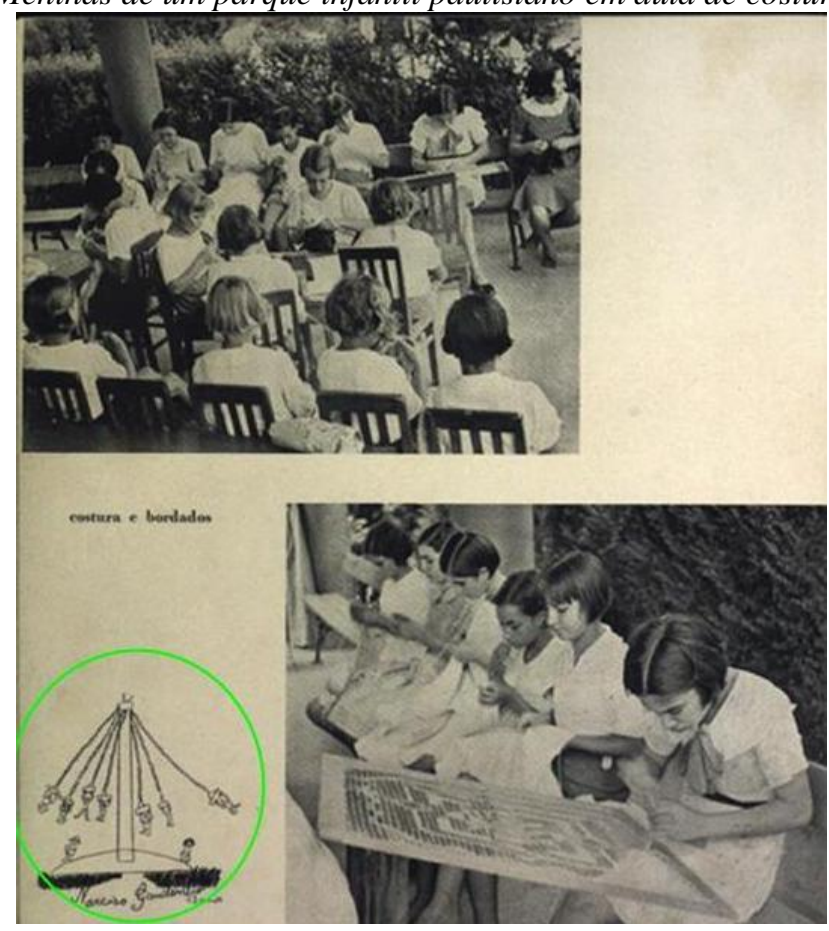

Fonte: SILVA (2008)

Figura 2 - Meninos de um parque infantil paulistano em aula de jogos
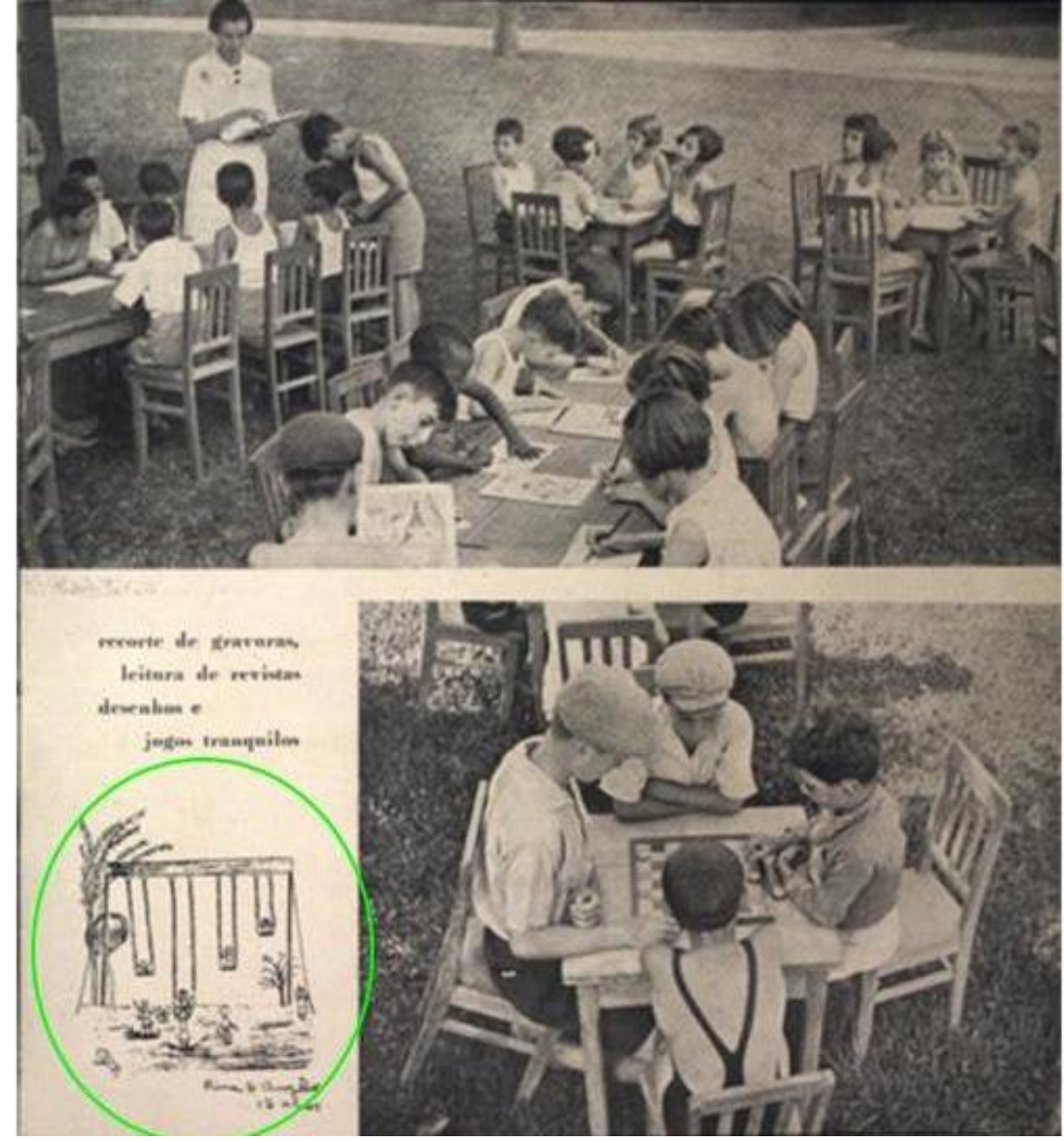

Fonte: SILVA (2008) 
As gravuras posicionadas ao lado das fotos era uma marca registrada de B. J. Duarte. Para Silva (2008), esta era uma forma que o fotografo encontrava de complementar as informações transmitidas pelas imagens.

É importante lembrar, como assinala Niemeyer (2001, p. 111), que os parques instalados em São Paulo na gestão de Fábio Prado, ao contrário da maioria das instituições supracitadas que se assemelham com eles, "não tinham objetivos meramente higiênicos ou disciplinares, apesar de todo o apelo que existia naquela época a esse favor". A preocupação com o desenvolvimento intelectual das crianças parqueanas paulistas diferenciava o projeto de Mário de Andrade dos demais.

Observando a receptividade que o projeto dos parques teve na cidade de São Paulo, a administração municipal elaborou um plano visando a instalação de mais 46 unidades nas regiões mais carentes. O início do Estado Novo, entretanto, inviabilizou a concretização destas obras com o estabelecimento de novas prioridades nas políticas sociais - aos poucos, portanto, a proposta dos parques infantis foi esvaziada. (NIEMEYER, 2001).

Em 30 de abril de 1938, Prestes Maia assume a chefia do executivo paulistano. De imediato, o encaminhamento das políticas públicas é alterado: o novo prefeito rompe com o projeto cultural instaurado pelo Departamento de Cultura e, após seis meses, substitui seu Diretor. (NIEMEYER, 2001).

Em 10 de maio de 1938, Mário de Andrade escreve uma carta para o ministro Gustavo Capanema ${ }^{19}$, contando sobre os rumos do Departamento de Cultura:

[...] As coisas estão se definindo enfim e não parecem muito claras de cor para o Departamento de Cultura. O novo prefeito é um urbanista notável, parece excelente escolha para a cidade. Sob o ponto de vista cultural, departamental, nada consegui apurar por enquanto. Hoje estive com ele para apresentação como de direito de minha demissão, e a conversa não foi nada animadora. Falo em relação ao Departamento, não a mim [...]. Por outro lado, sei de fonte limpa que dos homens do PRP que subiram agora, uma fortíssima corrente deseja a extinção, pura e simplesmente, do Departamento de Cultura. Outra, mais moderada, sustenta a necessidade de sua conservação, acabando-se apenas com certas "brincadeirinhas" inúteis. (SCHWARTZMAN; BOMENY; COSTA; 2000, p. 384).

A partir de 1939, os anos que se seguiram marcaram o início da decadência do projeto idealizado por Mário de Andrade e por um retrocesso no que diz respeito às políticas de atendimento à criança pobre na cidade de São Paulo. Isso porque, já em seu primeiro ano de mandato, o prefeito Prestes Maia indica que sua gestão seria “única e exclusivamente

\footnotetext{
${ }^{19}$ Gustavo Capanema foi ministro da Educação e Saúde Pública na Era Vargas. (ABDANUR, 1992).
} 
técnica", com ações voltadas para a "expansão do projeto industrializante adotado pelo país" (NIEMEYER, 2001, p. 142).

Segundo Niemeyer (2001), ao realizar as inaugurações dos parques Tatuapé, Barra Funda, Catumbi e Vila Romana, Prestes Maia demonstra a negação da concepção inicial de instituição desenvolvida por Mário de Andrade: "o discurso do mandatário municipal revela a sutileza dos meandros do regime em buscar na socialização do corpo, na complacência física dos indivíduos, o "molde plasmador" para uma consciência coletiva obediente e aplicada em seus deveres com a fábrica [...]”. (NIEMEYER, 2001, p. 144).

Em 1940, as políticas públicas de atendimento assistencial para crianças e adolescentes passaram a ser coordenadas pelo Departamento Nacional da Criança (DNCr). Com seu alcance nacional, o DNCr passou a publicar materiais acerca dos parques infantis a partir de uma nova abordagem: a instituição deixava de servir à "formação de consciências" para servir ao propósito de "modelar consciências" infantis de acordo com a necessidade do Estado de disciplinar as massas e preparar o trabalhador nacional "dentro do espírito capitalista”. (NIEMEYER, 2001, p. 146).

Na capital paulista, entre as mudanças observadas no atendimento à criança pobre, tem-se, em 1950, a publicação de um "Programa de melhoramentos públicos para a cidade de São Paulo", também chamado de "Relatório Moses". Tal documento foi elaborado por um urbanista norte-americano (Robert Moses) por encomenda da prefeitura, com o objetivo de melhorar os aspectos do planejamento urbanístico da cidade, melhorando os sistemas de tráfego, transporte coletivo, sanitarismo e obras públicas. Neste relatório, os parques infantis já instalados na cidade foram avaliados como instituições de alto custo e que poderiam ser substituídos por espaços de lazer com atividades menos dirigidas, que abrangessem um número maior de habitantes. (NIEMEYER, 2001). Assim, teve início o movimento de esvaziamento dos parques infantis na cidade de São Paulo.

Segundo Silvana Micaroni (2007), o Decreto-lei Municipal no 3.185 de 1956 que tornou obrigatório o Ensino Primário Municipal colaborou para o enfraquecimento dos parques infantis, já que os recursos financeiros precisariam atender as escolas primárias. De uma forma geral, as famílias operárias passaram a matricular seus filhos na $1^{\text {a }}$ série e, consequentemente, as crianças foram deixando de frequentar os parques. Neste período, a cidade de Ribeirão Preto ainda articulava a inauguração de novos parques infantis, já que o último foi instalado em 1968.

O fim do Estado Novo marca o início de um novo tipo de atendimento à criança pequena. Na nova concepção, a "pré-escola" deve servir como preparação para inserção na 
escola, a estrutura física das instituições destinadas a este fim deve ser simples e a mão de obra envolvida não precisa, necessariamente, receber formação específica (ROSEMBERG, 1992).

Faria (1999a) compara a proposta pedagógica das atuais Escolas Municipais de Educação Infantil (EMEIs) com a antiga proposta dos parques infantis, identificando que nas EMEIs a proposta consiste em enquadrar a criança no modelo escolar tradicional e nos parques, ao contrário, a ideia era criticar a escola da época e oferecer atividades voltadas para o desenvolvimento da capacidade artística, para o estimulo à brincadeira e aos jogos.

\section{2 - A Educação Física e sua influência sobre os parques infantis}

Para compreender o papel da Educação Física nas instituições parqueanas que foram instaladas após a gestão de Fábio Prado na cidade São Paulo e nas demais cidades por onde o projeto foi disseminado, pretende-se, nesta seção, tratar, inicialmente, da preocupação que o século XX registrou em relação à formação do homem completo, ou seja, do homem que carece do desenvolvimento intelectual e, também, do cuidado com o corpo.

Fernando de Azevedo (1960) explicita a concepção de Educação Física que reinava na década de 1920, no estado de São Paulo:

\footnotetext{
Naqueles tempos, já distantes, de minha mocidade, que quase tudo estava por fazer sôbre educação física e nem sequer se havia tomado consciência do que representa essa esfera particular, para a cultura integral da personalidade, no plano nacional de educação. Tudo era indiferença e hesitações, descaso e confusão. Do valor higiênico dos exercícios e da necessidade de lhes estender a prática habitual por todas as escolas; da importância do esforço muscular, indispensável à saúde e à formação da personalidade, pelos seus efeitos biológicos, psicológicos e morais, como por seus efeitos sociais; da apreciação estética do corpo [...] e, quando se animava alguém a enveredar por esses assuntos, era sempre a um pequeno grupo que se dirigia, mais para despertar a consciência do alcance desses problemas do que para analisa-los com rigor e apontar-lhes soluções. (AZEVEDO, 1960, p. 13).
}

Em 1923, o Decreto Federal no 16.300 (BRASIL, 1923) instituiu no interior do já atuante Departamento Nacional de Saúde Pública, a Inspetoria de Higiene Infantil - que, a partir daquele momento, representava a obrigatoriedade da assistência à primeira infância no país. (NIEMEYMER, 2001). 
Com a Revolução de $1930^{20}$, o Brasil passa por um movimento de profunda transformação: com um projeto de modernização, a Era Vargas passa a regulamentar o mercado e articular medidas de amparo e assistência ao trabalhador - o que, consequentemente, reflete na concepção de infância: "A infância torna-se então objeto de um elaborado processo de engenharia social, visando a construção do homem brasileiro e a possibilidade de tornar os menores socialmente 'úteis e produtivos' ao país". (NIEMEYER, 2001, p. 73).

Paulo Ghiraldelli Júnior (2003, p. 16) destaca cinco tendências identificadas por ele no estudo da história da Educação Física brasileira: “a Educação Física Higienista (até 1930); a Educação Física Militarista (1930-1945); a Educação Física Pedagogicista (1945-1964); a Educação Física Competitivista (pós-64); e, finalmente, a Educação Física Popular”.

Em relação à primeira perspectiva, Ghiraldelli Júnior (2003, p. 17) esclarece:

A idéia central é a disseminação de padrões de conduta, forjados pelas elites dirigentes, entre todas as outras classes sociais. A robustez corporal de certa parcela da juventude, robustez advinda de uma vida de poucas privações, é colocada como paradigma para toda a juventude. E os meios para alcançar tal padrão são encontrados na adoção de um correto programa de Educação Física.

Sendo assim, nota-se que, antes de 1930, a educação física e a educação higiênica já eram vistas como fundamentais para a saúde do trabalhador; na busca pela manutenção da força de trabalho surge, então, uma nova bandeira no cenário nacional: "sanear pela educação" (NIEMEYER, 2001).

[...] Aí - nessas cidades industriais e superpovoadas vivem as crianças na promiscuidade das ruas insalubres ou cortiços malsãos, onde, a preço de saúde, se vão os meninos iniciando na vida de tunantes, que o meio fomenta, e na prática de vícios, que o mau exemplo estimula, quando a educação física popularizada, ao alcance de todos, poderia transformar essas pequenas células sociais em preciosos elementos de energia e trabalho. [...] É fácil inferir-se a gravidade deste problema de higiene social, e não há contestar que a educação física poderia contribuir, como fator de primeira ordem, para a sua solução. (AZEVEDO, 1960, p. 207, grifo do autor).

Em 1931, o Decreto Federal no 19.890 (conhecido como Lei Francisco Campos) tornou obrigatória a prática de esportes individuais e coletivos no ensino secundário começa, aí, a regulamentação da Educação Física nos estabelecimentos oficiais. (BRASIL, 1931).

\footnotetext{
${ }^{20}$ A revolução de 1930 tinha como objetivo encerrar com o domínio das oligarquias no comando do país após a crise que atingiu o país em 1929 e a insatisfação popular causada pelas fraudes eleitorais e conflitos regionais.
} 
Vale considerar, ainda, que o papel do Estado em relação ao novo contexto social foi alterado pela Carta Constitucional de 1937 (BRASIL, 1937), escrita no contexto da implantação do parque industrial no país e determinante do que tange a responsabilidade do Estado com o ensino profissional (artigo 129). O objetivo desta determinação era libertar o país da dependência europeia (de mão de obra e produtos industrializados) e promover o desenvolvimento econômico por meio da formação de trabalhadores qualificados para atuar no setor industrial. (CASTELLANI FILHO, 2013). Além disso, destaca-se o Artigo 79 que autoriza e responsabiliza os Estados e municípios a criar departamentos especializados para os seguintes propósitos:

a) promover o amparo dos desvalidos;

b) estimular a educação eugênica;

c) amparar a maternidade e a infância;

d) socorrer as famílias de prole numerosa;

e) proteger a juventude contra toda a exploração, ou abandono físico, moral e intelectual;

f) restringir a mortalidade e a morbidade infantis;

g) impedir a propagação de doenças transmissíveis;

h) cuidar da higiene mental e incentivar a luta contra os venenos sociais;

i) prestar socorros públicos de urgência;

j) animar a iniciativa particular, nas matérias acima referidas. (BRASIL, 1937).

Para tratar da segunda tendência apontada por Ghiraldelli Júnior (2003) no estudo da história da Educação Física, é preciso considerar que a necessidade de fortalecer a nação e afastar a ideologia comunista deu origem, em 1940, a um novo Decreto que criava a Educação Moral e Cívica (constitutiva do modelo de EF Militarista):

Artigo $1^{\circ}$ - A Educação Cívica, Moral e Física é obrigatória para a infância e juventude de todo o país, nos termos do presente Decreto-lei.

Artigo $2^{\circ}$ - A Educação Cívica visará a formação da consciência patriótica. Deverá ser criado, no espírito das crianças e dos jovens, o sentimento de que a cada cidadão cabe uma parcela de responsabilidade pela segurança e pelo engrandecimento da Pátria e de que é dever de cada uma consagrar-se ao seu serviço com maior esforço e dedicação.

[...]

Artigo $3^{\circ}$ - A Educação Moral visará à elevação espiritual da personalidade, para o que buscará incutir nas crianças e nos jovens a confiança do próprio esforço, o hábito da disciplina, o gosto da iniciativa, a perseverança do trabalho e a mais alta dignidade em todas as ações e circunstâncias.

[...]

Artigo $4^{\circ}$ - A Educação Física a ser ministrada de acordo com as condições de cada sexo, por meio da ginástica e dos desportos, terá por objetivo não somente fortalecer a saúde das crianças e dos jovens, tornando-os resistentes a qualquer espécie de invasão mórbida e aptos para os esforços continuados, mas também dar-lhes ao corpo solidez, agilidade e harmonia. (BRASIL, 1940). 
Com o objetivo de formar o "cidadão-soldado", esse modelo de Educação Física objetiva a promoção de uma seleção dos homens mais fortes e, consequentemente, a eliminação dos incapazes. (GHIRALDELLI JÚNIOR, 2003).

Em 1942, a chamada "Reforma Capanema ${ }^{21 "}$ conferiu créditos à Educação Física na tentativa de alterar a mentalidade da classe trabalhadora:

\begin{abstract}
A industrialização consequente da siderurgia impõe aos construtores de todo maquinismo agrícola e rural de trilhos, motores de aviões e armas um mundo material mais humano, a utilização das horas de folga com momentos felizes de reparações, ser sociável para competir com elegância e triunfar com energia. Esta é a nova filosofia de vida e para ela pretendemos orientar a nossa gente pela Educação Física. Ela nos proporcionará um desenvolvimento muscular mais amplo, uma capacidade pulmonar maior, a circulação mais ativa e a função digestiva mais regularizada, em síntese, o equilíbrio orgânico. [...] Nos campos do desporto, devem-se ministrar lições de cooperação e de compreensão ao respeito pelos direitos alheios e à lei, ajustamento ao grupo e a sacrificar-se pelo benefício comum. Eis, senhores, como aspiramos orientar os obreiros da grandeza do Brasil. (ROLIM, 1942, p. 87).
\end{abstract}

Do ponto de vista econômico, a importância da Educação Física era explícita nas legislações nacionais. Do ponto de vista educativo, porém, ganhou espaço após o Estado Novo, no período que Ghiraldelli Júnior (2003, p. 19) chamou de "Educação Física Pedagogicista": “[...] está preocupada com a juventude que frequenta as escolas. A ginástica, a dança, o desporto [...] são instrumentos capazes de levar a juventude a aceitar as regras de convívio democrático e de preparar as novas gerações".

A consolidação de um sistema nacional de Educação Física passa a ser buscada. Aliado a isto, destaca-se o crescimento da rede de ensino pública no país como resultado da mobilização das classes populares nas décadas de 50 e 60 e da democracia populista que se fortalecia no país. Segundo Ghiraldelli Júnior (2003) a caráter da Educação Física no Brasil foi alterado a partir do movimento de expansão da rede pública de ensino já que, enquanto constituinte do currículo escolar, passou a atingir uma clientela cada vez mais ampla: os alunos das camadas assalariadas.

Vê-se, portanto, que o quadro geral da Educação Física no país se modificou bastante, no plano legal, entre os anos de 1920 e 1960. Na tentativa de articular as concepções de Educação Física que se desenvolveram entre as décadas de 1920 e 1960, o estado de São Paulo articulou Secretarias e Divisões de trabalho (com base no supracitado Artigo 79 da Carta Constitucional de 1937), de modo a promover aquilo que inicialmente foi tratado como 
"lazer organizado". Marisa Carpinteiro (1996), em concordância com a nova realidade da Educação Física no país, faz uma reflexão sobre a importância da existência deste lazer para as massas: "a nossa civilização depende muito mais do que fazemos nas horas de recreio e descanso do que daquilo que fazemos nas horas de trabalho". (CARPINTEIRO, 1996, p. 235).

Para que esse lazer fosse promovido, era necessário, inicialmente, promover a proteção das crianças abandonadas, já que estas representavam "caso de polícia" e interferiam na "limpeza" buscada pelos legisladores da cidade. (NIEMEYER, 2001).

\section{3 - O Departamento de Educação Física do Estado de São Paulo}

Em 27 de janeiro de 1931, o Decreto n 4855 cria o Departamento de Educação Física do Estado de São Paulo (SÃO PAULO, 1931). Sobre ele, André Dalben (2009) afirma que as realizações de atividades esportivas eram claramente entendidas como medidas voltadas para o satisfatório desenvolvimento humano - como exemplo disso, o decreto falava em combate ao consumo de bebidas alcoólicas, em meio de se promover a disciplina e a cooperação entre os homens.

[...] difundia-se a idéia de que este problema [do alcoolismo] era de ordem social, atribuído à fatores sociais e raciais, e que poderia ser resolvido, na representação de alguns intelectuais no Brasil, por meio das atividades físicas e esportivas capazes de realizar uma regeneração racial. (MASTROROSA, 2003, p. 124).

Sobre as atribuições do novo Departamento de Educação Física de São Paulo, Ana Carolina Gomes e André Dalben (2010) destacam as funções de "organizar, fiscalizar, incentivar e registrar a prática de esporte no Estado". (GOMES; DALBEN, 2010, p. 322). É importante destacar que, na ocasião de sua criação, o DEF-SP estava vinculado à Secretaria do Interior e que, pouco tempo depois de sua criação, o referido Departamento seria extinto pelo Decreto $\mathrm{n}^{\mathrm{o}} 5.828$ de 4 de fevereiro de 1933. Seus serviços foram transferidos para o Departamento de Educação. A reviravolta e a consolidação do DEF-SP viriam em 1934, enquanto Armando Salles Oliveira ocupava o cargo de Interventor Federal em São Paulo: apresentando justificativas para o retorno do Departamento e definindo suas finalidades, Oliveira conseguiu restabelecê-lo e vinculá-lo à Secretaria da Educação e da Saúde Pública por meio do Decreto $n^{\circ}$ 6440. (MASSUCATO; BARBANTI, 1999).

\footnotetext{
${ }^{21}$ Nome dado ao conjunto de leis ordinárias que visavam regulamentar o artigo 129 da Carta Constitucional de 1937. (BRASIL, 1937).
} 
Adriano Mastrorosa (2003) defende a importância dessas reestruturações administrativas ao salientar que a Educação Física deixou de ser um campo autossuficiente e passou a fazer parte da Educação. Em agosto do mesmo ano, portanto, a regulamentação do DEF-SP fica assim estabelecida (Artigo $1^{\circ}$ ):

- orientar a educação fisica em todos os estabelecimentos de ensino publico, primarios, secundarios, superiores e profissionais;

- organizar e orientar o ensino e a pratica da ginastica e dos esportes nas instituições publicas onde se tornem necessarios ou aconselhaveis;

- fiscalizar e orientar o ensino da ginastica e a pratica esportiva os estabelecimentos de ensino particular;

- organizar uma escola de educação fisica para a formação de professores técnicos; $[\ldots]$

- manter um gabinete técnico e uma bibliotéca especializada para o estudo e demonstração dos problemas da educação fisica;

- estabelecer as condições técnicas para a construção de estadios, campos de recreio e jogos e outros locais de preparação fisica; [...]

- promover, orientar e fiscalizar o controle medico da ginastica e dos esportes: [...]

- organizar e patrocinar provas e demonstrações de ginastica e esportes, assim como concursos de eficiencia fisica nos estabelecimentos públicos; $[\ldots]$

- habilitar candidatos a instrutores ou professores de educação fisica;

- promover a mais ampla e intensa vulgarização da educação fisica. (SÃO PAULO, 1934).

Conforme tais atribuições, nota-se o protagonismo da Educação Física nos estabelecimentos de ensino do período, a preocupação com a formação de profissionais competentes na difusão da mesma, a articulação da prática esportiva com os estudos sobre a área e a vinculação com o controle médico.

Outros artigos do citado decreto merecem destaque e ajudam na compreensão do funcionamento do DEF-SP. Em primeiro lugar, o Artigo $2^{\circ}$ define que o Departamento "poderá solicitar a colaboração de outros serviços públicos" para a realização de suas funções; em segundo lugar, o Artigo $3^{\circ}$ que trata da composição do DEF: Conselho Consultivo, Comissões Esportivas, Secção Administrativa e Secção Técnica; por fim, o Artigo 78 que fala do pessoal: 1 diretor, 1 secretário, 1 inspetor técnico, 2 quartos escriturários, 1 arquivista, 1 fotógrafo, 1 desenhista e 2 serventes. Ao longo do documento, as atribuições são especificadas.

Sobre o Conselho Consultivo, consta que era formado por 7 membros não remunerados - 3 deles indicados pelo Secretário da Educação e da Saúde Pública, 2 especialistas em fisiologia e ortopedia da Faculdade de Medicina de São Paulo, 1 Diretor Geral do Ensino e 1 Diretor do próprio Departamento. Entre as funções deste Conselho, o 
Artigo 10 define: "discutir quaisquer assuntos relativos à educação física, determinando medidas julgadas de utilidade e dar parecer sobre todas as questões para que for solicitado, inclusive sobre os casos de recurso". Nas Comissões Esportivas, seriam elaborados os planos e sugestões para a difusão e o desenvolvimento dos esportes e da ginástica. À Secção Administrativa estava a cargo, entre outras questões, a responsabilidade sobre a "construção dos estádios, campos de recreio e jogos e outros locais de preparação física oficiais e encarregar-se da sua administração geral” (Art. 11). Na Secção Técnica, todos os trabalhos eram supervisionados pelo Inspetor Técnico. São eles:

- organizar o gabinete técnico do Departamento, para estudo e demonstração das questões relativas á educação fisica:

- estudar e estabelecer o padrão minimo de requisitos técnicos a serem exijidos das escolas de educação fisica e locais de torneios, exibições e reuniões esportivas ou de ginastica:

- estudar as condições técnicas para a construção de estadios oficiais, campos de recreio e jogos e outros locais construidos ou adatados para a preparação fisica;

- dar organização técnica às provas e demonstrações de ginastica e esportes, assim como aos concursos de eficiencia fisica promovidos ou patrocinados pelo Departamento;

- estudar os métodos de controle de exercicio fisico promovendo a sua pratica nas associações do ginastica e esportivas:

- estudar e acompanhar o desenvolvimento esportivo do Estado, sugerindo medidas que beneficiem os esportes já existentes ou favoreçam a Implantação de outros julgados uteis;

- estudar as possibilidades da produção nacional do material esportivo, alvitrando medidas que favoreçam o seu desenvolvimento e difusão:

- orientar e fiscalizar a educação fisica nos estabelecimentos oficiais e particulares;

- fiscalizar a pratica esportiva, de conformidade com as determinações da Secção Administrativa;

- fiscalizar o funcionamento das escolas. Institutos ou academias de educação fisica ou destinados exclusivamente ao ensino de determinadas modalidades esportivas;

- dar parecer sobre os casos de habilitação de profissionais formados por instrucções nacionais ou estrangeiras e proceder ao competente registro;

- orientar a pratica da educação fisica nos parques e outros locais publicos. (SÃO PAULO, 1934).

As atribuições do pessoal atuante no Departamento também são claramente definidas no documento. Apresentamos aqui (quadro 1), cada uma delas: 
Quadro 1 - Atribuições dos funcionários do DEF-SP

\begin{tabular}{|c|c|c|}
\hline Cargo & Função & Art \\
\hline \multirow{5}{*}{ Diretor } & - dirigir todo o serviço do Departamento de Educação Física; & \\
\hline & - assinar toda a correspondência oficial; & \\
\hline & - aplicar da melhor maneira a verba de expediente; & \\
\hline & $\begin{array}{l}\text { - administrar, consoante as determinações do Secretario da Educação e da } \\
\text { Saúde Publica, o patrimônio do Departamento de Educação Física; }\end{array}$ & 79 \\
\hline & $\begin{array}{l}\text { - organizar a tabela anual das despesas e requisitar oportunamente, do governo, } \\
\text { as quantias necessárias á manutenção do Departamento de Educação Física e ao } \\
\text { melhoramento dos seus serviços, dentro da respectiva verba orçamentária. }\end{array}$ & \\
\hline \multirow{3}{*}{ Secretário } & $\begin{array}{l}\text { - sistematizar a correspondência e o arquivo do Departamento de Educação } \\
\text { Física; } \\
\text { - adquirir obras e assinar revistas para a biblioteca do Departamento de } \\
\text { Educação Física; }\end{array}$ & \\
\hline & $\begin{array}{l}\text { - sugerir ao Diretor do Departamento as medidas que julgar uteis para o melhor } \\
\text { andamento dos trabalhos de sua secção, comunicando-lhe igualmente as } \\
\text { dificuldades que encontrar no desempenho de suas funções; }\end{array}$ & 80 \\
\hline & $\begin{array}{l}\text { - apresentar ao Diretor do Departamento um relatório mensal dos trabalhos a seu } \\
\text { cargo }\end{array}$ & \\
\hline \multirow[b]{2}{*}{ Inspetor técnico } & - superintender tecnicamente todas as instalações de educação física oficiais; & \\
\hline & $\begin{array}{l}\text { - sugerir ao Diretor do Departamento as medidas que julgar uteis para o melhor } \\
\text { andamento dos trabalhos de sua secção, comunicando-lhe igualmente as } \\
\text { dificuldades que encontrar no desempenho de suas funções }\end{array}$ & \\
\hline Escriturário & - executar todos os trabalhos de escrita & 82 \\
\hline \multirow{2}{*}{ Arquivista } & - classificar os papeis que tenham recebido solução; & \multirow{2}{*}{83} \\
\hline & - guardar e sistematizar o arquivo e a biblioteca & \\
\hline Desenhista & - executar os trabalhos que lhe forem distribuídos & 84 \\
\hline Fotógrafo & - executar os trabalhos que lhe forem distribuídos & 85 \\
\hline Servente & - executar as ordens do Diretor do Departamento e dos chefes das secções & 86 \\
\hline
\end{tabular}

Fonte: produção do próprio autor

O Decreto reflete uma organização muito bem definida e um investimento considerável no âmbito da Educação Física. Dalben (2010) demostra, entretanto, que o DEFSP não atuou diretamente no ambiente escolar, como o previsto. Entre os anos de 1934 e 1939, seu alcance ficou limitado à criação da Escola Superior de Educação Física do Estado de São Paulo (ESEF-SP) e da Associação de Professores de Educação Física do Estado de São Paulo (APEF-SP).

Para montar o corpo docente da ESEF-SP, Fernando de Azevedo articulou, em 1933, uma parceria com a Escola de Educação Física do Exército, que recebeu quinze professores normalistas para um curso. Dos quinze, dez passaram a compor a recém-criada ESEF-SP. Dalben (2010) revela que essa relação com a escola militar foi mantida por muito tempo. 
Em 1935, após a graduação da primeira turma, o então instrutor técnico do DEF, Arne Enge, passou a chamar atenção para a alta demanda de professores especializados na disciplina em detrimento do número reduzido de docentes que a ESEF conseguia formar. Um meio de solucionar o problema seria, segundo ele, a incorporação da disciplina de Educação Física nos Cursos Normais de São Paulo, sob orientação do Departamento. A APEF-SP, em consonância com este propósito, começou a articular uma peregrinação pelas cidades do Estado acompanhada por diversos jornais de alta circulação no período, na tentativa de propagar a importância da Educação Física. Nesses eventos, apoiados pelo DEF, alunos e professores da ESEF estavam sempre presentes. (DALBEN, 2010).

O fortalecimento do Departamento de Educação Física do Estado viria, entretanto, apenas em 1938, por intermédio do interventor federal Dr. Adhemar Pereira de Barros, que aumentou o quadro de funcionários de 10 para 63. Além disso, o Decreto nº 9605 (SÃO PAULO, 1938) instituiu uma nova forma de organização do currículo dos estabelecimentos de ensino paulistas em cumprimento à Constituição de 1937: a partir desta data, o Departamento de Educação Física do Estado torna-se responsável por “dirigir, orientar e fisscalizar" as atividades de educação física não apenas na capital, mas, também, nas cidades do interior.

Vinculado à Secretaria da Educação e Saúde Pública, o órgão teve relação direta com os parques infantis do Estado devido ao Artigo $3^{\circ}$, Parágrafo $1^{\circ}$, que define:

As repartições, serviços avulsos ou secções já existentes na administração estadual ou municipal cujas atividades compreendam a educação física sob qualquer dos seus aspectos articular-se-ão com o Departamento de Educação Física, para perfeita coordenação de trabalho, orientação e pesquisas. (SÃO PAULO, 1938).

Essa coordenação seria, segundo o Decreto, firmada por meio das Inspetorias Regionais de Educação Física, instaladas em diferentes cidades do Estado.

Para compreender a relação do Departamento de Educação Física com os parques infantis, é necessário analisar a publicação de 30 de maio de 1939, o Decreto no 10243 (SÃO PAULO, 1939): inicialmente, o Artigo $2^{\circ}$ estreitou as relações entre DEF-SP e Prefeituras Municipais ("todos os municípios será instalada uma comissão do Departamento de Educação Física, sob a presidência do Prefeito Municipal, com as funções de organizar e dirigir, conforme as diretrizes gerais fixadas, os núcleos locais”) e, no Artigo $8^{\circ}$, foi criado o cargo de “inspetor geral dos Serviços de Parques Infantis", subordinado ao Diretor Geral do DEF. 
Uma notícia publicada no jornal Correio Paulistano ${ }^{22}$ em 1939 mostra a forma como o conteúdo do Decreto foi divulgado:

Para o maior desenvolvimento da educação physica no interior do Estado, em decreto hontem submetido á assinatura do sr. Interventor Federal, acabam de ser fixadas novas diretrizes para a atividade do Departamento de Educação Physica.

O decreto em apreço prevê a creação de uma comissão do referido Departamento em cada município, sob a presidência do referido prefeito, estabelecendo, ainda, medidas sobre a construção de "play-grounds" em todas as cidades do interior.

[...] Segundo informações obtidas pela nossa reportagem, será creado, também, o cargo de inspector geral do Departamento de Educação Physica com as atribuições de fiscalizar o exacto cumprimento dessas novas medidas em todo o Estado. (CORREIO PAULISTANO, 1939).

Até o ano de 1942, segundo Dalben (2009), já haviam sido instaladas dez Inspetorias Regionais em cidades do Estado de São Paulo, quais sejam: Campinas, Guaratinguetá, Sorocaba, Santos, Catanduva, Ribeirão Preto, São Carlos, Avaré, Botucatu e Bauru.

O Relatório de Atividades do Departamento de Educação Física do Estado de São Paulo de $1942^{23}$ também publicou um Artigo tratando do controle, inspeção e orientação que o Departamento vinha realizando desde 1939 em relação aos parques do interior. Segundo este documento, fica explícito o fato de que a instituição parqueana era representativa no programa de educação integral. Os benefícios dos parques são vistos como "deveras lisongeiros", já que servem como "uma escola de civismo, patriotismo e ensinamentos práticos de nossa infância”. (DEPARTAMENTO DE EDUCAÇÃO FÍSICA DE SÃO PAULO, 1942, p. 23).

Para o DEF-SP, a atividade física era um aspecto-chave na formação da criança. Através de jogos livres, jogos organizados, exercícios físicos, atividades ritmadas, aulas natação e de dança, dramatização, musicalização, trabalhos manuais (marcenaria, modelagem, bordado e costura), palestras, festivais, excursões e contações de história, a rotina no parque era delineada. “[...] O Parque Infantil deve ser, portanto, um lugar aprazível, com espaço para correr e saltar, cheio de distrações, onde a criança sinta desejos de permanecer o maior tempo possível”. (DEPARTAMENTO DE EDUCAÇÃO FÍSICA DE SÃO PAULO, 1950, p. 1). O que está implícito no conceito de parque proposto pelo DEF-SP é o afastamento da concepção de criança e de desenvolvimento integral (centrado nas brincadeiras infantis e no conhecimento/produção da cultura nacional) defendido por Mário de Andrade - o modelo do

\footnotetext{
${ }^{22}$ Este jornal não fez parte do escopo da pesquisa, mas a matéria citada aqui foi encontrada em meio aos documentos oficiais dos Parques de Ribeirão Preto e, pelo seu conteúdo, merece constar no presente trabalho.

${ }^{23} \mathrm{O}$ documento pode ser encontrado no Centro de Memória da Unicamp no Fundo Otília Foster.
} 
DEF, apoiado na educação física como atividade principal da instituição, empobrece o projeto inicial originado na década de 1930.

Gomes e Dalben (2011, p. 322) definem as principais funções do Departamento de Educação Física do Estado de São Paulo como sendo "organizar, fiscalizar, incentivar e registrar a prática dos esportes no estado". A justificativa desta intervenção está na concepção moderna que o Brasil passa a adotar em relação ao "ambiente ideal" - a vida na natureza é colocada como facilitadora para o fortalecimento do corpo e para a cura e prevenção de doenças. Por isso, a ação do Estado sobre os parques infantis foi tão marcante neste período. Nesta instituição, o exercício físico seria a chave para a formação do homem saudável (DALBEN, 2009).

Em relação aos profissionais atuantes na instituição, o Departamento indicava a necessidade de educadores preparados para o acompanhamento das atividades desenvolvidas na instituição (jogos, exercícios físicos, trabalhos manuais artísticos, excursões) e, além disso, de profissionais ligados à área da saúde que deveriam realizar os atendimentos médico, dentário e, além disso, orientar a rotina alimentar das crianças.

Do ponto de vista da estrutura física dos parques, o DEF-SP era o responsável pelas sugestões para a escolha do terreno, pela elaboração das plantas do pavilhão, pela organização espacial dos equipamentos de lazer e dos móveis, pelo material de Educação Física a ser adotado, tal como pelos jogos e os livros a serem adquiridos pelas instituições. (DALBEN, 2009).

Com essas medidas administrativas, o DEF-SP foi se consolidando enquanto mobilizador de gestões municipais em prol da instalação de parques infantis. Por meio de documentos encontrados no Arquivo Público e Municipal de Ribeirão Preto, nota-se que as definições que orientaram as primeiras instituições da cidade (plantas, projetos arquitetônicos, equipamentos de lazer) foram enviadas pelo Departamento e avaliadas/concretizadas pela prefeitura municipal.

O Relatório de Atividades do Departamento de Educação Física de São Paulo, em 1942, publicou um artigo sobre o parque infantil de Araraquara com o seguinte adendo:

O Departamento de Educação Física do Estado de São Paulo tem procurado por todos os meios intensificar o movimento de construção de parques infantis no Interior do Estado. Aproximando-se a época da entrega dos orçamentos municipais, este Serviço enviou a todas as prefeituras uma publicação sobre o serviço e utilidades dos Parques Infantis, Colônia de Férias e Escola de Aplicação ao Ar Livre, acompanhada por uma circular sugerindo aos prefeitos a inclusão de uma verba destinada aos parques infantis. Muitos prefeitos apressaram-se a responder pedindo sugestões e 
informações a respeito do assunto. Além disso, através de sua Inspetoria, o DEF procura estar em contato com as Prefeituras a-fim-de interessa-las nessa iniciativa. Para as cidades onde já funcionam parques infantis, tem sido solicitadas publicações sobre Educação Infantil ou outras de interesse da criança. (DEPARTAMENTO DE EDUCAÇÃO FÍSICA DE SÃO PAULO, 1942, p. 25).

O investimento em parques infantis no interior de São Paulo se constitui, então, como uma função do Departamento de Educação Física. As bases deste investimento e a forma como o novo paradigma influenciou na oferta de educação infantil nas cidades estão explícitas na próxima seção.

\section{4 - Parques infantis disseminados pelo Departamento de Educação Física no interior paulista}

O Relatório de Atividades do Departamento de Educação Física do Estado de São Paulo divulgou, em 1942, que, além das instituições de Campinas e Araraquara (já em pleno funcionamento), o Parque Infantil de Santos já estava concluído e que os parques de Pirajuí, Piracicaba e Pinhal estavam com suas obras em andamento. Além disso, explicita que, por "intermédio deste Departamento", os projetos de parques para as cidades de Amparo, Jundiaí, Ribeirão Preto, Catanduva, Jaboticabal, Monte Alto, São José dos Campos, Itatiba, Pirassununga, Serra Negra, Itapira, São Carlos, Barretos, Mogi-Mirim, Santo André e Mogi das Cruzes estavam prontos - e não tinham sido iniciados devido "as dificuldades que o país atravessa com a situação internacional”. (DEPARTAMENTO DE EDUCAÇÃO FÍSICA DE SÃO PAULO, 1942, p. 23).

Até 1952, já haviam sido construídos parques infantis em 15 cidades do interior de São Paulo, entre elas: Araraquara, Santos, Marilia, Pinhal, Campinas, Jundiaí, Ibitinga, Pirajuí, Piracicaba, Itu, Mogi das Cruzes, Tremembé, São Vicente, Franco da Rocha e Ribeirão Preto. Segundo uma publicação datada em 7 de maio de 1959 no Diário Oficial (BRASIL, 1959), o interior do estado já possuía naquele momento 45 parques infantis, tamanha a intensidade de trabalho do Departamento de Educação Física do Estado.

Em Campinas, a criação do primeiro parque infantil ocorreu em 1940 - período em que a atividade industrial começava a se desenvolver. A instituição, localizada no bairro do Cambuí foi denominada "Violeta Dória Lins" em 1950 e, segundo dados encontrados nos Relatórios do município e citados por Michelle Teodoro (2005), possuía: 
[...] um salão central, ladeado por salas para biblioteca, médico, dentista, professores, copa, cozinha, instalações sanitárias e chuveiros, para os dois sexos [...], piscina, com dimensões retangulares, palco ao ar livre, campos para ginástica, bola ao cesto, vedação do terreno, terraplanagem geral, arborização e mais serviços complementares (CAMPINAS, 1943 apud TEODORO, 2005, p. 13).

A rápida expansão da industrialização e o sucesso do primeiro parque infantil da cidade de Campinas fez com que, logo em 1942, fosse inaugurado um segundo parque, chamado de "Celisa Cardoso do Amaral". Segundo uma ex-diretora do Parque Violeta Dória Lins, na ocasião da instalação dos parques de Campinas, as orientações foram passadas pela própria prefeitura de São Paulo, já que o Departamento de Educação ainda não estava em funcionamento - tal depoimento aparece na pesquisa de Moysés Kuhlmann Jr. e Maria Martha Silvestre Ramos (2001).

As instalações de ambos os parques campineiros eram idênticas, segundo Teodoro (2005): “a estrutura física desses dois PIs se fundamentava claramente na proposta do Plano de Melhoramentos Urbanos, de Prestes Maia, pois eles eram construídos em áreas amplas e arborizadas, ressaltando a importância das atividades físicas e desportivas" (TEODORO, 2005, p. 14).

Com o passar dos anos, a necessidade de novas áreas de atendimento à criança deu origem a um outro tipo de instituição em Campinas: os Recantos Infantis. Menos onerosos para a prefeitura, apresentavam um espaço físico e um quadro de funcionários reduzidos em relação aos parques. Além disso, recebiam apenas crianças entre quatro e dez anos (enquanto os parques recebiam crianças entre três e doze anos). $\mathrm{O}$ aspecto comum entre as instituições era, entretanto, a valorização da Educação Física: “a Educação Física nos Parques e Recantos ocorria principalmente através de jogos motores organizados, prática de brinquedos, jogos nacionais, iniciação desportiva e ginástica sistematizada”. (TEODORO, 2005, p. 27).

Em 1955, as transformações políticas, econômicas e sociais registradas em Campinas deram origem a um "Plano Municipal de Ensino, Cultura e Recreação" que salientou, entre outras questões, a necessidade de se criar novos Parques e Recantos Infantis. Por esse motivo, entre 1958 e 1959, foram inaugurados oito Parques Infantis - que levaram a cidade a contabilizar, em 1960, dez parques e quatro recantos. Segundo Teodoro (2005), em 1980, Campinas totalizou dezenove parques infantis.

Mônica Pereira (2008) trata do Parque Infantil "Leonor Mendes de Barros", fundado na cidade de Araraquara no ano de 1941. Segundo a autora, o nome do parque foi escolhido em homenagem à esposa do então Interventor Federal Adhemar Pereira de Barros e as 
orientações relativas ao seu funcionamento estavam a cargo do Departamento de Educação Física do Estado de São Paulo. Além disso, Pereira (2008) revela que as turmas eram compostas por crianças de diferentes idades (de 3 a 12 anos) e que "no ato da matrícula, as crianças já recebiam um número, com o qual eram identificadas durante a sua permanência na unidade”. (PEREIRA, 2008, p. 33).

O Relatório de Atividades do Departamento de Educação Física do Estado de São Paulo de 1942 explicou que a baixa frequência registrada neste parque infantil se justificava pelo fato de haver apenas uma professora designada para aquela instituição. Mesmo assim, a obra era divulgada como sendo "uma das realizações de maior alcance na consecução das diretrizes traçadas para um programa de educação integral". (DEPARTAMENTO DE EDUCAÇÃO FÍSICA DE SÃO PAULO, 1942, p. 24).

Na figura 3, retirada do Relatório de 1942, crianças realizam uma apresentação artística em dia de festa:

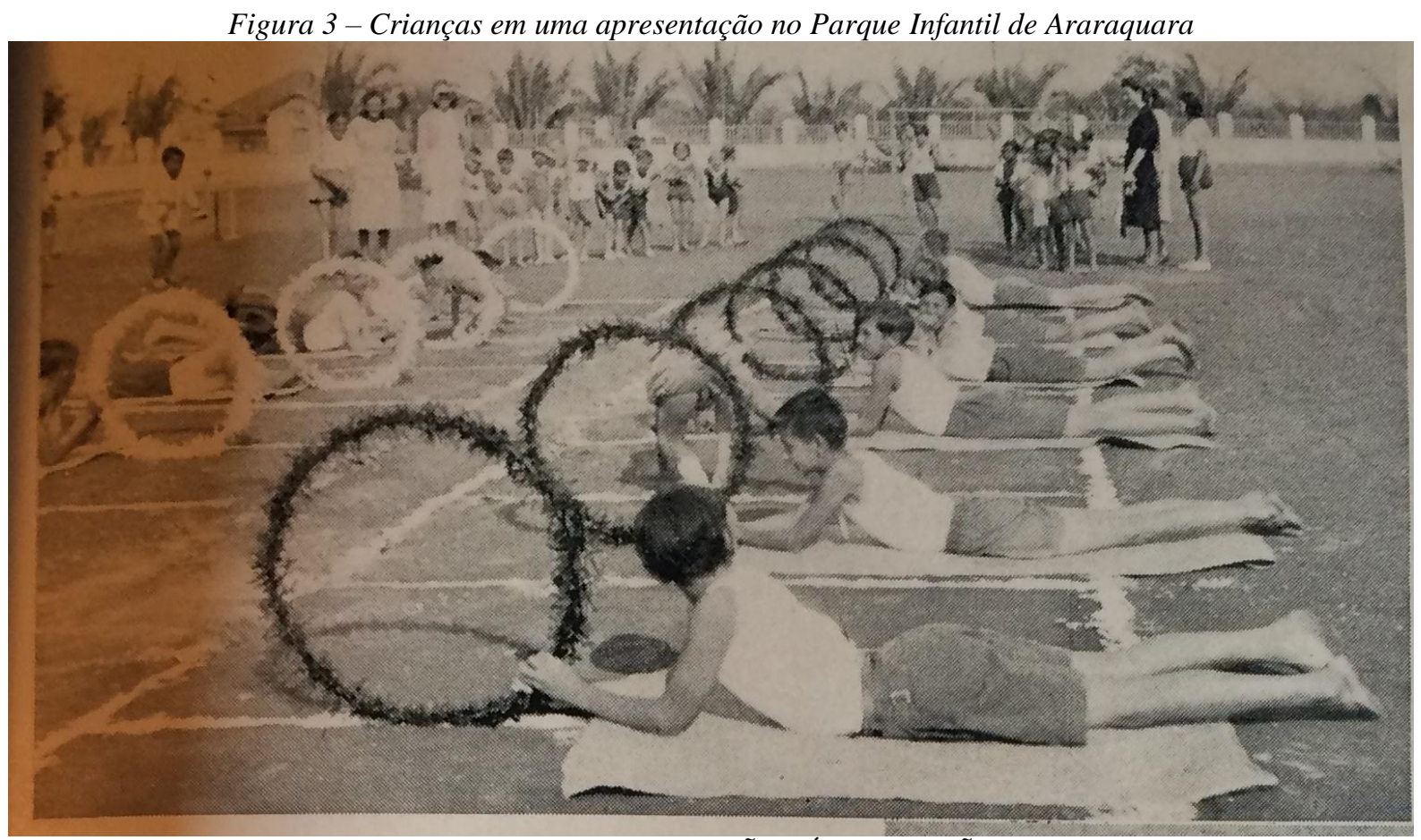

Fonte: DEPARTAMENTO DE EDUCAÇÃO FÍSICA DE SÃO PAULO (1942)

Vale considerar ainda que, conforme o trabalho de Pereira (2008), o segundo parque infantil de Araraquara foi inaugurado em 1951 e o terceiro, em 1969.

Em 1954, foi a vez de Sorocaba inaugurar o seu primeiro parque infantil. A obra fez parte das comemorações do terceiro centenário da cidade que, em processo de franca expansão, recebia muitos imigrantes desde meados dos anos 20. Suad Oliveira (2010) define 
que o processo de implantação da unidade teve início devido à iniciativa de um jovem de apenas 19 anos que, durante o curso de Educação Física na Universidade de São Paulo, visitou os parques paulistanos e, interessado, levou a ideia para Sorocaba.

Assim, a campanha foi iniciada por meio de mensagens em rodapés do jornal Cruzeiro do Sul, em 1953. Eram frases que alertavam as autoridades e a população sobre a necessidade e os benefícios que os parques trariam principalmente aos bairros, solucionando um problema social que, na época, tendia a se ampliar. (OLIVEIRA, S., 2010, p. 57).

Denominado "Antônio Carlos de Barros", o parque infantil de Sorocaba atendia 500 crianças entre 3 e 12 anos e possuía uma estrutura física semelhante àquela indicada pelo DEF-SP: "salas amplas, canteiro com flores, playground, piscina, tanque de areia, casinha de bonecas, diretora, professor de Educação Física, professoras recreacionistas, servente, cozinheiras e atendimento médico e odontológico permanente”. (OLIVEIRA, S., 2010, p. 57).

Os professores do parque "Antônio Carlos de Barros" realizaram cursos de recreação infantil ministrados por representantes do DEF-SP, que periodicamente iam à Sorocaba acompanhar o funcionamento da instituição. Ainda segundo Suad Oliveira (2010), a educação física era orientada pelos médicos dos parques e objetivava, principalmente, promover a afetividade entre as crianças e a "educação moral deveria incutir na criança o conceito de comportamento social, o sentido de justiça e lealdade, a noção de dever no parque, na escola, no lar e na sociedade". (OLIVEIRA, S., 2010, p. 57).

Americana foi mais uma cidade a inaugurar uma instituição parqueana. Em 1969, o Decreto municipal $\mathrm{n}^{\circ} 443$ (AMERICANA, 1969) regulamentou que a matrícula seria realizada somente para as crianças entre 4 e 6 anos de idade que apresentassem "condições satisfatórias de saúde". Já o Decreto municipal no 647, de 10 de dezembro de 1973 (AMERICANA, 1973) explicita que a principal finalidade do parque é o atendimento de crianças "carentes" cujos pais trabalham. Segundo o trabalho de Edvania Guimarães (1999), o único indício de que a Educação Física era parte integrante do currículo do parque era o Artigo 20 do supra-citado Decreto $\mathrm{n}^{\circ}$ 647, que elencou as atividades desenvolvidas na instituição: "jogos sensoriais e de inteligência, exercícios de educação física e jogos infantis, aulas de canto e organização de corais, danças folclóricas, exercícios de coordenação motora e aula de educação moral e religiosa". (GUIMARÃES, 1999, p, 22).

Ao que parece o modelo de parque instalado em Americana não corresponde com as orientações do DEF-SP. Uma hipótese para esta incongruência seria o fato de que a instalação da instituição naquela cidade se deu tardiamente, num período em que o Departamento já não 
exercia tanta influência junto às prefeituras municipais no fomento e manutenção de novos parques.

Poucas pesquisas acadêmicas sobre estes parques infantis foram publicadas, ou, ainda, contemplaram os diversos casos de parques nas cidades paulistas que os receberam. No interior de São Paulo, as únicas cidades que já registram estudos sobre os seus parques infantis são Campinas, Araraquara, Sorocaba e Americana. Sobre as demais, fica a necessidade de estudos mais aprofundados para a construção da história do atendimento à criança no Estado. 


\section{O TEMPO DOS PARQUES INFANTIS EM RIBEIRÃO PRETO: POLÍTICA E EDUCAÇÃO}

\section{1 - Alguns apontamentos sobre a política municipal no período de surgimento dos parques infantis}

No plano político, a primeira metade do século XX em Ribeirão Preto foi marcada por mudanças no processo de escolha dos dirigentes municipais. Em 1930, a Câmara - até então responsável pelas eleições - é dissolvida e os prefeitos, então, passaram a ser nomeados por interventores federais do estado de São Paulo. Os últimos prefeitos nomeados nestes moldes foram Rubem Aloísio Moreira e Jarbas Vieira de Souza, que atuaram no ano de 1947. (RIBEIRÃO PRETO, 2000).

A partir de 1948, as eleições na cidade passaram a acontecer pelo voto popular, ou seja, prefeitos e vereadores começaram a ser escolhidos por eleições. Era o início do regime democrático que vigora até os dias de hoje no município. Abaixo, o quadro 2 com os prefeitos que atuaram até 1979 - ano de inauguração do último parque infantil da cidade:

Quadro 2 - Prefeitos de Ribeirão Preto entre 1947 e $1981^{24}$

\begin{tabular}{|c|c|}
\hline Período & Prefeito \\
\hline 1947 & Rubem Aloysio Monteiro Moreira \\
\hline $\mathbf{1 9 4 8 - 1 9 5 1}$ & Jarbas Vieira de Souza \\
\hline $\mathbf{1 9 5 2 - 1 9 5 5}$ & José de Magalhães \\
\hline $\mathbf{1 9 5 5 - 1 9 5 9}$ & Costábile Romano (mandato concluído por Áureo Norberto da Silva) \\
\hline $\mathbf{1 9 6 0 - 1 9 6 4}$ & Alfredo Condeixa Filho \\
\hline $\mathbf{1 9 6 4 - 1 9 6 9}$ & Welson Gasparini \\
\hline $\mathbf{1 9 6 9 - 1 9 7 3}$ & Antônio Duarte Nogueira \\
\hline $\mathbf{1 9 7 3 - 1 9 7 7}$ & Welson Gasparini \\
\hline $\mathbf{1 9 7 7 - 1 9 8 1}$ & Antônio Duarte Nogueira \\
\hline
\end{tabular}

Fonte: produção do próprio autor

Embora Ribeirão Preto comece a despontar no cenário nacional com o desenvolvimento da economia cafeeira a partir do final do século XIX, é sobretudo a partir da década de 1950, quando se intensificou o processo de recuperação econômica após a crise dos

\footnotetext{
${ }^{24}$ ARQUIVO PÚBLICO E HISTÓRICO DE RIBEIRÃO PRETO. História de Ribeirão Preto. Disponível em: <http://www.arquivopublico.ribeiraopreto.sp.gov.br/scultura/arqpublico/i14index.php?pagina=/scultura/arqpubli co/historia/i14indice.htm>. Acesso em: 20 mar. 2015.
} 
anos trinta, que o município avançou com maior celeridade em direção aos elevados padrões de riqueza que a caracterizam e por meio da qual ele se tornou conhecido em todo o país. (PIRES, 2004, p. 179).

Para que possamos analisar o contexto municipal no recorte temporal da presente pesquisa, vamos realizar um balanço da repercussão dos temas da infância e da necessidade de assistência aos pobres pela via escolar, tomando como protagonista as ações do poder público.

Prandi (2015, p. 132) demonstra como a imagem dos parques infantis estava atrelada às imagens das autoridades políticas locais:

[...] a disseminação de uma boa imagem pública de uma instituição como o parque infantil também promovia as políticas públicas locais de educação, cultura e higiene realizadas pelas administrações municipais, resultando também numa boa imagem pública dos próprios políticos, ou seja, numa forma de propaganda política. Se divulgada uma imagem negativa dos parques, a mesma negatividade cairia sobre aquelas administrações.

O ano de 1947 constitui o último ano em que o cargo de Prefeito Municipal foi ocupado por meio da nomeação do interventor estadual. Rubem Aloysio Moreira iniciou seu mandato em 17 de março; Jarbas Vieira de Souza foi se sucessor a partir de 28 de novembro e permaneceu no comando do município até 29 de dezembro.

Os primeiros contatos registrados entre a prefeitura e o DEF-SP, conforme consta anteriormente, foram estabelecidos com Rubem Aloysio Moreira. Analisando os ofícios supracitados, tem-se a impressão de que este prefeito demonstrou abertura em relação à proposta dos parques infantis e, apesar de não ter realizado a implantação desta instituição, aparece nos documentos municipais como responsável por outras ações de importância para a cidade, tais como o combate ás fraudes da economia popular, a reconstrução de $320 \mathrm{~km}$ de estradas municipais, a construção do Pronto Socorro Municipal, o início das obras para instalação do serviço de telefone automático na cidade e a articulação da assistência médica extensiva aos trabalhadores rurais.

A investigação do contexto da cidade no ano de 1947 foi realizada por meio do jornal Diário da Manhã e em 19 de outubro de mesmo ano mostra que o problema da infância já era colocado como questão a ser resolvida de maneira urgente pelos homens do governo e aparecia como promessa de governo nas campanhas para prefeitura que foram publicadas no jornal ("Costabile acabará com isso!" é o título de uma nota que defende a candidatura de um prefeito, em 19 de outubro): 
[...] Mas um candidato como Costabile poderá, sem sombra de dúvida, pelo menos fazer algo por essa infância que vive tão abandonada. [...] Os estabelecimentos educacionais merecem toda a atenção dos homens de governo. [...] Crianças brincando inocentemente com o perigo, com pés e mãos metidos na lama e no lodo, não têm culpa alguma. Seus pais também não, porque, no trabalho, não podem fazer com que seus filhos vivam dentro de quatro paredes. A culpa cabe única e exclusivamente aos politiqueiros. Aos homens que, governando, se esquecem de que existe povo. (DIÁRIO DA MANHÃ, 1947).

Jarbas Vieira ocupou a prefeitura apenas pelo mês de dezembro de 1947. No Arquivo Público Municipal não foi encontrado nenhum ofício assinado por ele. Uma notícia deste período, entretanto, indica a atuação do Departamento de Educação Física do Estado de São Paulo na formação dos professores municipais: trata-se de um comunicado sobre a elaboração de um "Curso Rápido de Orientação de Educação Física”, com duração de três meses, para os professores primários efetivos pela Diretoria do DEF-SP, de acordo com o jornal Diário da Manhã de 10 de dezembro de 1947.

Em 1948, José de Magalhães torna-se o primeiro prefeito eleito da cidade de Ribeirão Preto depois do fim do Estado Novo. Apesar de ser natural do Rio de Janeiro, sua força política junto à população ribeirão-pretana se explica pelo fato de que, antes da candidatura, esteve presente em diversos setores sociais da cidade, exercendo funções de liderança. Magalhães diplomou-se em Direito no ano de 1927 pela Universidade do Brasil (Rio de Janeiro) e, nesse período, exerceu a função de examinador no Colégio São José de Batatais o que provocou sua aproximação com o interior do Estado de São Paulo. Em Olímpia, exerceu a advocacia e, em 1928, foi nomeado Delegado de Polícia na cidade de Guará (que fica a cerca de $90 \mathrm{~km}$ de Ribeirão Preto). Sempre esteve à frente de ações na área da educação: fundou o Colégio Taquaritinga, o Ginásio Guaraense e o Ginásio Olimpiense. A transferência para Ribeirão Preto se deu em 1932, quando voltou a advogar e exerceu o magistério na Instituição Moura Lacerda, no Ginásio Progresso, no Ginásio do Estado e na Escola de Comércio Pedro II. Foi diretor Pedagógico na Escola Senac e professor assistente da Universidade do $\mathrm{Ar}^{25}$, destinada a elevar o nível cultural dos comerciários. Além disso, foi presidente do Botafogo Futebol Clube, da Associação Portuguesa de Esportes Atléticos, da Liga Regional de Futebol e membro da Comissão Central de Esportes. Foi também diretor e orador oficial da Sociedade Legião Brasileira de Cultura e Civismo, membro da Academia Ribeirão-pretana de Letras, presidente da Junta de Conciliação e Julgamento de Ribeirão Preto e consultor jurídico da ACI - Associação Comercial e Industrial da cidade. Analisando

\footnotetext{
${ }^{25}$ Precursora da EaD que conhecemos hoje, a Universidade do Ar propagava o conhecimento via rádio - o que ampliou o acesso à informação por parte dos comerciários.
} 
sua biografia, nota-se que a atuação no âmbito da Educação tinha um peso importante. (REGISTRO, 2013).

Ao tornar-se prefeito municipal, foi o responsável pela instalação do primeiro parque infantil municipal, em 8 de dezembro de 1951. Além disso, segundo informações obtidas nos Arquivos do Museu Plinio Travassos dos Santos (também conhecido como "Museu do Café", localizado no interior do campus da Universidade de São Paulo), construiu o prédio na Praça Santo Antônio, (onde foi instalado o Departamento de Cultura) executou o calçamento da Av. Nove de Julho (importante via municipal, que abrigava mansões da elite econômica da cidade) com paralelepípedos e arborizou importantes avenidas municipais.

Durante seu mandato, exercido até 31 de dezembro de 1951, foram publicadas diversas matérias sobre o desenvolvimento do município e a infância escolar. Na tentativa de compreender este período, então, trataremos de algumas - referentes aos jornais Diário de Notícias, A Cidade e Diário da Manhã.

Em 10 de julho de 1949, o Diário da Manhã noticiou a visita de uma Especialista em Puericultura no $2^{\circ}$ Congresso Pan-Americano de Serviço Social, realizado no Rio de Janeiro. Um dos objetivos da organização do Congresso, segundo o Serviço Internacional da Cooperação era "fazer recomendações [...], de maneira a orientar o serviço social" dos países do continente. Sobre esta tentativa de intervenção internacional, é possível estabelecer uma relação com o Relatório Moses (citado no capítulo 2), onde estudos norte-americanos visam influenciar as políticas educacionais e assistenciais do Brasil.

Uma defesa em prol da criação de um Departamento Municipal de Cultura também é empreendida pelo jornal Diário da Manhã em 18 de agosto de 1949, a partir de uma justificativa acerca da grandiosidade da cidade:

Ribeirão Preto é, indiscutivelmente, uma cidade que gosa de justo e merecido conceito como uma das mais cultas do interior do Brasil. Além do grande número de colégios, escolas secundárias e superiores, que comportam cerca de 20 mil alunos, a nossa terra possui inúmeras instituições culturais, científicas e de outras modalidades que nos dão direito a proclamar isto. No setor econômico, RP já estabeleceu as bases do seu patrimônio e agora está em condições de crescer muito, desdobrando-se, multiplicando-se, mesmo, sem necessidade de grandes esforços. [...] Do que precisamos cuidar seriamente é da nossa cultura artística. (DIÁRIO DA MANHÃ, 1949).

A assistência à infância escolar também aparece como uma preocupação no mesmo jornal. A partir da questão da alimentação, é feita uma denúncia sobre a realidade da infância na cidade: “[...] crianças há que mal se aguentam nos bancos escolares. Faces esquálidas, organismo depauperado, implicando na frágil resistência [...]”. E mais uma vez, o poder 
público é invocado como tendo o dever "imperioso e inadiável, de cercar a infância de necessário amparo, especialmente nessa questão da alimentação”. Neste contexto, a instalação dos parques infantis aparece: “já nem citaremos, aqui, a pretendida instalação de parques infantis, agora merecendo destacada atenção da imprensa". O jornal cita, entretanto, "estudos feitos pelos vereadores Dr. Geraldo de Carvalho, Angel Castroviejo e Olimpio Rossi sobre assistência as crianças escolares" e cobra que estes vereadores não descansem "sem que concluído esteja o trabalho" de lutar pelo investimento de Cr\$ 500.00,00 na assistência à infância, segundo o jornal Diário da Manhã de 27 de agosto de 1949.

Em 7 de outubro do mesmo ano, o Projeto de Lei do trio de vereadores é defendido com o argumento de que "a criança precisa de leite, precisa de carne, de verdura, de pão, de assistência médica, de cuidados". (DIÁRIO DA MANHÃ, 1949).

A função social da escola também aparece nos registros de jornal deste ano. O Diário de Notícias apresentou, em 20 de novembro, um artigo que defende o papel socializador da instituição, que deve "ensina-la a ajustar-se ao meio, a conviver brincando ou trabalhando com os companheiros em ambiente de compreensão, de camaradagem, de tolerância, na sua linguagem e nos gestos”. (DIÁRIO DE NOTÍCIAS, 1949).

Em 1 de fevereiro de 1950, um artigo do jornal Diário da Manhã aborda os parques infantis, considerando que a "moda" de instalação havia se encerrado em São Paulo e identificando a falta que a instituição têm feito para a população paulistana. A importância desta notícia diz respeito ao fato de que, pelo exposto, os parques eram instituições cuja fama havia reverberado em Ribeirão Preto por meio das páginas do Diário da Manhã. Essa farpa lançada pelo jornal pode ter colaborado para o processo de implantação realizado por José de Magalhães.

Nestes dias de calor, com a crise de habitação que sofremos, com as classes menos favorecidas vivendo em inquente e cortiços, numa promiscuidade lamentável, os jardins adequados para os fins acima seriam um alívio para a vida dessas pobres famílias. Alívio só, não. Seria uma medida altamente salutar sob todos os pontos de vista, porque contribui para a melhoria eugênica da nossa juventude, revigorando a formação das futuras gerações. [...] com suas gangorras, balanços, piscinas e dezenas de outros meios de diversão para os infantis, se existissem em profusão, haviam de proporcionar aos habitantes dessa imensa metrópole uma alegria invulgar, mudando a fisionomia da vida social. Infelizmente, eles não passam, por enquanto, de meros sonhos, alimentando a imaginação de poetas. (DIÁRIO DA MANHÃ, 1950).

O problema da educação também foi tratado, sob duas óticas: na primeira, destaca-se a criança como "grandeza futura da Pátria", que deve ser bem orientada na formação do seu 
caráter, de acordo com o jornal Diário da Manhã de 03 de março de 1950; na segunda, vem vinculado à uma formação docente que deve cumprir alguns requisitos como: "o amor à Pátria e à Humanidade, à modéstia, a dedicação ao ensino, a tolerância, os bons costumes, o otimismo e a probidade, tanto na vida pública quanto na vida particular" - características que devem ser transmitidas às crianças, segundo o mesmo jornal em 18 de março de 1950.

Um artigo escrito pelo promotor público Peixe Abbade foi publicado no Diário da Manhã de 26 de março de 1950. Nele, Peixe Abbade expressa seu carinho pela cidade, identificando a "fidalguia" e a comunicabilidade de seu povo, tal como a beleza arquitetônica da região central e o dinamismo de suas indústrias.

Em 17 de agosto, uma notícia do jornal A Cidade informou sobre a construção de um Posto de Puericultura no bairro dos Campos Elísios. Além de afirmar que a cidade já possuía dois postos desta natureza (um na Vila Tibério e outro no centro), a matéria tece um elogio valoroso ao prefeito, dizendo que ele "costuma constatar 'in loco' as necessidades do povo".

O Parque Infantil Municipal do Barracão, que mais tarde levaria o nome do supracitado promotor público (veremos adiante) foi notícia em 22 de agosto de 1950. Ao tratar de sua construção na Praça Antônio Prado, o jornal define o prefeito como um grande realizador na cidade: "É esta a primeira vez na história do município que algo realmente importante vai ser feito para o povo do Barracão, que até hoje vive em ruas sem calçamento e desconhecendo uma série de conforto disfrutado por elementos de outros bairros da cidade". (A CIDADE, 1950).

Por outro lado, o prefeito foi alvo de algumas polêmicas publicadas nos jornais locais, entre elas, a existência de professoras contratadas pela prefeitura e que não desenvolviam nenhum trabalho, a interrupção das atividades relativas ás instalações dos parques infantis e a desvalorização econômica de determinados grupos profissionais, noticiados no jornal A Cidade em 15 de setembro de 1950.

Um recenseamento realizado no ano de 1950 e publicado em 3 de janeiro de 1951 no jornal A Cidade, registrou os seguintes dados: em 1940, havia 78.500 habitantes no município e, em 1950 esse número saltou para 94.190 - o que colocou Ribeirão Preto entre as cinco cidades mais populosas do Estado de São Paulo. Além disso, foi concluído que o bairro Campos Elísios é mais populoso do que $60 \%$ das cidades paulistas e, por fim, a previsão realizada pelo recenseamento indicava que, em 1952, a cidade chegaria aos 110.000 habitantes - dado que, de fato, foi atingido. Vale considerar que o órgão realizador deste censo não foi divulgado. 
Julio Pires (2004) afirma que, em 1950, 70,8\% da população de Ribeirão Preto vivia na área urbana, enquanto, no Brasil, a população urbana representava 36,2\% e no Estado de São Paulo, 52,6\%. A importância do setor comercial da cidade também é destacada pelo autor nesse período, tanto no âmbito regional quanto no âmbito estadual, tal como seu papel enquanto centro distribuidor de mercadorias pela área da Alta Mogiana.

Entre 1952 e 1955, Alfredo Condeixa Filho (que havia sido vice de José de Magalhães) exerceu seu primeiro mandato na Prefeitura Municipal. Durante sua gestão, foram inaugurados dois parques infantis: o Parque Municipal do Bosque, em 1952, e o Parque da Vila Tibério (também chamado de Parque Dr. Anita Procópio Junqueira), em 1954.

Um ofício encontrado no Arquivo Municipal datado em 2 de maio de $1952^{26}$, indica que o prefeito Condeixa ainda manteve contato com o DEF-SP e explicita as etapas do processo de elaboração de um projeto de Parque Infantil pelo Departamento. Levando em conta a importância do conteúdo do oficio para o entendimento desse processo, segue um fragmento do mesmo:

Temos o prazer de remeter, em anexo, projeto confeccionado por êste Departamento para o Parque Infantil do Bairro Campos Elisios, assim como, planta do Pavilhão Central no 213 para o referido Parque. Queremos lembrarlhe que a "maquetização" enviada em 19/4 é do Parque Infantil da Vila Tibério, projeto confeccionado por solicitação da Administração anterior e remetido em 31/1. Sendo o terreno dessa Vila bastante acidentado e com área superior ao terreno localizado à Rua João Clopp, não poderá ser aproveitado êsse projeto (desenho 209) na instalação do Parque Infantil do Bairro Campos Elísios, para o qual confeccionamos os projetos que estamos enviando (desenhos $n^{\circ} 213$ e 214). Lembramos, outrossim, que os estudos elaborados por êste Departamento se referem sómente a parte funcional sendo que a estrutura deverá ser estudada por engenheiro desta Prefeitura.

Apesar de o Parque dos Campos Elísios não ter sido concluído por Condeixa (e sim por Costabile Romano, em 1956), o documento deixa claro que já havia um projeto para ele e que já havia, também, uma maquete referente ao Parque da Vila Tibério. Chama atenção o cuidado que o DEF-SP toma em relação a cada terreno onde se propõe a fazer o parque - isso mostra que, apesar de a prefeitura receber o modelo do DEF, as características específicas de cada construção são levadas em conta e a responsabilidade sobre a estrutura final é dividida com os engenheiros do próprio município.

O ano de 1952 destaca-se, nos jornais locais, como o ano em que mais "Campanhas" em prol dos parques infantis foram registradas. No jornal Diário da Manhã, há o registro de

\footnotetext{
${ }^{26}$ O documento pode ser encontrado no Arquivo Público e Histórico de Ribeirão Preto, na Pasta 229 - caixa 43 setor de protocolo - dossiês - parque infantil.
} 
um Festival em benefício do Parque Infantil do Bosque em 29 de novembro, uma doação de uniformes para crianças parqueanas em $1^{\circ}$ de dezembro, distribuição de brinquedos nas instituições em 24 de dezembro e um Sorteio Pró-Parque Infantil em 13 de dezembro. A onda beneficente pode estar relacionada ao fim do ano e às festividades desse período, mas, de qualquer forma, demonstra um envolvimento social considerável em relação as instituições de atendimento à criança pobre.

Em 28 de março de 1953, uma matéria do Diário da Manhã explicita as instituições filantrópicas ribeirão-pretanas que recebem o auxílio financeiro do governo do Estado. São elas: Asilo Padre Euclides, Círculo Operário, Ginásio Nossa Senhora Aparecida, Lar Anália Franco e Sociedade Amiga dos Pobres. O levantamento dessas instituições é essencial, pois elas representam o aparato público de Saúde e Assistência na cidade.

Outro levantamento significativo do jornal Diário da Manhã durante a gestão de Condeixa foi feito em 19 de junho de 1955 e se refere aos estabelecimentos de ensino da cidade (desde a escola rural até a Faculdade de Medicina, instalada naquele ano e considerada como a mais moderna da América Latina), estabelecendo a previsão de investimentos que devem receber até o fim do ano: arrecadação Municipal de Cr\$ 70.000.000,00; arrecadação Estadual de Cr\$ 180.000.000,00; proventos da União equivalentes a Cr\$170.000.000,00 e Autarquias equivalente a Cr\$60.000.000,00.

José Costa assume o posto de prefeito municipal com a saída de Condeixa Filho para a eleição de deputado e a única documentação que associa este prefeito ao processo de implantação dos parques é um ofício de 20 de junho de 1955 que declara a utilidade pública do terreno do Parque Infantil da Vila Tibério.

O ano de 1956 inaugura a gestão de Costabile Romano no Município. Em relação à biografia deste prefeito, chama a atenção o fato de que ele foi proprietário do jornal Diário da Manhã entre os anos de 1933 a 1950 e que, mais tarde, em 1956 criou o jornal O Diário - que não foi analisado na presente pesquisa. Foi um dos fundadores da Associação Paulista de Imprensa, ocupando o cargo de conselheiro e diretor durante 15 anos. Foi Presidente da Liga Ribeirão-pretana de Futebol e Presidente do Botafogo Futebol Clube de Ribeirão Preto de 1949 a 1951.

Esteve à frente da prefeitura municipal até março de 1959, quando deixou o cargo para concorrer nas eleições para deputado. Durante esse período, foi o responsável pela execução de várias obras, entre as quais: construção do novo Mercado Municipal, construção do Primeiro Grupo Escolar, início da construção da Estação Rodoviária do Triângulo, inauguração do reservatório de água do Barracão, construção de novos viveiros de pássaros 
no Bosque Municipal e o prolongamento da Av. 9 de Julho até a Av. Portugal. Em 1956, promoveu uma grande festa em comemoração ao centenário da cidade, onde estiveram presentes várias personalidades, como o Presidente da República Juscelino Kubitschek de Oliveira, o Governador de São Paulo em exercício General José Porphirio da Paz, o Senador Assis Chateaubriand e o Deputado Ulisses Guimarães.

No Arquivo Público Municipal de Ribeirão Preto, entre os Jornais disponíveis para consulta nesse período de gestão de Costabile Romano, duas notícias de 1956 devem ser destacadas: uma, acerca da concepção de criança e outra relativa às arrecadações do município no ano do Centenário. Em 1957, a questão da falta de vagas nos cursos primários e o veto ao Projeto de Lei sobre as creches nos parques infantis são expostas pelo Diário da Manhã, que, em 1958 também publica uma Nota sobre a preocupação da prefeitura com os parques infantis. Por fim, em 1959, a publicação do Depoimento de um vereador municipal pelo jornal A Cidade faz um alerta para a real situação administrativa da cidade. Abaixo, analisar-se-á cada uma dessas publicações.

Em $1^{\circ}$ de janeiro de 1956, o artigo intitulado Alicerce da metrópole do futuro trata da necessidade do cuidado às crianças e do preparo das mesmas para o futuro, já que elas se constituem como "a base em que se alicerça o mundo e a esperança de todos". Sobre as ações em benefício da criança ribeirão-pretana, tem-se: "Em Ribeirão Preto, através de diversos Parques Infantis, a criança é olhada com o desvelo e o carinho necessário, e daí esperamos que nossa "metrópole do futuro" seja e esteja em condições de amanhã superar as condições adversas que dominam hoje".

A arrecadação da cidade é explicitada em uma notícia de $1^{\circ}$ de abril do mesmo ano e expressa uma perspectiva bastante otimista do "desenvolvimento prodigioso" da cidade:

Em 1874, quando da instalação da Câmara Municipal, o orçamento de apenas 1.074 cruzeiros. Em 1920, atingiu a 600.000 cruzeiros. [...] Em 1940 chegou a 3.200.000 cruzeiros. Em 1948, reinicio das atividades do Legislativo, a Camara Municipal encontrou o orçamento de 7.400.000 cruzeiros. Em 1955 arrecadou mais de 65 milhões e neste 1956 atingirá a 100 milhões! (DIÁRIO DA MANHÃ, 1956).

As verbas provenientes do Estado, da União, das Autarquias e do Imposto de Renda também aumentaram consideravelmente desde o início dos anos 1900 na cidade. O reflexo desse desenvolvimento é observado na quantidade de prédios que foram construídos entre os anos de 1922 e 1955, noticiados em $1^{\circ}$ de abril de 1956: “dos 3.400 prédios de 1922, aos 11.400 em 1946, encontra-se a cidade hoje com 22.000 [...] sendo que em novembro [de 1955] a média de construções atingiu uma casa por hora”. 
O aumento da arrecadação e dos prédios municipais, entretanto, não foi acompanhado no âmbito da educação. Em 6 de fevereiro de 1957, o Diário da Manhã mostra que a falta de vagas relativas aos cursos primários da cidade atinge níveis preocupantes: "mais de 1.000 crianças matriculadas estão sem poder receber instrução, por falta de salas e professores".

A reportagem de 20 de março de 1957 mostra outra incongruência do governo municipal: ao expor que o Projeto $n^{\circ} 91$ de implantação de creches nos parques infantis havia sido vetado pela prefeitura, ela define que, apesar de o governo ter argumentado que o projeto ia contra os interesses públicos, a realidade seria que o impedimento estava no fato de que a proposta demandaria a contratação de novos professores, que representariam um gasto de um milhão de cruzeiros e, apesar da estrondosa arrecadação municipal, o prefeito não estaria disposto a realizar tal investimento.

No ano de 1958, uma nota publicada em 10 de outubro no Diário da Manhã expressa que: "Vem a Prefeitura Municipal, desde a gestão Condeixa Filho, cuidando com especial carinho dos Parques Infantis". É preciso considerar que o referido jornal, conforme exposto acima, foi de propriedade do prefeito Costabile Romano, o que coloca em dúvida a parcialidade das notícias. Por outro lado, deve-se destacar que, durante o governo em questão, segundo a documentação obtida no Arquivo Municipal da cidade, há indícios da criação de quatro instituições parqueanas: em 1956, um no distrito de Guatapará (pertencente à Ribeirão Preto no período) e outro no bairro Campos Elíseos; entre 1958 e 1959, outros dois, no bairro Vila Virgínia e no distrito de Bonfim Paulista.

Em junho de 1959, após e renúncia do prefeito de Ribeirão Preto ao cargo (em março, motivado pelas eleições para Deputado) um vereador da cidade concedeu uma entrevista ao jornal A Cidade fazendo uma revelação importante acerca dos gastos municipais: segundo ele, as dívidas contraídas por Costabile Romano atingiram valores astronômicos; além disso, o serviço municipal foi inflado por uma quantidade excessiva de funcionários, entre os quais, muitos familiares do prefeito. $\mathrm{O}$ vereador afirmou que com o orçamento municipal girando em torno de 166 milhões, o gasto com os servidores chegou, na gestão de Costabile, a 168 milhões - o que reflete em dívidas e na ausência de recursos para outras ações (obras públicas, investimentos diversos); em 1956, com o orçamento de 88 milhões, os gastos com o funcionalismo estavam em torno de 40 milhões.

Ainda será preciso verificar a veracidade dessa situação financeira. O que se sabe é que Costabile foi substituído por Áureo Norberto da Silva, que permaneceu no cargo até o retorno de Alfredo Condeixa Filho, eleito pela segunda vez e cuja posse ocorreu em 1960. 
Entre 1960 e 1964, quatro parques são inaugurados na gestão de Condeixa no comando da prefeitura: em 1960, é inaugurado na Vila Paulista; em 1963, na Vila Recreio (atual Parque dos Bandeirantes); em 1964, na Vila Abranches; e, em 1965, no bairro Santa Cruz do Jacques (atual Jardim Irajá), que recebeu o nome de Parque Infantil Ana Gabarra.

Algumas mudanças ocorreram na cidade durante o início da década de 1960. Pires (2004) define que nesse período, $81,1 \%$ da população ribeirão-pretana já vivia na área urbana, enquanto no Brasil esse índice era de $45,1 \%$ e no Estado, 62,8\%. Além disso, afirma que a década de 1960 marca a "consolidação do município como centro comercial, financeiro e de serviços, com destaque particular para a concentração das atividades culturais, educativas e de saúde”. (PIRES, 2004, p. 181).

Em 1962, segundo matéria publicada no dia $1^{\circ}$ de junho de 1963 no Diário da Manhã, a população da cidade chegou a 141.000 habitantes e a arrecadação (municipal, estadual, federal e de autarquias) chegou a mais de 3 milhões de cruzeiros.

Em termos de investimentos em Educação, é preciso destacar a satisfação da imprensa em relação às ações do governo, como por exemplo a notícia do jornal Diário da Manhã de 30 de setembro de 1962:

Tem sido uma constante da administração Condeixa Filho a atenção para com os Parques Infantis. Nesse setor, está Ribeirão Preto em ótima situação. [...] todos os parques contam com assistência ampla de professoras, dentistas e com piscina, a par de curso pré-primário. Contando ainda com a cooperação particular, tem sido possível pleno atendimento à milhares de crianças, especialmente na parte da alimentação.

A Secretaria da Saúde, na pessoa do professor Zeferino Vaz, também demonstrou, em 2 de abril de 1963, otimismo em relação á propostas dos parques municipais "não só pela organização, como pelo serviço que prestam à coletividade, tendo prometido ao prefeito Condeixa Filho toda a assistência que lhe fora solicitada”. (DIÁRIO DA MANHÃ, 1963).

A inauguração do Parque da Vila Recreio (Bandeirantes) ocorre em 12 de maio de 1963. A notícia publicada sobre o evento no jornal Diário da Manhã, define que, localizado à Rua General Câmara, o mesmo possuía capacidade para atender a 500 crianças.

Ainda na gestão de Condeixa, merece destaque a mudança do nome do Bairro do Barracão para "Ipiranga" (em 10 de abril de 1962) - nome que permanece até os dias de hoje, a convocação de professoras substitutas para o trabalho em parques infantis (em maio de 1962), a publicação em 2 de junho de 1963 do recenseamento do Ensino na cidade - 34 mil matriculados nos diversos cursos oferecidos pela cidade (desde o setor primário, com 18.600 alunos até os cursos de arte, de contabilidade, industriais, eclesiásticos e de formação 
superior) e, em 1964, as campanhas em prol dos parques infantis organizadas pelos gráficos, pelos usineiros e por casas de show da cidade. Todas as notícias constam no jornal Diário da Manhã.

Sobre as relações com o DEF-SP, cumpre considerar que, já em 1964, o Departamento Municipal de Educação, Ensino e Cultura ofereceu, em parceria com o Serviço de Recreação e com a Delegacia Regional do DEF-SP, um curso destinado às professoras infantis da cidade.

Welson Gasparini foi o sucessor de Condeixa no cargo de Prefeito Municipal e permaneceu no comando da cidade até 1969. Uma de suas bandeiras era o oferecimento de escolas para todas as crianças em idade escolar, segundo o jornal Diário da Manhã de 26 de agosto de 1966. O que ocorreu, entretanto, de fato, foi o engavetamento de propostas de abertura de novos Grupos Escolares Municipais e a mudança do caráter de atendimento dos parques infantis já existentes - que tornaram-se Escolas Parqueanas Municipais voltadas para a aprendizagem de ofícios, de acordo com o jornal Diário da Manhã de 8 de março de 1966, sobre a qual trataremos mais adiante.

No que se refere à legislação sobre parques infantis, quatro documentos assinados por Welson Gasparini (que cumpria seu segundo mandato na prefeitura) devem ser destacados. Em primeiro lugar, a Lei 2763 de 1973 (RIBEIRÃO PRETO, 1973b), que dispõe sobre a organização da administração municipal (criando a Secretaria da Fazenda, a Secretaria de Governo e a Secretaria de Obras e Serviços) e define em seu Artigo 12 que "a implantação das Secretarias será progressiva e à medida que as possibilidades financeiras e administrativas do Município o permitirem”; em segundo lugar, a Lei 2897 de 1974 (RIBEIRÃO PRETO, 1974a), que cria a Secretaria Municipal da Educação, Saúde e Bem Estar Social; em terceiro lugar, o Ato no 132 de 31 de julho de 1977 (RIBEIRÃO PRETO, 1977b) que estabelece, em seu Artigo $7^{\circ}$, as seguintes divisões na Secretaria da Educação, Saúde e Bem Estar Social: o Departamento de Educação ficará desmembrado em duas partes - a Divisão de Unidades de Ensino de $1^{\circ}$ Grau e a Divisão de Ensino de Unidades Isoladas (Curso Popular de Artes Plásticas, Curso Municipal de Madureza, Escolas Municipais Isoladas, Setor de Alimentação Escolar e Parques Infantis); o Departamento da Cultura será composto por: Coordenadoria de Promoções Culturais, Coordenadoria do Patrimônio Histórico, Coordenadoria dos Teatros Municipais, Coordenadoria dos Museus Municipais e Setor de Expediente e Documentação; o Departamento do Bem Estar Social ficará responsável pela Coordenadoria dos Serviços de Assistência aos Servidores Municipais e pela Coordenadoria de Programas Comunitários; e, por fim, o Departamento da Saúde e Higiene será representado por duas frentes: a Divisão de Saúde (Setor de Serviços Internos e Administrativos, Setor do Pronto Socorro Municipal, 
Setor do Pronto Socorro Infantil, Setor Odontológico, Setor de Enfermagem e Setor de Transporte) e a Divisão de Higiene (Seção dos Cemitérios Municipais, Seção do Matadouro, Setor do Mercado Municipal e Seção de Fiscalização de Higiene e Saúde).

Essa estrutura reforça a noção de que os parques adquiriram, ao longo do tempo, caráter educativo e assistencial que possuíam no início da década de 1950.

A partir da gestão de Gasparini, portanto, as instituições foram perdendo o caráter assistencialista e a preocupação com a educação sanitária das crianças. Transformaram-se em estabelecimentos de formação pré-primária e, gradativamente, foram dando lugar às escolas de $1^{\circ} \mathrm{Grau}$.

\section{2 - Implantação dos parques infantis em Ribeirão Preto}

Para compreender a mobilização que deu origem aos parques infantis em Ribeirão Preto, alguns dados obtidos na pesquisa de Iniciação Científica citada anteriormente (FERREIRA, 2010) serão úteis na exemplificação da relação estabelecida entre Prefeitura Municipal de Ribeirão Preto e Departamento de Educação Física do Estado de São Paulo. Parte dos materiais considerados aqui está localizada em uma Pasta denominada "Parques Infantis", de $n^{\circ} 229$, no Arquivo Público e Municipal de Ribeirão Preto e estão disponíveis para consulta. Além disso, outros documentos que contam a história do início do atendimento à infância nos ajudarão a contextualizar a realidade do município neste período.

Em 13 de junho de 1934, um artigo do jornal Folha da Noite, trata do valor higiênico e educativo dos parques instalados em São Paulo e procura mobilizar seus leitores para o entendimento de que "abrir parques equivale a fechar sanatórios":

Os parques desempenharam um papel de capital importância na educação
physica da criança. A infância necessita de movimento. Ella é todo
movimento. Não há criança que não brinque. Ao menos, pode-se garantir
que as que não apreciam os brinquedos são anormaes e as que deles são
privadas correm sériamente o risco de também perder sua saúde. O
brinquedo, o exercício traz saúde e vigor. Mas, para que a movimentação
physica se realize com os benefícios para o menino, é preciso que ela se
processe num ambiente conveniente, livre das imundices dos quintaes de
cortiço e do ar viciado dos aposentos É preciso orientar as atividades infantis
e proporcionar-lhes um ambiente favorável. (FOLHA DA NOITE, 1934).

Esta matéria é de fundamental importância para o presente estudo, pois é uma amostra de um modo de representar os pobres, bastante ocorrente entre as elites e com fortes ecos na imprensa, além de ser a favor dos remédios usuais para a pobreza: higiene e disciplina. Neste 
contexto, a necessidade da instalação de um aparelho de lazer é vista como uma questão de saúde.

Prandi (2015, p. 116) chama atenção para o caráter da abordagem dos jornais locais quando o assunto era a instalação de parques infantis:

[...] o discurso jornalístico reiterava o caráter de assistência, socorro, amparo e doação do poder público aos pobres, especialmente aos seus filhos e filhas, a fim de demonstrar às outras classes sociais (plenas de cidadãos e eleitores) a política posta em prática para amparar e educar os desassistidos.

Entre os ofícios localizados, o primeiro documento que registra o contato entre estes órgãos data de 29 de junho de 1947 e demonstra a primeira ação do Departamento na cidade: nele, o diretor geral do DEF-SE questiona o Prefeito sobre o seu interesse na construção de um parque infantil na cidade de Ribeirão Preto. Três meses depois, um novo ofício do Departamento informa ao prefeito Rubem Moreyra que uma técnica de educação viria à cidade para conhecer a realidade local e colaborar com o governo municipal na construção do primeiro parque infantil. Essa técnica, conforme o Decreto $n^{\circ} 9605$ de 12 de outubro de 1938 (SÃO PAULO, 1938), faz parte do quadro pessoal do DEF-SP que conta, ainda, com diretores (geral, técnico e administrativo), assistente técnico, secretário geral, 14 escriturários, inspetores (gerais, regionais e chefe), auxiliares técnicos, desenhistas (projetista e auxiliar), fotógrafo, bibliotecário, assistentes médicos, dentista, professores (esgrima, dança, música), bedéis, porteiro e motorista.

Após a visita, em 30 de setembro de 1947, o Diretor do DEF-SP escreve ao prefeito agradecendo a acolhida dedicada a sua técnica e explica que a planta do primeiro parque da cidade estava em fase de elaboração por parte de sua equipe. Dalben (2009, p. 61) afirma que o órgão estadual mantinha, entre outros, uma repartição de desenhos e projetos, "na qual se realizavam plantas arquitetônicas de Parques Infantis". Além disso, demonstra que "a arquitetura das novas construções deveria obedecer aos preceitos higiênicos ditados pelos médicos e engenheiros. A circulação do ar, assim como a iluminação natural eram regras a serem seguidas na elaboração das plantas arquitetônicas dos novos prédios”. (DALBEN, 2009, p. 27).

Em poucos dias ${ }^{27}$, o DEF-SP encaminha ao prefeito um novo documento sobre os parques infantis ${ }^{28}$ : este associa o caráter moderno de uma sociedade às ações que o governo

\footnotetext{
${ }^{27}$ Não há registro acerca da data exata deste documento. O que se supõe devido a uma anotação feita na primeira página, é que o mesmo foi arquivado pela Prefeitura em 21 de outubro de 1947.

${ }_{28}$ O documento pode ser encontrado no Arquivo Público e Histórico de Ribeirão Preto, na Pasta 229 - caixa 43 setor de protocolo - dossiês - parque infantil.
} 
articula em favor da educação e da assistência infantis. Indica, ainda, que entre as diversas instituições que têm a função de educar as novas gerações, os parques infantis são de "imperiosa" necessidade, à medida que oferecem uma educação completa, pautada na recreação, na brincadeira, no jogo e na interação entre crianças - dando origem, assim, ao hábito da disciplina e à capacidade de trabalho. Em termos de localização, esclarece que a instalação deve ser feita em bairros populares de alta população infantil.

O terreno mais adequado para o Parque será, se possível, plano e deverá possuir área nunca inferior a $8000 \mathrm{ou} 10000 \mathrm{~m}^{2}$. Deve-se providenciar a arborização, de acordo com o plano, que deverá ser traçado, evitando-se ainda arbustos e tufos de plantas. [...] Todo o parque deve ser cercado, afim de se tornar difícil a intromissão de estranhos e facilitar a vigilância das crianças. A cerca viva é a mais aconselhável, porque se torna mais alegre o ambiente. (DEPARTAMENTO DE EDUCAÇÃO FÍSICA DE SÃO PAULO, 1950, p. 2).

Sobre o edifício, o DEF-SP discrimina os espaços que devem ser construídos: galpão coberto, sala de professores, sala de exames, biblioteca, copa e cozinha, banheiros (um para cada vinte crianças matriculadas), chuveiros (um para cada 10 crianças - sendo individuais para as meninas e coletivos para os meninos), vestiários e depósito para os materiais móveis. Além disso, devem apresentar duas quadras destinadas aos jogos: um na forma de campo de ginástica, com 40x50m e instalação de equipamentos de lazer e outro, de terra batida, para práticas de voleibol e bola ao cesto. O parque contará, também, com uma piscina de profundidade $1 \mathrm{~m}$ a $1 \mathrm{~m} 20$, com um "tanque de vadear" para que as crianças maiores possam brincar na água e com um tanque de areia instalado à sombra das árvores. O jardim, a horta e os viveiros são identificados como essenciais ao parque e sua manutenção fica à cargo das crianças e de suas professoras. Em relação aos profissionais, o documento especifica que, tendo uma frequência de 200 crianças e funcionando 10 horas por dia, o mínimo de pessoal indicado é: uma diretora, duas professoras de Educação Física, duas professoras de Educação Infantil, duas professoras de recreação, uma educadora sanitária, um zelador, quatro vigilantes, um médico e um dentista. Sobre o DEF-SP, consta:

O Departamento de Educação Física, fornecerá aos Municípios interessados na construção de um Parque Infantil, todas as informações e instruções, para a escolha do terreno, projeto do Parque, plantas do pavilhão, desenhos de aparelhos e moveis e instruções sobre escolha do material de Educação Física, jogos, etc. (DEPARTAMENTO DE EDUCAÇÃO FÍSICA DE SÃO PAULO, 1950, p. 8).

Em 24 de outubro de 1947, duas plantas enviadas pelo DEF-SP chegam à prefeitura de Ribeirão Preto, para avaliação do então prefeito Rubem Aloysio Moreira. 
A documentação histórica do Arquivo indica, entretanto, que devido à troca de prefeitos realizada entre 1947 e 1948, a comunicação com o DEF-SP ficou prejudicada e, consequentemente, os projetos precisaram ser refeitos pelo órgão estadual. Na relação de ofícios encontrados para o presente estudo, temos um indício de que foi apenas em 1950 que novas orientações de parques infantis municipais chegaram à prefeitura. Organizados em três documentos, estavam explícitas as despesas mensais (salários da diretora, professora, serviçais e porteiro) e anuais (soma dos salários de funcionários, lanches e diversos), os materiais necessários para o funcionamento do parque e, por último, as funções delegadas às diretoras e professoras na instituição.

Nos documentos do DEF-SP, chama atenção o fato de que aquelas funções relacionadas ao trabalho direto com as crianças no parque são sempre definidas no gênero feminino - (professoras, diretoras) ao passo que os cargos ligados às crianças de forma mais superficial são tratados a partir do gênero masculino (fotógrafo, médico, inspetor). Guacira Louro (1997), em conhecido texto sobre as mulheres e o magistério, faz um paralelo entre o papel exercido pelo gênero feminino e pelo masculino no âmbito da educação.

Sobre as funções do cargo de diretora, tem-se a responsabilidade pela assistência técnica e educacional, tal como o desenvolvimento e orientação de atividades que tornem o parque atraente e estimulante, a elaboração de planos de aprimoramento da instituição (destinados à prefeitura) e o controle mensal e anual de documentos para o Departamento de Educação Física. À professora, caberia a função de preparar e executar atividades recreativas, os serviços de colaboração com a diretora, o registro das atividades realizadas e as aulas de educação física.

Em 14 de agosto de 1950, Plínio Travassos dos Santos ${ }^{29}$, diretor do Departamento de Cultura de Ribeirão Preto, assinou as "Instruções aos Parques Infantis" em um ofício timbrado pelo DEF-SP. O conteúdo desse material é detalhado no que diz respeito às rotinas, espaços e atividades desejáveis em uma instituição parqueana. Sistematizadas em tópicos, as orientações são iniciadas pela questão do horário - que deve seguir as normas do DEF-SP e, caso haja necessidade de modificação, esta deve ser aprovada pela chefia do Serviço de Parques Infantis: sendo assim, no período da manhã, segundo o documento, a primeira atividade diz respeito à higiene das crianças atendidas na instituição (trata-se de uma "revisão" acerca do asseio, das doenças de pele e, caso necessário, orientações e tratamentos);

\footnotetext{
${ }^{29}$ Professor de história ligado aos estudos da Museologia teve importância fundamental na construção da História de Ribeirão Preto, tanto pelos seus estudos quanto pela iniciativa de preservar o patrimônio material da cidade no Museu Histórico que hoje recebe o seu nome. (RIBEIRÃO PRETO, 2000).
} 
em seguida, devem ser realizadas as atividades que exigem maior movimentação; o lanche dá sequência à rotina e, para as crianças da $1^{\mathrm{a}}$ turma (divisão etária), fica previsto um repouso de 15 a 20 minutos. As atividades de jardinagem são extensivas para as $1^{\mathrm{a}}, 2^{\mathrm{a}}$ e $3^{\mathrm{a}}$ turmas e têm o objetivo de despertar o interesse e o cuidado pela natureza; há também as práticas de canto e declamação, onde são ensinados os hinos cívicos, as canções tradicionais e os pequenos versos; o momento de dramatização é organizado de forma a desenvolver as habilidades com a linguagem oral das crianças. São consideradas, ainda, as seguintes atividades: desenho e moldagem a partir do uso de materiais diversos, jogos de construção, concursos de palavrascruzadas e charadas, produção de jornais sobre o cotidiano da instituição, recortes de revistas, jogos variados (xadrez, dama, dominó, quebra-cabeça), roda cantada, aulas de Educação Física, mímicas e utilização dos equipamentos de lazer instalados no parque. Além disso, em termo de espaços diferenciados, o documento cita a biblioteca, a casa de boneca (com diversos objetos próprios desse ambiente) e o tanque de areia.

Em um documento de 4 de abril de 1951 endereçado ao prefeito José Magalhães, o DEF-SP relaciona, a pedido do próprio prefeito, os materiais necessários ao parque que estava em construção. Comunica, também, que o projeto para construção da segunda instituição da cidade está em execução.

Outro documento, registrado em 11 de agosto de 1951, o DEF-SP envia para Ribeirão Preto um ofício no qual disponibiliza ao prefeito da cidade duas profissionais do Departamento qualificadas para os cargos de diretora e professora do primeiro parque da cidade. Explicitando as funções de cada cargo, fica claro que a intenção é subordinar todas as atividades e rotinas do parque ao DEF-SP. À Diretora caberia, segundo o documento, as funções: de prestar assistência técnica e educacional em todos os momentos de atividade no parque, levar ao prefeito questões relacionadas à melhoria e ao desenvolvimento da instituição, "remeter mensalmente ao DEF-SP" os diários de atividades mensais, a lista de providências a serem tomadas pelo Departamento, a lista de sugestões ao mesmo e os relatórios das professoras; além disso, anualmente era necessário entregar alguns controles dos parques como o horário das atividades ali desenvolvidas e a escala de férias dos funcionários; por fim, a diretora deveria "comparecer às reuniões pré-determinadas pela Chefia de Serviços de Parques Infantis, apresentando sugestões sobre os serviços e outros trabalhos de interesse". Às professoras, competia a realização das atividades de educação física e recreação com as crianças, a colaboração com a diretora da unidade, o registro do trabalho (que deveria ser analisado mensalmente pelo DEF) e o comparecimento nas reuniões pré-determinadas pelo Serviço de Parques Infantis. 
O primeiro parque infantil municipal é inaugurado em 8 de dezembro de 1951. Segundo o Jornal A cidade, a instalação desta obra social era uma grande preocupação do Prefeito José de Magalhães que, além de atender às crianças pobres do bairro, estava, também, articulando obras voltadas para a melhoria nas redes de água e esgoto do Barracão. Na mesma data, o Jornal Diário de Notícias publicou uma reportagem exaltando a modernidade, a proposta eugenista do parque e o caráter popular da instituição, além de citar o serviço de transporte que a prefeitura se comprometia a oferecer, ligando a área central ao bairro do Barracão - para facilitar o acesso da população ao local. Já em 15 de dezembro do mesmo ano, uma nota publicada no Jornal Diário da Manhã anuncia a primeira doação recebida pelo parque: dois mil cruzeiros advindos da Associação Comercial e Industrial de Ribeirão Preto para a instalação da fonte luminosa que seria ligada no Natal da instituição.

No mês subsequente, entretanto, um ofício enviado pelo Departamento de Cultura do Estado de São Paulo ao prefeito recém-empossado Alfredo Condeixa Filho revela que o cenário ribeirão-pretano não era satisfatório do ponto de vista dos investimentos em Cultura e Educação. Consta no ofício ${ }^{30}$ o seguinte reclame:

Pela minha representação [...], esclareci os motivos da precária situação do ensino municipal, decorrente da falta de uma lei que organize e discipline e de falhas provindas de determinações dezerrazoadas das administrações anteriores. Infelizmente essa situação perdurou durante todo o último período administrativo, apesar do desejo que sempre manifestei [...] e de projeto e substitutivos que elaborei, organizadores deste Departamento, os quais, encaminhados à DD. Câmara Municipal, até hoje não tiveram andamento.

O documento informa, ainda, que a divisão que a prefeitura estabeleceu no Departamento Municipal de Cultura (Serviço de Ensino, Serviço de Parques Infantis e Recreação, Serviço de Difusão Cultural e Museu e Serviço de Turismo) não corresponde à indicação do Departamento Estadual de Cultura, que previa apenas duas Seções - de Educação (compreendendo ensinos pré-primário e primário, os parques infantis e os parques de recreação) e de Cultura (correspondente aos museus, bibliotecas, cinema educativo, bosque, zoológico e turismo). Há no documento, por fỉm, uma orientação que determina uma articulação gradativa entre o Departamento de Cultura Municipal e o Serviço de Assistência Médico Escolar da cidade - aspecto que não estava sendo cumprido pelo governo local.

A partir desse documento, deve-se considerar que a cidade já possuía um Serviço de Parques Infantis em 1951 e que, mesmo assim, fez uso do modelo enviado pelo DEF-SP em

\footnotetext{
${ }^{30}$ O documento pode ser encontrado no Arquivo Público e Histórico de Ribeirão Preto, na Pasta 229 - caixa 43 setor de protocolo - dossiês - parque infantil.
} 
1950. Cumpre definir, portanto, quais órgãos eram responsáveis por quais definições no processo de implantação das instituições de atendimento à criança pobre.

Essa questão é abordada pelo Diretor Geral do DEF-SP em uma carta de 2 de maio de 1952 destinada ao prefeito Condeixa, onde o diretor esclarece que o projeto de parque para os Campos Elísios que estava sendo enviado por ele continha apenas a "parte funcional"; a "parte estrutural" deveria ser feita pelo engenheiro da cidade.

Ainda em relação aos limites da função do DEF-SP e das ações municipais, um ofício de 24 de Abril de 1952 é revelador em relação às verbas do parque infantil. Ao informar o prefeito de Ribeirão Preto que o Departamento Estadual está organizando um encontro entre as crianças parqueanas no município de Santos, o Diretor do DEF-SP Dr. Arthur Alcaides Valls solicita o envio de verbas da prefeitura para a viagem, considerando uma estadia de 10 dias para 20 crianças e 2 professoras. $\mathrm{O}$ aval do prefeito é registrado poucos dias depois.

Sendo assim, temos, até 1952, alguns indícios de como o governo municipal e o Departamento Estadual de Cultura se articulavam em relação aos parques: enquanto este se ocupava de orientações, projetos e plantas, aquele era responsável pelas definições finais dos prédios e pela destinação de verbas. É preciso levar em conta, entretanto, que esta vinculação não era encarada como regra pelo prefeito Condeixa Filho que, no mesmo ano de 1952, enquanto estabelecia contato com o DEF-SP acerca dos parques, também fez solicitações de plantas a um escritório de engenharia particular da cidade, denominado "Ferreira de Souza Ltda" - prova disso é um anteprojeto de parque infantil que foi enviado ao prefeito em 19 de fevereiro de 1952, caracterizado pelos idealizadores como funcional e econômico. A descrição do anteprojeto revela os seguintes ambientes: pátio coberto, de $77 \mathrm{~m}^{2}$, palco com vestiários femininos e masculinos, sala de professores e da administração, de $18 \mathrm{~m}^{2}$ e banheiros para meninos, meninas, senhoras e homens; sobre a capacidade, fala em 70 crianças mas destaca que, em ocasiões festivas, acomoda até 130. Ao tratar da estrutura física, esclarece que, apesar de ser uma obra barata, deve ser esteticamente atraente para as crianças; a construção seria de alvenaria e concreto armado, com telha "brasilit", "eternit" ou alumínio. Em 8 de março do mesmo ano, o prefeito escreve ao escritório parabenizando pelo anteprojeto e alegando que o mesmo satisfaz o ideal da prefeitura. Não há, porém, confirmação de que este projeto foi o escolhido pelo governo municipal.

Um artigo publicado no Álbum Comemorativo do $1^{\circ}$ Centenário da cidade, em 1956 cita Platão para reafirmar a importância do atendimento à criança pré-escolar, já que o filósofo defendia que "dos primeiros anos devida da criança depende sua vida toda". Além 
disso, trata do significado social dos parques municipais (em 1956, Ribeirão Preto já tinha quatro):

Não pensem os menos avisados que os parques infantis sejam fornalhas onde ardem os ensinamentos de cultura geral, para enriquecer o intelecto das crianças, cravando-lhe a semente basilar para os grandes conhecimentos futuros. Isto não, porque este papel compete aos Grupos Escolares! Aos Parques Infantis cabe preparar o desenvolvimento físico e mental das crianças através de recreações apropriadas, cuidando também, do lado cívico, através de comemorações das principais datas da nossa História. Por outro lado, o convívio das crianças desde a mais tenra idade, com outros meninos, proporciona-lhe grande desembaraço social, tornando mais firme a sua atenção, elucidando sua capacidade viso-motora, imprimindo maior confiança no seu auto-domínio, propiciando-lhe esclarecida iniciativa própria e, por tudo, fecundando sua inteligência embrionária. Fóra estas vantagens, existe a alimentação, a da assistência odonto-médica sob orientação bem concatenada de Diretores e Professoras especializadas no assunto. (SOUZA, 1956, p. 83).

\section{3 - Os parques infantis se incorporam à paisagem ribeirão-pretana}

Este último item do capítulo 3 se propõe a definir as formas como as instituições parqueanas assumiram o seu lugar no município, ou, dito de outra forma, como foram assimilados pela administração local e pela sociedade para a qual prestou os seus serviços. Além disso, demonstra que, apesar de se constituir como um projeto do DEF-SP, os parques aqui instalados receberam características próprias e distintas das demais cidades onde foi implantado. Para tal, vamos analisar o perfil geral do município e, em seguida, vamos nos aprofundar nos aspectos relacionados aos três primeiros parques que foram construídos no mesmo.

Em relação à Divisão Administrativa, o Decreto-lei Estadual n ${ }^{\circ} 14334$ de 30 de novembro de 1944 (SÃO PAULO, 1944) estabelece que o Município estava composto pelo Distrito de Ribeirão Preto, pelo Distrito de Guaturamo e pelo Distrito de Guatapará; mais tarde, em 30 de dezembro de 1953, a denominação "Guaturamo" é substituída por "Bonfim Paulista" (Lei estadual $n^{\circ}$ 2.456) - alteração que se mantém até os dias de hoje (SÃO PAULO, 1953). Em 28 de fevereiro de 1964, por meio da Lei estadual 8.092 (SÃO PAULO, 1964), há um desmembramento entre Ribeirão Preto e Dumont; o mesmo ocorre em relação à Guatapará por meio da Lei estadual no 6645 apenas em de $1^{\circ}$ de Janeiro de 1990 (SÃO PAULO, 1990). Isso significa que durante o período da pesquisa em questão, Guatapará não deixou de ser Distrito de Ribeirão Preto. 
Para iniciar a discussão acerca dos parques infantis municipais, é necessário considerar que, desde 1983, a partir do Decreto n 333 de 26 de dezembro, a cidade passou a ser dividida em subsetores:

\begin{abstract}
ARTIGO $1^{\circ}$ - Com fundamento no Decreto-Lei Complementar $n^{\circ} 9$, de 31 de dezembro de 1.969 (Lei Orgânica dos Municípios) no seu artigo $3^{\circ}$, Incisos VIII e IX e para as finalidades em geral, a obtenção de dados indispensáveis a planejamento de atividades relacionadas a saúde, educação, saneamento, abastecimento, comunicação, segurança, transporte e outros, bem como, para possibilitar com maior precisão, levantamentos de densidade demográfica, definição de zonas residenciais, comerciais e industriais, expansão urbana, distribuição dos serviços públicos etc, ficam por este decreto oficializadas as delimitações dos Setores e Subsetores do Distrito Sede de Ribeirão Preto. [...] ARTIGO $3^{\circ}$ - Entende-se por setor a divisão do Distrito Sede em cinco áreas distintas delimitadas por acidentes geográficos, barreiras físicas e vias de tráfego pesado, localizados de acordo com os quadrantes Norte, Leste, Sul, Oeste e Central.

ARTIGO $4^{\circ}$ - Entende-se por subsetores a subdivisão dos setores em áreas pré dimensionadas, e com características próprias. (RIBEIRÃO PRETO, 1983).
\end{abstract}

Apesar de não existirem no período histórico referente a esta pesquisa, os subsetores serão úteis na visualização da localização dos parques (figura 4). Para tratar de cada parte, destacar-se-á o subsetor correspondente, tal como os bairros que o mesmo abrange.

Os subsetores que receberam os primeiros parques municipais são: O-6, L-2 e O-2. Nota-se que eles estão localizados de forma relativamente próxima - em áreas quase centrais, o que nos parece ser justificável pela demografia das regiões (bairros populosos, como indicam os jornais locais). 


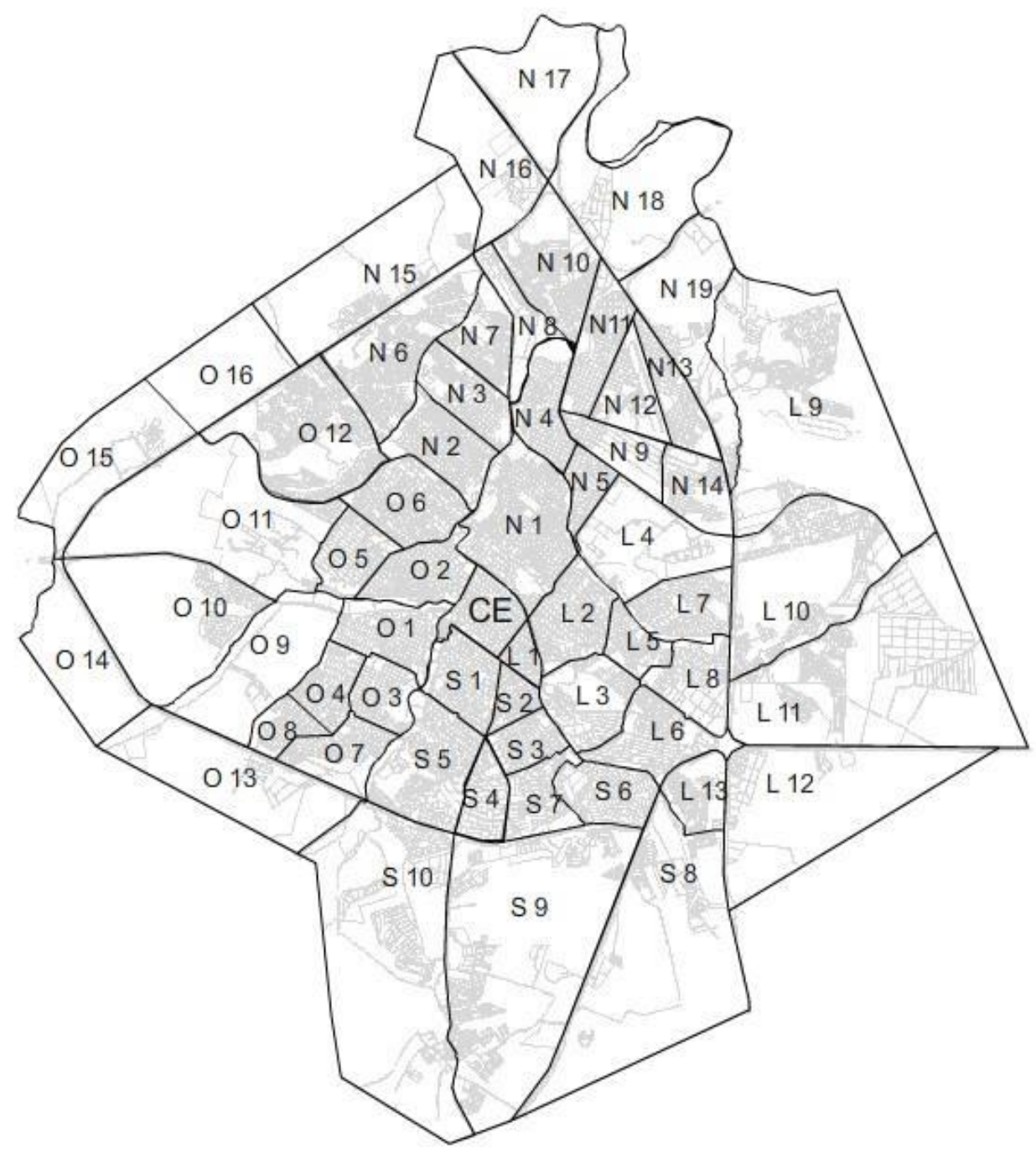

Fonte: LASTÓRIA (2008)

Rubem Cione (1997) explica que o bairro do Barracão começou com um grande espaço construído pelo governo para receber os imigrantes que chegavam à cidade após a abolição da escravatura, para trabalharem na lavoura. Tornou-se, ao longo do tempo, um bairro operário e, assim, foi adquirindo estrutura. Uma reportagem do Diário da Manhã em $1^{\circ}$ de junho de 1966 se refere ao bairro do Barracão como o "Gigante" e elenca os melhoramentos registrados no início dos anos 1960: “[...] Ali estão 2.200 prédios e novas construções surgem por todos os lados. É um bairro operário e já possui suas indústrias". Além disso, ressalta a importância do Grupo Escolar, do parque infantil e das Praças instaladas no bairro.

Sobre o bairro referente ao Parque Infantil do Bosque, o jornal Diário de Notícias apresenta, ainda em 27 de outubro de 1949, que "um dos mais belos recantos da cidade, é um atestado da capacidade realizadora do ribeirão-pretano. Situado em lugar privilegiado, aquele bairro tem progredido de uma maneira notável”. Cione (1997) revela, entretanto, que apesar 
de possuir uma boa infraestrutura e ser habitado por uma classe média-alta, no passado o bairro foi considerado como um lugar de abandono. A construção do parque infantil e a mobilização dos moradores locais representaram o início das melhorias junto às autoridades municipais.

Em relação à Vila Tibério, Cione (1997) identifica esse como o "paraíso dos malandros" e vincula sua história à antiga estação ferroviária da Mogiana:

\begin{abstract}
A história de Vila Tibério pode ser dividida em dois períodos diferentes, marcados pelas porteiras da Mogiana, isto é, com elas e depois delas. Em meados da década de 60, a rua Luiz da Cunha, prolongamento da rua Duque de Caxias, era a única ligação da Vila com o centro da cidade, pois as porteiras e trilhos da estrada de ferro Mogiana impediam o prolongamento das ruas General Osório e São Sebastião. [...] A retirada dos trilhos ferroviários e das porteiras, permitindo o prolongamento das ruas e a interligação do bairro com a cidade foi fundamental para o progresso de Vila Tibério. O responsável pela atitude foi o prefeito Welson Gasparini [...]. (CIONE, 1997, p. 556).
\end{abstract}

Os problemas do bairro foram explicitados em 7 de julho de 1962 pelo jornal Diário da Manhã, que identificou o abastecimento de água no local como sendo insuficiente, a “algazarra das crianças” como exagerada e, por fim, denunciou a má qualidade do asfalto.

$\mathrm{O}$ aprofundamento nestes três bairros se justifica pelo fato de que a atuação do DEFSP pareceu estar mais presente nas decisões que envolveram estes três primeiros parques infantis municipais. As instituições que vieram em seguida seguiram as propostas advindas deles e têm, inclusive, Leis de criação muito semelhantes entre si. Mais informações sobre os demais parques municipais estarão entre os anexos do presente trabalho.

Deve-se levar em conta que, conforme afirma Gabriela Campos Darahem (2011), durante o período de existência dos parques municipais, as áreas que circundavam essas instituições eram repletas de terrenos vazios e que, atualmente, o cenário é bem diferente, pois todos os antigos endereços apresentam elementos de integração com a cidade, mesmo que não tenham se transformado em Escolas Municipais de Educação Infantil.

Sobre as formas de ingresso de crianças nos parques infantis municipais, não localizamos nas fontes consultadas informações mais precisas. O Álbum Comemorativo do $1^{\circ}$ Centenário, por exemplo, divulga dados relativos a quantidade de alunos matriculados em contrate com a quantidade de crianças que frequentavam a instituição diariamente: neste comparativo, o parque do Barracão, por exemplo, registrava 2.156 matrículas e frequência de apenas 400. De posse desta informação, a hipótese que temos é de que havia uma "lista de espera" para as famílias que realizavam a matrícula de seus filhos. Maria Santos (2005) se 
refere ao processo que se desenrolava com as famílias cujos filhos buscavam vagas nos parques paulistas em meados de 1950. Apesar de supor que o processo nos parques de Ribeirão Preto era mais simplificado, é importante ter noção dos procedimentos adotados na capital, a partir de uma depoente:

A criança que se matriculava em Parque Infantil passava primeiro pela
educadora sanitária. Nós fazíamos uma anamnese para depois passar para o
médico. Perguntávamos como havia sido o parto da mãe, as primeiras
doenças, as vacinas, onde morava. Naquele tempo não tinha tanta favela
como hoje, tinha cortiço. A gente precisava saber muitos detalhes sobre a
saúde. Fazíamos também uma constelação familiar, onde a criança era
situada, se tinha pai ou não, quais eram as pessoas que a rodeavam. Depois,
passávamos para o médico que fazia exame físico, clínico. A partir disso ela
começava a frequentar. A gente via o uniforme, fazia as recomendaçães
iniciais, de higiene que não era tão bem cuidada. Essa era a primeira parte.
Depois, a gente dava aula para as crianças sobre higiene pessoal, higiene do
lar, higiene da escola, os cuidados necessários. A vacinação, explicávamos e
aplicávamos no próprio parque. Fazíamos reuniões mensais com as mães
para falar sobre a situação da criança lá ou algum problema. (SANTOS, M.,
2005, p. 253)

Uma hipótese para o processo de matrícula/ingresso nas instituições de Ribeirão Preto é a divulgação pela própria população dos bairros, o chamado "boca-a-boca". O rádio, que já era utilizado nas casas em meados dos anos 50, também pode ter sido um instrumento de divulgação do atendimento às crianças.

É necessário agora compreender o contexto de implantação de cada parque, seus usuários e a sua organização para analisar, por fim, se os parques infantis ribeirão-pretanos realmente contemplaram as necessidades da classe popular. Para que possamos realizar essa investigação, trataremos de cada parque municipal, destacando suas características observáveis nas pesquisas documentais pela cidade. Vale destacar que, neste movimento, o Arquivo Municipal e a Secretaria de Planejamento Urbano da cidade contribuíram de maneira fundamental com o acesso aos documentos, plantas e legislação sobre os parques infantis ribeirão-pretanos.

\subsection{1 - Parque Infantil Peixe Abbade}

O Parque Infantil Peixe Abbade é aquele que, anteriormente, consideramos como Parque Infantil do Barracão. Cumpre esclarecer que o uso de ambas denominações é justificada pelo fato de que popularmente, a instituição foi chamada desde o início de "Barracão" devido ao bairro em que se localizava e que o nome "Peixe Abbade" foi adotado a 
partir da Lei Ordinária $\mathrm{n}^{\circ}$ 443, elaborada em 5 de novembro de 1955 (RIBEIRÃO PRETO, 1955b), em homenagem ao Promotor Público Dr. José de Almeida Peixe Abbade, que atuou na cidade. Uma observação a ser feita sobre essa Lei se refere ao fato de que o sobrenome "Abbade" foi grafado como sendo "Albade", o que dificulta a pesquisa na base de dados da legislação municipal.

Analisando sua localização a partir dos subsetores indicados acima, podemos concluir que se situava no subsetor O-6, onde estão, segundo o Decreto n 333 (RIBEIRÃO PRETO, 1983), os atuais bairros: Ipiranga (parte), Vila Amélia, Sumarezinho, Vila Recreio (parte), Alto do Ipiranga, Vila Prado e Vila Esmeralda.

A investigação realizada até aqui indica que a influência do Departamento de Educação Física do Estado de São Paulo foi mais incisiva no processo de implantação deste parque, pois, como citamos anteriormente, os documentos oficiais expressam uma clara ligação entre a Prefeitura e o DEF-SP nos assuntos voltados para o Parque do Barracão.

Uma notícia do jornal A Cidade, em 22 de agosto de 1950 indica o significado social da obra municipal para o bairro:

É esta a primeira vez na história do município que algo realmente importante vai ser feito para o povo do Barracão, que até hoje vive em ruas sem calçamento e desconhecendo uma série de conforto desfrutado por elementos de outros bairros da cidade. De fato, o Barracão de cima esteve sempre ao abandono. Agora, com a atitude do Dr. José de Magalhães, determinando ali a construção de um parque infantil, aquela grande coletividade, constituída de operários, sem dúvida, estará satisfeita. Seus filhos terão onde brincar e praticar esportes. (A CIDADE, 1950).

Outra notícia, registrada pelo mesmo jornal na data da inauguração do parque ( 8 de dezembro de 1951), descreve o prédio como possuidor de "linhas modernas", situado em uma "área de terra ajardinada, possuindo piscina para crianças, quadras de diversões, brinquedos, etc". (A CIDADE, 1951).

Entre essas publicações, um detalhe chama a atenção: nenhuma delas trata dos aspectos educativos e assistenciais da obra. Em contrapartida, um ofício do Departamento de Educação Física do Estado de São Paulo cumprimentou o prefeito municipal em 19 de dezembro de 1952, sinalizando que esta obra no Barracão "encadeando-se com os que vierem a existir, carreará para a operosa e profícua administração de Vossa Senhoria, o galardão honrosíssimo de ter voltado suas visitas para o sério e inadiável problema da assistência à infância",31.

\footnotetext{
${ }^{31}$ O documento pode ser encontrado no Arquivo Público e Histórico de Ribeirão Preto, na Pasta 229 - caixa 43 setor de protocolo - dossiês - parque infantil.
} 
A figura 5, localizada no Álbum Histórico e Fotográfico dos Postos Odontológicos do Serviço Dentário de Ribeirão Preto nos dá uma noção importante acerca da estrutura física e da grandiosidade do Parque Infantil do Barracão.

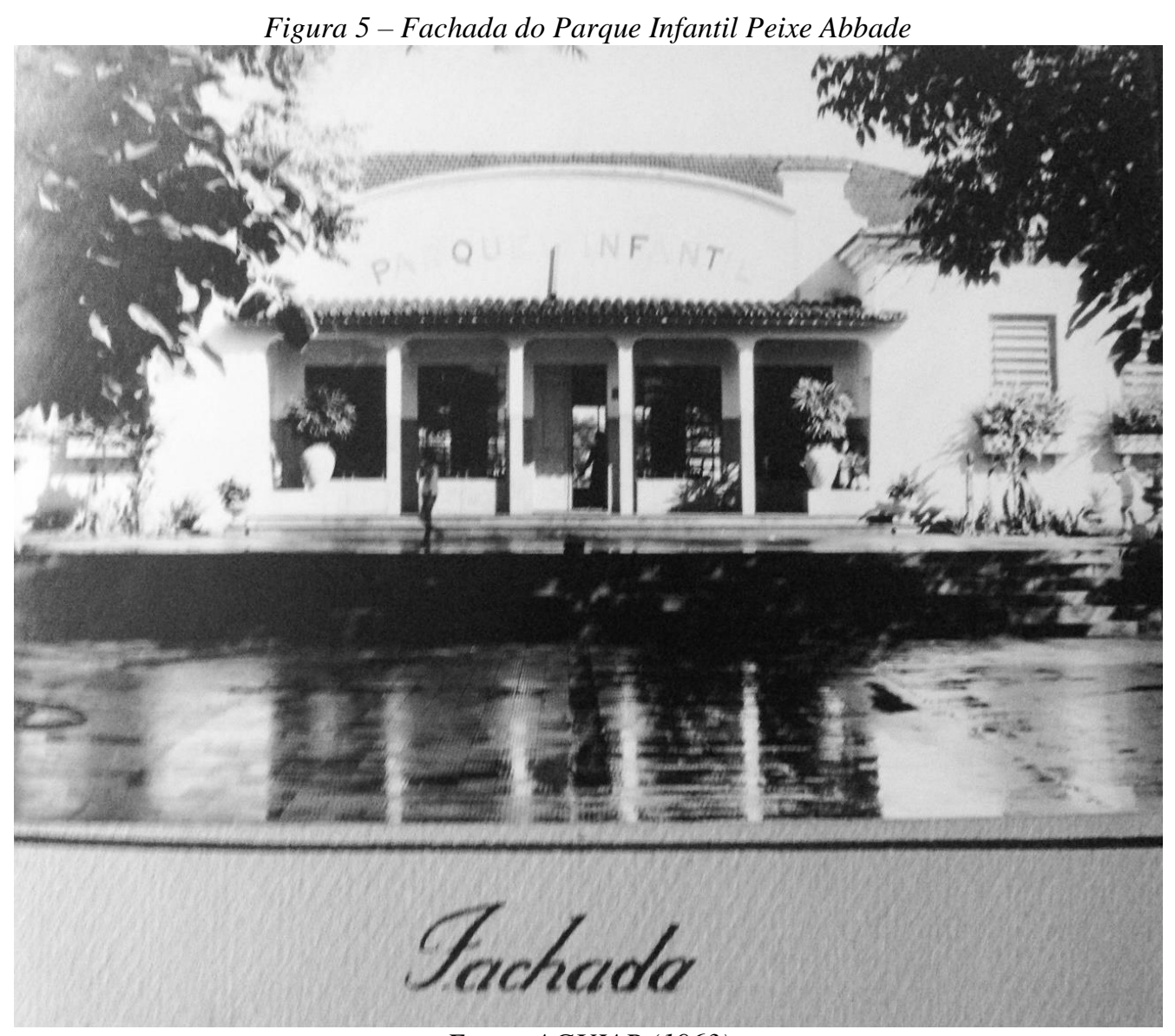

Fonte: AGUIAR (1963)

Com a inauguração realizada nos fins de 1951, o parque parece ter iniciado suas atividades imediatamente - um indício desta hipótese é o documento escrito pelo Inspetor Escolar do Departamento de Cultura do Estado de São Paulo, Plínio Travassos dos Santos ${ }^{32}$, para o então Prefeito Condeixa ${ }^{33}$. Devido ao conteúdo altamente revelador, aqui será transcrito parte do documento:

Sem a menor intervenção e conhecimento deste Departamento, foi escolhido o local, confeccionada a planta, lançada a "pedra fundamental" e instalado o Parque Infantil do Barracão, cuja inauguração teve lugar no dia 8 de dezembro, apesar de não ter sido estruturado em lei, pelo que seu

\footnotetext{
${ }^{32}$ Plínio Travassos dos Santos foi secretário da Câmara Municipal e funcionário da Prefeitura, inspetor escolar e o primeiro diretor do Departamento de Cultura, além de atuar como advogado, jornalista e escritor. (ESPÍRITO SANTO, 2010).

${ }^{33} \mathrm{O}$ documento pode ser encontrado no Arquivo Público e Histórico de Ribeirão Preto, na Pasta 14 - inventário educação.
} 
funcionamento está sendo feito irregularmente, se bem que prestando otimós serviços, graças à dedicação do seu corpo docente. Naturalmente, por falta de aludida lei, o corpo docente, arbitrariamente constituído, possui apenas 5 professores, sendo 2 estaduais, comissionados, e 3 municipais, nomeadas estas para escolas municipais cujo funcionamento está suspenso. [...] Com este diminuto pessoal [...], funciona o Parque em dois períodos diários - das 8 às 11 e das 14 às 17 - quando o natural será seu funcionamento em período de 4 horas, tendo para cada um corpo docente especial, pois, como é evidente, muito fatigantes são os trabalhos reclamados das professoras, obrigadas que são a interrupta atividade. Além disso, indispensável é, pelo menos, uma professora substituta, capaz, para substituir qualquer professora quando faltar.

Em seguida, Plínio afirma que o parque não pode receber a capacidade de 400 crianças (200 em cada período), devido ao fato de que não houve um fornecimento de uniformes adequado aos mais necessitados e, por fim, agradece o interesse revelado por Condeixa em relação aos trabalhos do Departamento de Cultura desde seu segundo dia de mandato, quando foi visitar as instalações do mesmo e elogia as providências que o prefeito vinha tomando em prol do melhoramento do parque ${ }^{34}$.

Apesar de estar sem data, um ofício da Pasta 229 (Parque Infantil) do Arquivo Municipal indica que a Lei de criação do parque do Barracão foi promulgada pelo próprio Condeixa, com seis artigos que muito dizem sobre o funcionamento da instituição. No primeiro, fica explicitado que o regime ali adotado seria semelhante ao dos parques espalhados pelo Estado (que, como vimos anteriormente, eram orientados pelo DEF-SP); o segundo artigo se refere ao quadro docente (composto por uma diretora e mais cinco professoras, comissionadas do Estado ou aproveitadas do quadro do magistério municipal); o terceiro define que serão necessárias quatro diaristas; o quarto institui que o serviço médicodentário seria responsabilidade do Departamento da Saúde da prefeitura; o quinto determina que "se conviér à Prefeitura, poderá receber orientação do DEF-SP que, nesse caso, fará a indicação de uma professora do Estado para exercer, em comissão, o cargo de Diretora" (o parágrafo único referente a este artigo indica que, neste caso, os vencimentos da Diretora ficarão a cargo do Estado); por último, o artigo sexto autoriza a prefeitura a realizar as "necessárias operações de crédito" para a manutenção do parque e o pagamento do pessoal.

Sobre as atividades realizadas em seu interior, Darahem (2011) afirma que as professoras, além de auxiliarem as crianças com as lições de casa - já que muitas delas, tendo entre 7 e 12 anos, frequentavam a escola regular no período oposto ao parque -, recebiam treinamento específico para desenvolver atividades físicas com as turmas. Além disso, por

\footnotetext{
${ }^{34}$ O documento pode ser encontrado no Arquivo Público e Histórico de Ribeirão Preto, na Pasta 14 - inventário educação.
} 
meio de entrevistas com professoras que atuaram nas instituições parqueanas, Darahem (2011) esclarece que quanto menor era a idade das crianças, menor era a quantidade nas turmas, chegando a 40 alunos nos grupos mais velhos.

Sobre a quantidade de crianças que frequentavam a instituição, uma notícia publicada em 7 de abril de 1953 pelo jornal A Tarde explicitou: "800 crianças no Parque Infantil do Barracão: um espetáculo que precisa ser visto pelos ribeirão-pretanos - recuperação da infância no nosso bairro". (A TARDE, 1953). O Álbum Comemorativo do $1^{\circ}$ Centenário de Ribeirão Preto define que em março de 1956, estavam matriculadas 2.156 crianças, mas que a frequência era de 400 - indício de que a presença na instituição era bastante volante. Em 1965 , entretanto, segundo um documento ${ }^{35}$ no atendimento era de 420 crianças.

Uma das depoentes do trabalho de Ferreira (2010) fala sobre a realidade econômica das crianças do Parque Infantil do Barracão:

No parque não tinha criança rica. Era pobre mesmo. É periferia mesmo. É pobre mesmo. Lá do campo aberto, aqui dos campos elísios, vila Tibério....que rico! Mas de jeito nenhum! Até uniforme tinha que dar....tinha uma alimentação excelente...uma alimentação excelente. Agora, os ricos, minha filha, estudavam em escola particular, né Débora? Eles freqüentavam clube, evidente, né? Pra recreação deles eram clube particular...recreativa, regatas....de nível social um pouco mais alto.Isso daí...(FERREIRA, 2010, p. 44).

A figura 6 apresenta uma das atividades desenvolvidas no parque infantil com as crianças: a aula de música.

\footnotetext{
${ }^{35}$ O documento pode ser encontrado no Arquivo Público e Histórico de Ribeirão Preto, na Pasta 32 - inventário educação.
} 


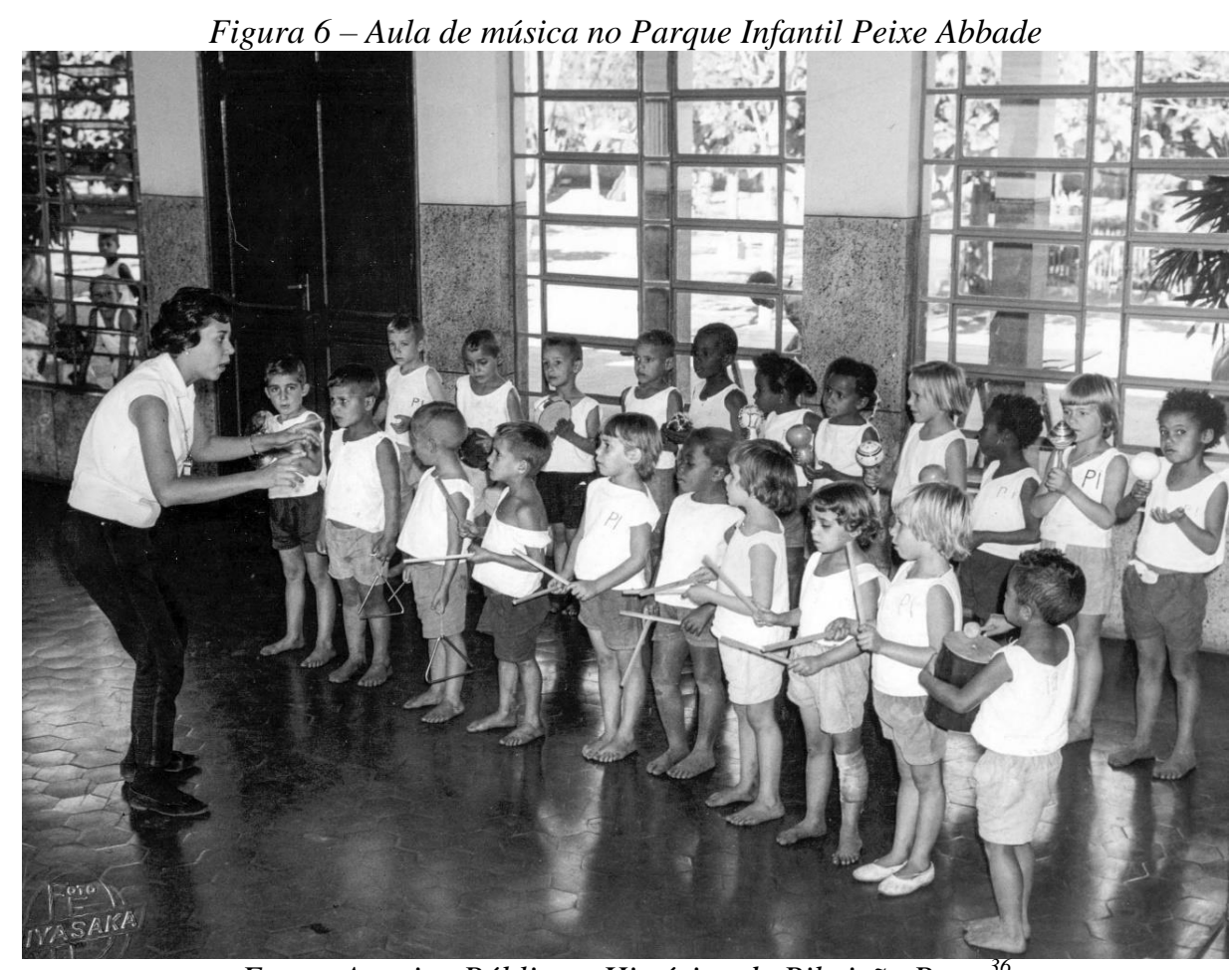

Fonte: Arquivo Público e Histórico de Ribeirão Preto ${ }^{36}$

Os Jornais analisados no período de funcionamento do parque revelam que periodicamente a instituição recebia doações da iniciativa privada ou promovia eventos para angariar fundos. Em 21 de março de 1953, uma Campanha promovida pelo jornal A Tarde arrecadou dinheiro com os calouros da Faculdade de Farmácia e Odontologia da Universidade de São Paulo, 140 latas de leite condensado com senhoras da cidade e 140 latas de Vic Maltema com o Delegado regional do SESI - autoridade que, no evento de entrega dos donativos, afirmou, no jornal A Tarde em 18 de março de 1953, que era preciso "recuperar as crianças sub-nutridas do bairro do Barracão".

Em 1958, segundo dados apresentados no Álbum Histórico e Fotográfico dos Postos de Odontologia do Serviço Dentário Municipal (AGUIAR, 1963), o prefeito Condeixa passa a aproveitar a clínica instalada nos parques para o atendimento noturno aos adultos que precisavam extrair dentes e não possuíam recursos. Sendo assim, a clínica que já funcionava durante o dia recebendo crianças matriculadas na instituição desde sua inauguração, em 1951, passou a funcionar também de noite.

Em relação às ações de assistência, o depoimento de uma ex-professora do parque do Barracão registrado no trabalho de Ferreira (2010, p. 45), é bem revelador:

\footnotetext{
${ }^{36} \mathrm{O}$ documento pode ser encontrado no Arquivo Público e Histórico de Ribeirão Preto, no fundo Cel. Alfredo Condeixa Filho, na Pasta 66, nº de registro 731.
} 
No parque, era a coisa mais interessante...as crianças vinham tão sujinhas! A gente catava essas crianças, colocava...porque tinha banheiro, né? Dava banho, dava uniforme, alimentação...eram crianças carentes, bem! Quando não, vinham com aquela...Porque tinha enfermeira e médico. Era uma assistência maravilhosa, viu? Nos parques...excelente. Tinham tudo! Então...num sei quantas e quantas vezes...[...] É um bicho que infiltra na pele...nossa! Quanto berne que eu e a Matilde...que era enfermeira e já é falecida...tiramos de cabeça de crianças, da barriga. O Dr. João Garcia, ele faleceu há pouquíssimo tempo aqui em Ribeirão...era um pediatra maravilhoso...certo? Então...Tinha uma assistência excelente. Então, na convivência com eles...era aquela carência, bem. Porque era...quando o pai e a mãe trabalhavam tudo bem, certo? Mas era uma pobreza tremenda, eles não tinham o que comer. Comiam no parque as crianças. Não era fácil, não.

Uma notícia do jornal A Cidade em 27 de fevereiro de 1977 revelou que o local "tornou-se ponto de encontro de casais suspeitos" e, por isso, um vereador da cidade solicitou junto à Câmara uma reserva da praça para a recreação tanto das crianças frequentadoras do parque, quanto das crianças que estavam no ginásio do bairro. No mesmo ano, outra notícia mostrou em 14 de agosto que, alertadas por professoras, muitas mães estavam procurando por políticos e pessoas influentes para impedir o fechamento do parque. Neste período, já havia registro de corte de verba para a alimentação das crianças.

Em 24 de dezembro de 1980, o Ato 3889 promove a fusão entre a instituição "Peixe Abbade" (já considerada nesse período como escola básica de $1^{\circ} \mathrm{Grau}$ ) e a escola municipal de $1^{\circ}$ Grau "Professor Alfeu Luiz Gasparini". Nessa fusão, o nome adotado seria o mesmo da escola municipal e sua localização seria fixada "entre a Avenida Dom Pedro I e as Ruas Rio Grande do Sul, Pará e Rebouças” (RIBEIRÃO PRETO, 1980b). Assim, o Parque Infantil Peixe Abbade deixava, oficialmente, de existir na cidade.

\subsection{2 - Parque Infantil do Bosque}

Em 13 de novembro de 1952, o jornal A Tarde anunciou, em nota, que o segundo parque infantil da cidade seria implantado antes do Natal, para usufruto das crianças dos bairros Vila Paulista e do Jardim Paulista. Em 13 de janeiro do ano seguinte, outra notícia tratava de uma campanha de arrecadação de fundos em benefício do parque infantil, cuja iniciativa partia da escola estadual do bairro. (FINCOTI, 2012). Um mês depois (em 28 de fevereiro), a terceira notícia encontrada sobre a instituição afirmava que a obra ainda estava em andamento, “em estilo moderno, eficiente e prático". (A TARDE, 1953). Em maio, o jornal A Tarde noticiou em 16 de abril que finalmente a inauguração foi concretizada: 
Não faz muito tampo, noticiamos a providência que estava sendo estudada pelo prefeito Condeixa Filho, em favor das crianças da Favela do Tanquinho e hoje podemos anunciar que essa providência será concretizada, no próximo mês de maio, data marcada para a inauguração do Parque Infantil recém construído pela prefeitura no Bosque municipal, ao lado do local em que até pouco funcionou o "playground". As crianças da Favela do Tanquinho frequentarão o Parque Infantil do Bosque, onde terão assistência médica e dentária, além de Alimentação dietética tão necessária para tirá-los da subnutrição em que se encontram. O transporte das crianças faveladas será feito diariamente por Meio de caminhões da prefeitura, passando elas o dia todo no Aprazível logradouro. Sem dúvida de que se trata de medida digna de destaque, dado o Caráter humanitário de que se reveste. (A TARDE, 1953).

$\mathrm{Na}$ figura 7, pode-se observar os aspectos da estrutura do parque (grande área verde, piscina) e o grupo de crianças atendido (diferentes faixas etárias).

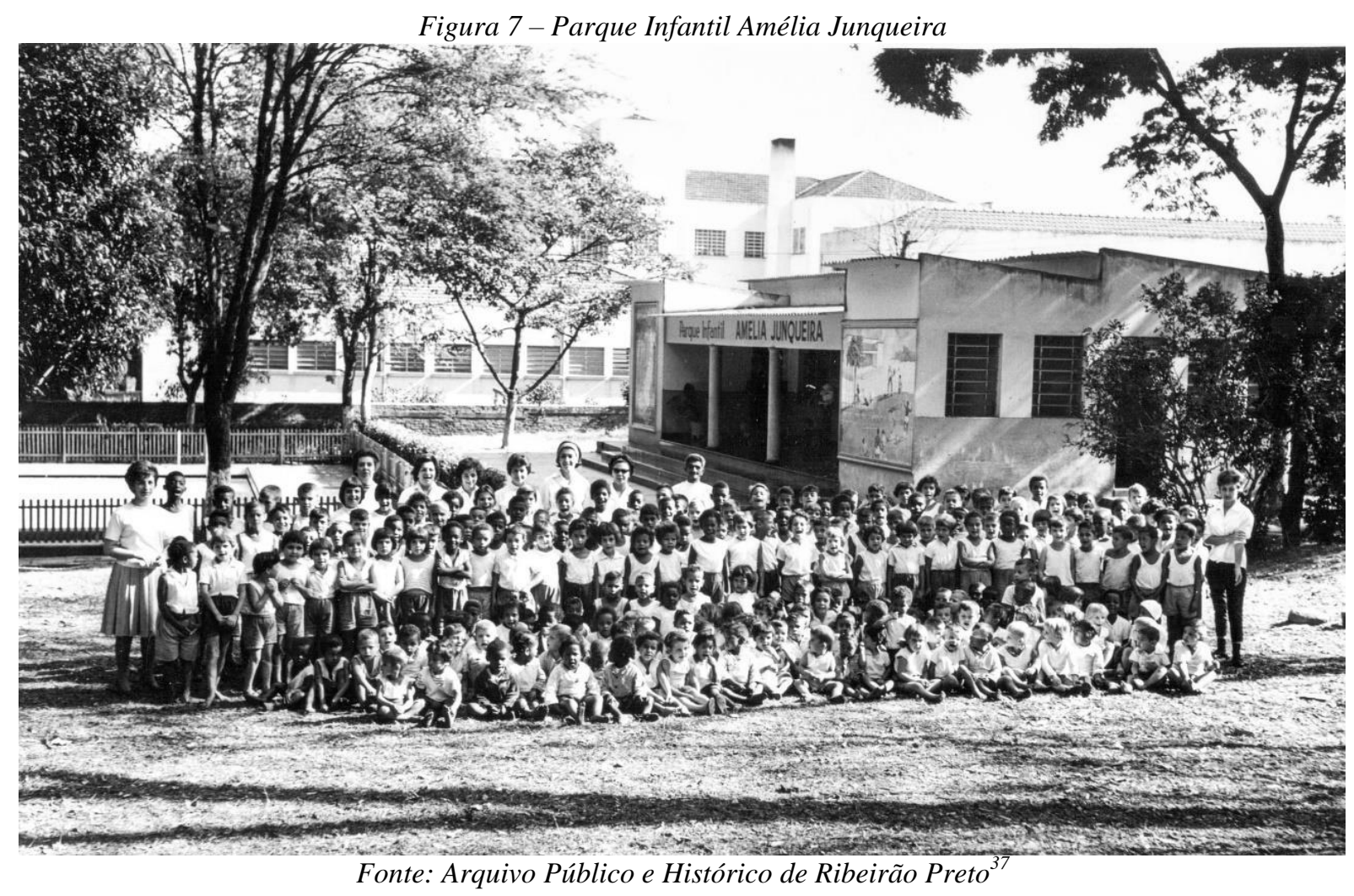

Inaugurado no interior do Bosque Municipal em maio de 1953, o parque infantil teve sua Lei de criação no 333 (RIBEIRÃO PRETO, 1953) publicada em 11 de novembro do mesmo ano, onde constavam alguns elementos acerca de sua estrutura:

Artigo $1^{\circ}$ - Fica criado no prédio próprio do "Bosque Fábio Barreto", o Parque Infantil Municipal, que funcionará sob o mesmo regime dos congêneres estaduais, notadamente no que diz respeito à férias, especialização ou estágio dos professores.

\footnotetext{
${ }^{37}$ O documento pode ser encontrado no Arquivo Público e Histórico de Ribeirão Preto, no fundo Cel. Alfredo Condeixa Filho, na Pasta 87, $\mathrm{n}^{\circ}$ de registro 1080.
} 
Artigo $2^{\circ}$ - O Parque Infantil terá um corpo docente mínimo de 6 (seis) professores especializados no assunto e nomeados por concurso.

$\S 1^{\circ}$ - A direção será exercida por professora municipal ou estadual, mediante uma gratificação de $\mathrm{Cr} \$ 1.000,00$ (hum mil cruzeiros) mensais.

$\S 2^{\circ}$ - No presente ano, a Prefeitura Municipal poderá aproveitar os atuais professôres municipais, cujas escolas não estejam funcionando normalmente para as atividades docentes do Parque Infantil Municipal.

$\S 3^{\circ}$ - Poderá em qualquer tempo, a Prefeitura Municipal aceitar a colaboração dos professores estaduais especializados, sem ônus para o município, exceto quando exercendo-a função de direção.

Artigo $3^{\circ}$ - Além dos professores acima referidos, contará o Parque Infantil com mais 4 (quatro) diaristas.

Artigo $4^{\circ}$ - O serviço médico dentário do Parque Infantil ficará a cargo da Assistência Médico-Escolar do Departamento de Saúde da Prefeitura.

Artigo $5^{\circ}$ - O Parque, se convier à Prefeitura, poderá receber orientação do Departamento de Educação Física do Estado que, nêsse caso, fará a indicação de um professor do Estado para exercer, em comissão, o cargo de Diretor.

$\S$ Único - Nessa hipótese, os vencimentos do Diretor ficarão a cargo exclusivo do Estado.

Artigo $6^{\circ}$ - As despesas decorrentes da presente lei correrão por conta das verbas próprias a serem consignadas nos futuros orçamentos. (RIBEIRÃO PRETO, 1953).

Sobre tal Lei, é possível aferir a orientação do DEF-SP no Artigo $1^{\circ}$ - que define o funcionamento do parque do Bosque a partir dos mesmos princípios dos demais parques do Estado - e no Artigo 5. A questão das despesas, especificada no Artigo 6, justifica a existência das inúmeras campanhas de arrecadação de verba que foram registradas durante o período de funcionamento deste e de outros parques municipais.

Em relação ao nome do parque, Darahem (2010) explica que a família Junqueira tinha muito prestígio na cidade devido à sua atividade cafeeira e a sua cultura, influenciada pelas frequentes viagens à Europa. As mulheres realizavam benfeitorias e se envolviam em projetos sociais voltados para crianças e, por isso, algumas delas foram homenageadas pelas escolas municipais. Sobre o ano em que o parque deixou de ser denominado "do Bosque" para tornarse "Amélia Junqueira", não há referências.

Sua localização corresponde ao subsetor L-2, onde estão os bairros Jardim Paulista, Jardim Paulistano, Jardim Macedo, Jardim Palma Travassos, Vila Angélica, Jardim das Pedras, Vila Claudina, Vila Paulista e parte do Parque dos Bandeirantes. (RIBEIRÃO PRETO, 1983).

Sobre a Vila Paulista, uma reportagem de 27 de outubro de 1949, do jornal Diário de Notícia revela: "um dos mais belos recantos da cidade, é um atestado da capacidade realizadora do ribeirão-pretano. Situada em lugar privilegiado, aquele bairro tem progredido de uma maneira notável". (DIÁRIO DE NOTICIA, 1949). 
Professoras deste parque entrevistadas por Darahem (2011) contam que a instituição possuía um refeitório, uma sala destinada à Diretora e uma sala de atendimento odontológico - não havia, portanto, nenhuma sala de aula e as turmas eram colocadas debaixo das árvores quando as professoras desejavam desenvolver alguma atividade de registro.

No Natal de 1954, foram distribuídos 3.200 brinquedos para as crianças do Parque Infantil do Bosque. Considerando que em 1956, segundo o Álbum Comemorativo do $1^{\circ}$ Centenário de Ribeirão Preto (SOUZA, 1956), 170 alunos frequentavam a instituição diariamente, nota-se que o número de brinquedos foi bem alto. $\mathrm{Na}$ ocasião, estiveram presentes, de acordo com o jornal Diário da Manhã de 25 de dezembro de 1954, o prefeito, “elementos representativos da sociedade local, jornalista, radialista e outras pessoas gradas". (DIÁRIO DA MANHÃ, 1954).

Uma depoente da pesquisa de Ferreira (2010) que trabalhou na instituição em meados dos anos 1960 respondeu, ao ser questionada sobre o convívio entre os pais e as crianças parqueanas: "Não, não. Muito difícil. Quase num tinha porque trabalhavam o dia todo, né? Lá no Bosque o caminhão que levava as crianças. Levava de manhã e voltava a tarde...alguns vinham a pé, né? Então quase num via.”. (FERREIRA, 2010).

A variedade de atividades realizadas com as crianças no Parque Infantil do Bosque se expressa em uma lista de materiais que a diretora deste parque elaborou para o ano de 1964. Entre jogos, elementos para a produção de trabalhos manuais, tintas e papeis, foram solicitados mais de 50 itens - à prefeitura, provavelmente ${ }^{38}$.

Em 15 de julho de 1955, uma reportagem do jornal Diário da Manhã informa que uma reunião do "Curso de Fundamentos e Técnicas de Recreação" seria realizada no Parque Infantil do Bosque, onde também estariam presentes as crianças matriculadas naquela instituição; entre as atividades previstas, destacam-se as rodas dramatizadas, os jogos cooperativos e as aulas historiadas. Isso mostra que o parque também funcionava como um espaço de formação profissional - o que não está explícito, neste caso, é o papel do DEF-SP no oferecimento do Curso em questão.

Sobre o atendimento do Parque do Bosque, duas fontes explicitam a importância desta instituição: em primeiro lugar, uma nota do Diário da Manhã de 4 de maio de 1961 onde a quantidade de refeições oferecidas pelo parque no mês de abril é publicada (6.949 almoços, 5.847 jantares e 6.916 lanches $^{39}$ ); em segundo lugar, um documento datado em 12 de março

\footnotetext{
${ }^{38} \mathrm{O}$ documento pode ser encontrado no Arquivo Público e Histórico de Ribeirão Preto, na Pasta 35 - inventário educação.

${ }^{39}$ Se considerarmos que o mês de abril teve 20 dias úteis, a quantidade diária de refeições servidas seria de aproximadamente 347 almoços, 292 jantares e 345 lanches.
} 
de $1965^{40}$ indica que o número de crianças frequentadoras do Parque do Bosque girava em torno de 350.

Souza (1963) relatou os atendimentos realizados nas instalações do Parque Infantil do Bosque: nele, consta que a Clínica diurna foi instalada em junho de 1953 pelo prefeito Condeixa e que se destinava ao tratamento dentário das crianças matriculadas na instituição; já a Clínica noturna, teve suas atividades iniciadas em 1961 e recebia os funcionários da prefeitura e seus familiares (figura 8). Em 1963, entretanto, algumas mudanças ocorreram: de dia, as crianças do curso primário do Ginásio dos Campos Elísios também passaram a receber atendimento e, de noite, a Clínica passou a atender a população em geral daquele bairro, tal como os alunos do Ginásio noturno. (PRANDI, 2015).

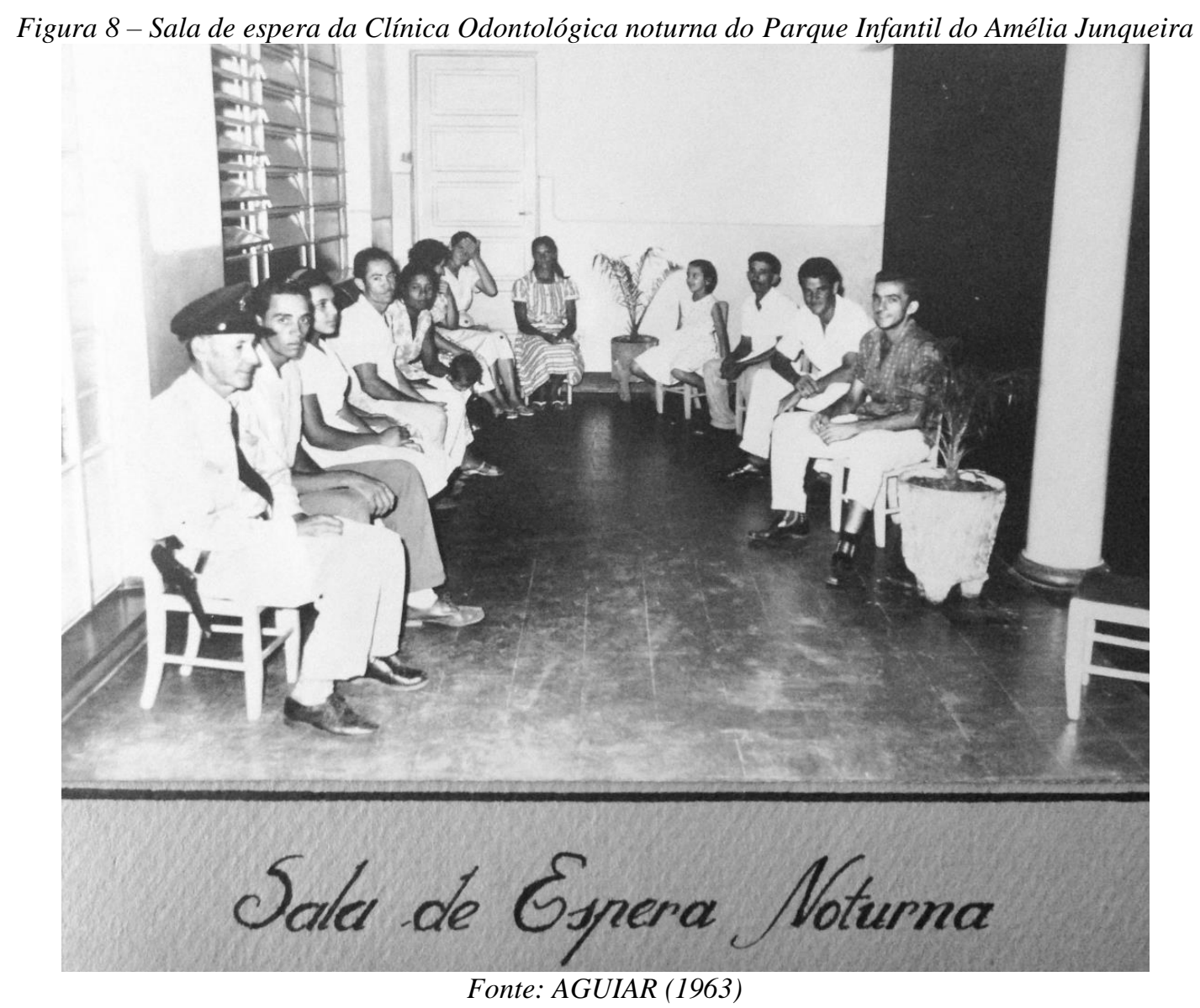

No mesmo ano de 1965, uma nota do jornal Diário da Manhã de 13 de abril, trata da comemoração da páscoa pelos alunos do parque, organizada pela então diretora Doracy Chúfalo Patrick: "inúmeras atrações serão oferecidas a garotada" - entre elas, um almoço e a distribuição de refrigerantes. (DIÁRIO DA MANHÃ, 1965). Além desta festividade, no

\footnotetext{
${ }^{40} \mathrm{O}$ documento pode ser encontrado no Arquivo Público e Histórico de Ribeirão Preto, na Pasta 32 - inventário
} 
mesmo mês de abril, a diretora e as professoras do referido parque organizaram uma campanha de arrecadação de dinheiro para a compra de agasalho para as crianças do parque. O sorteio da "reunião-almoço" correu pela Loteria Federal e, segundo a nota de 30 de abril de 1965 do Diário da Manhã, a prenda seria entregue na casa do ganhador. Em 23 de maio, outra realização da diretora Doracy virou notícia: em parceria com os auxiliares e funcionários do parque, foi organizada uma festa "animada com doces e balas para todos os presentes" para a entrega dos novos uniformes e agasalhos às crianças do parque. (DIÁRIO DA MANHÃ, 1965).

Devido à transformação do parque infantil municipal em escola parqueana vocacional (alteração realizada durante a gestão de Welson Gasparini), em 28 de maio de 1965, a instituição recebeu a visita do Dr. Alfeu Gasparini - Diretor do Departamento de Educação e Cultura de Ribeirão Preto. Tal acontecimento virou notícia no jornal Diário da Manhã.

No Bosque, eram problemas frequentes a invasão de animais de diferentes portes nos espaços destinados às crianças e a queda das árvores. Por esse motivo, em 1989, o parque infantil passou a funcionar na Avenida Treze de Maio. (DARAHEM, 2011).

Na figura 9, de setembro de 1961, é possível observar a quantidade de árvores que rodeava a quadra utilizada pelas crianças.

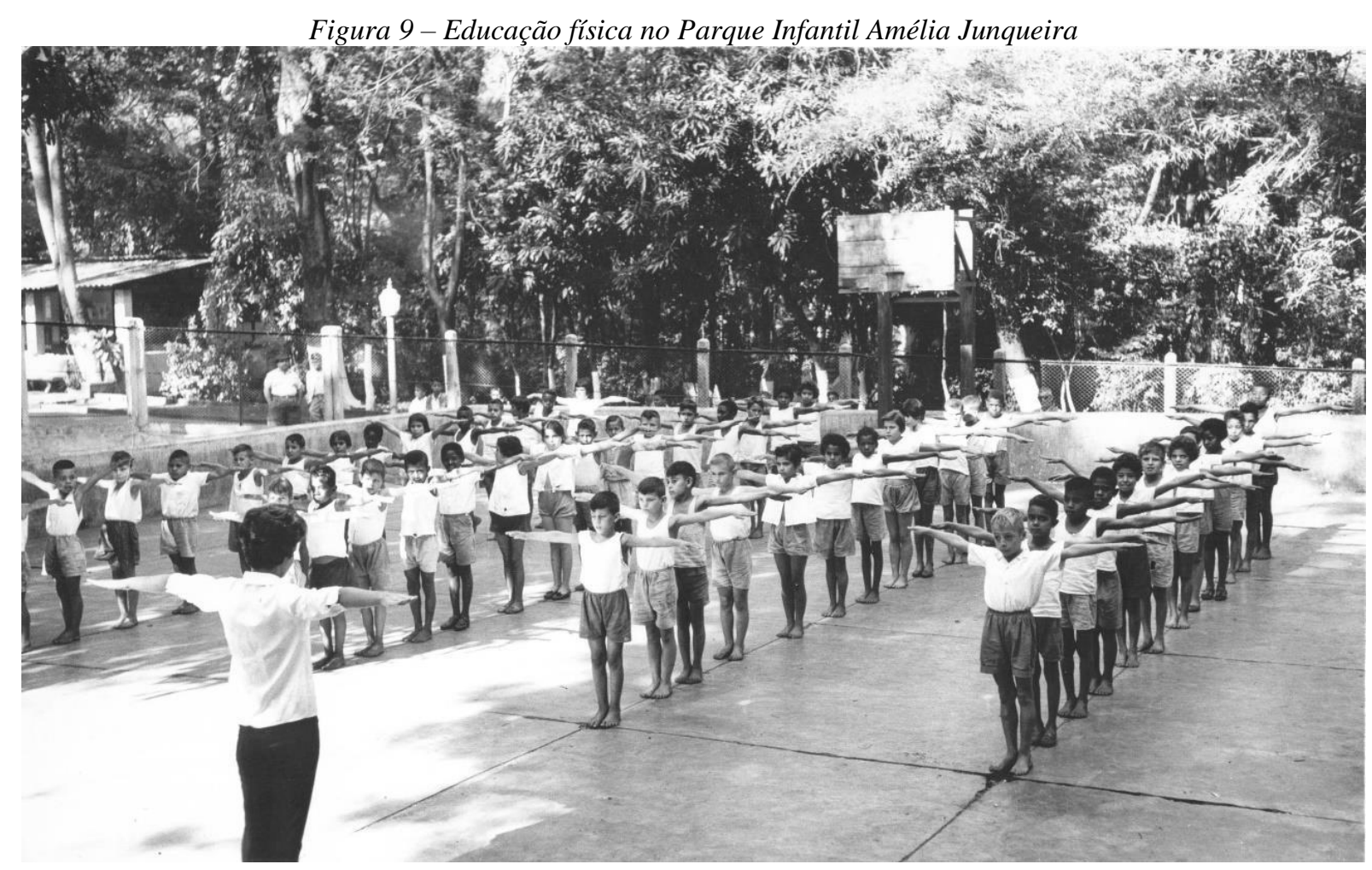


Um acontecimento polêmico marcou a história do parque do Bosque: foi o caso das crianças intoxicadas, registrado em outubro de 1972. Segundo reportagem do jornal O Diário da Manhã, em uma Comemoração da Semana da Criança foi servido um almoço e um bolo que, provavelmente, tinham ingredientes estragados. Das 280 crianças presentes, 40 foram para o hospital após apresentarem vômitos e até desmaios. O prefeito Antônio Duarte Nogueira insinuou para a imprensa que a instituição poderia ter sofrido uma sabotagem.

Por meio dos documentos encontrados no Arquivo Público Municipal, nota-se que a Semana da Criança era bastante comemorada no interior dos parques. Um material (escrito à mão) encontrado na Pasta "Relatórios dos Parques Infantis - 1965", mostra que entre as atividades previstas para esta semana no parque Amélia Junqueira estavam: dança, natação, excursão, exposição de trabalhos manuais, bandinha, distribuição de pepsi-cola, inauguração de atividades de horticultura, seleções de roda, ping-pong, distribuição de sorvetes, corrida, brincadeira com bexiga, dramatização, jogral (tema: a criança que trabalha), gincana, queimada, sorteio de uma caixa de meias, alimentação variada - arroz dôce, canjicada, creme de maisena, sanduiches, refrescos e guloseimas em geral.

\subsection{3 - Parque Infantil da Vila Tibério}

\footnotetext{
${ }^{41}$ O documento pode ser encontrado no Arquivo Público e Histórico de Ribeirão Preto, no fundo Cel. Alfredo Condeixa Filho, na Pasta 51, nº de registro 586.
} 


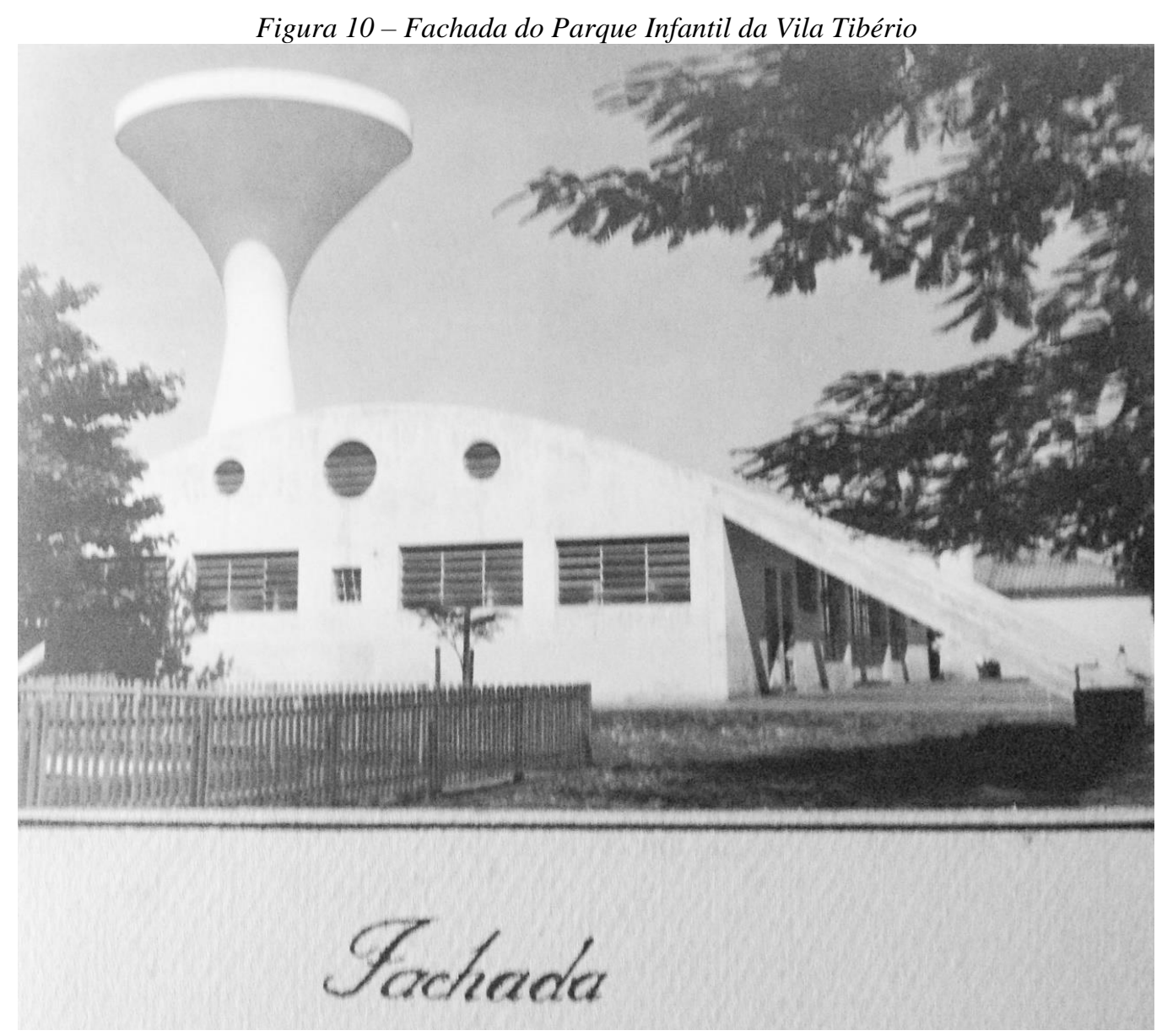

Fonte: AGUIAR (1963)

De acordo com o Fundo "Escolas Municipais" da Secretaria de Planejamento da cidade, o parque em questão (figura 10) foi inaugurado em 8 de dezembro de 1954 numa região que atualmente corresponde ao subsetor O-2 - mas especificamente na Rua Aurora, cujos bairros são discriminados pelo Decreto no 333 de 26 de dezembro de 1983 (RIBEIRÃO PRETO, 1983): Vila Tibério, Vila Amélia Junqueira, Jardim Maria Augusta, Vila Uchôa, Vila Formosa, Vila Anésia, Vila Aurora, Jardim Conceição Vila Manoel Junqueira, Vila Balbina, Vila Antônio de Oliveira, Vila Joaquim Nabuco.

Em 11 de abril de 1951, um documento localizado na Pasta 229 do Arquivo Municipal revela uma comunicação entre o DEF-SP e o então Prefeito José de Magalhães onde o primeiro envia em anexo (devido a uma solicitação de Magalhães) uma lista de material necessário ao Parque Infantil da Vila Tibério que, segundo o próprio documento, já estava em construção. Além disso, o ofício objetiva comunicar que o projeto deste parque já estava sendo executado pelo DEF-SP. Essas informações são reveladoras para o entendimento do processo de implantação desta instituição, pois demonstram que, mesmo sem o projeto do 
DEF-SP, a construção foi iniciada pela Prefeitura, que solicitou ao Departamento apenas a relação de materiais necessários.

$\mathrm{Na}$ Caixa $\mathrm{n}^{\mathrm{o}} 4$ do Inventário Educação mantido no Arquivo Municipal, outro documento trata da mesma instituição: neste, datado em 8 de março de 1952, o Chefe da "Seção de Cadastro e Patrimônio" envia ao Prefeito Alfredo Condeixa Filho o seguinte aviso:

Dando cumprimento as determinações de V.Excia, tenho a honra de comunicar-lhe que para a instalação de um Parque Infantil para o bairro de Vila Tibério, foram feitas as plantas e memórias para a desapropriação por via amigável ou judicial do terreno da Quadra $n^{\circ} 2$ da Vila Antônio Fernandes de Oliveira, com as áreas e as descriminações de seus proprietários.

Relacionando os dois documentos descritos acima, tem-se o indício de que o projeto para o Parque da Vila Tibério foi feito por mais de um órgão.

Um forte indício de que a obra executada foi aquela projetada pela "Seção de Cadastro e Patrimônio" é um Memorial ${ }^{42}$ de 24 de março de 1954, que descreve as características físicas do terreno - informação que se corresponde com a EMEI Anita Procópio Junqueira existente hoje, construída a partir das instalações do parque (Rua 21 de Abril, 570):

Uma gleba de terreno, de forma regular, fechado de cerca viva, de propriedade de quem de direito, com área de 7.901,00 metros quadrados e com as seguintes dimensões pela frente da rua 21 de Abril 87,95 metros lineares; frente da rua Constituição 88,90 metros lineares; frente da rua Aurora 88,90 metros lineares; e frente da rua Alvares de Asevêdo 89,90 metros lineares.

Em termos de legislação, é necessário destacar três Leis Ordinárias relacionadas ao Parque da Vila Tibério: em primeiro lugar, a Lei nº 421 de 20 de junho de 1955 (RIBEIRÃO PRETO, 1955a), assinada por José Costa, que declara como sendo de utilidade pública o terreno destinado ao Parque; em segundo lugar, a Lei ${ }^{\circ} 547$ de 26 de fevereiro de 1957 (RIBEIRÃO PRETO, 1957a) - gestão Costabile Romano -, que determina a criação oficial da instituição, sob as mesmas normas do Parque do Bosque, citado anteriormente; e, por fim, em terceiro lugar, a Lei $\mathrm{n}^{\circ}$ 588, de 17 de agosto de 1957 que altera o nome da instituição para Parque Infantil Anita Procópio Junqueira. (RIBEIRÃO PRETO, 1957b).

É importante considerar que até o atual estágio da investigação, o único jornal onde foram localizadas reportagens sobre este parque foi o Diário da Manhã. Entre aquelas que merecem destaque, tem-se, em 15 de julho de 1955, uma matéria anuncia que o "Parque

\footnotetext{
${ }^{42}$ O documento pode ser encontrado no Arquivo Público e Histórico de Ribeirão Preto, na Pasta 229 - caixa 43 setor de protocolo - dossiês - parque infantil.
} 
Infantil da Vila Tibério é sustentado apenas pela prefeitura", retificando, a pedido do prefeito José Costa, uma informação divulgada anteriormente sobre a cooperação particular que a instituição recebia:

[...] de acordo com os dados oficiais [...] as verbas que foram consignadas no corrente exercício, somam a importância de $\$ 469.818,00$ e de janeiro até esta data, foram dispendidos $\$ 456.615,30$ com o pagamento de diarista, salários às professoras e diretoras, material de consumo, pagamento ao médico e dentista, combustível, pneus e câmaras, peças e acessórios, lubrificantes e reparos em caminhão, aquisição de equipe dentário, refrigerador, despesa com viagem de alunos e professoras à Colonia de Férias. Nessa proporção, a Prefeitura deverá gastar até o fim do ano, cerca de 900 mil cruzeiros, donde se conclui a necessidade de suplementação das verbas, o que já foi solicitado. (DIÁRIO DA MANHÃ, 1955).

Em 5 de março de 1957, é divulgado o número de refeições servidas no parque no mês de fevereiro: 21.563 (número alto se comparado com a quantidade de refeições registradas nos parques do Barracão e do Bosque: 9.365 e 3.295, respectivamente). O que justifica esta grande quantidade de refeições é a alta frequência de crianças nesta instituição, divulgada pelo Álbum Comemorativo do $1^{\circ}$ Centenário da cidade (SOUZA, 1956): 800 crianças - no mesmo período havia, no parque do Barracão, 400 e, do Bosque, apenas 170.

O Movimento do mês de abril de 1961 indica que foram oferecidas 10.053 refeições (3.788 almoços, 3.614 lanches e 2.651 jantares) e realizados 130 cortes de cabelo. Na ocasião do $7^{\circ}$ aniversário da instituição, uma reportagem (de 10 de dezembro de 1961) revela que 500 crianças estavam sendo atendidas pelo parque.

Sobre o atendimento odontológico (figura 11), o Álbum Histórico e Fotográfico dos Postos Odontológicos do Serviço Dentário Municipal de Ribeirão Preto registrou, em 1963, mais de 7 mil atendimentos à crianças no período diurno e 8.510 no período noturno, aos adultos e crianças das Escolas Municipais vizinhas. 
Figura 11 - Crianças esperando para o atendimento dentário no Parque Infantil da Vila Tibério

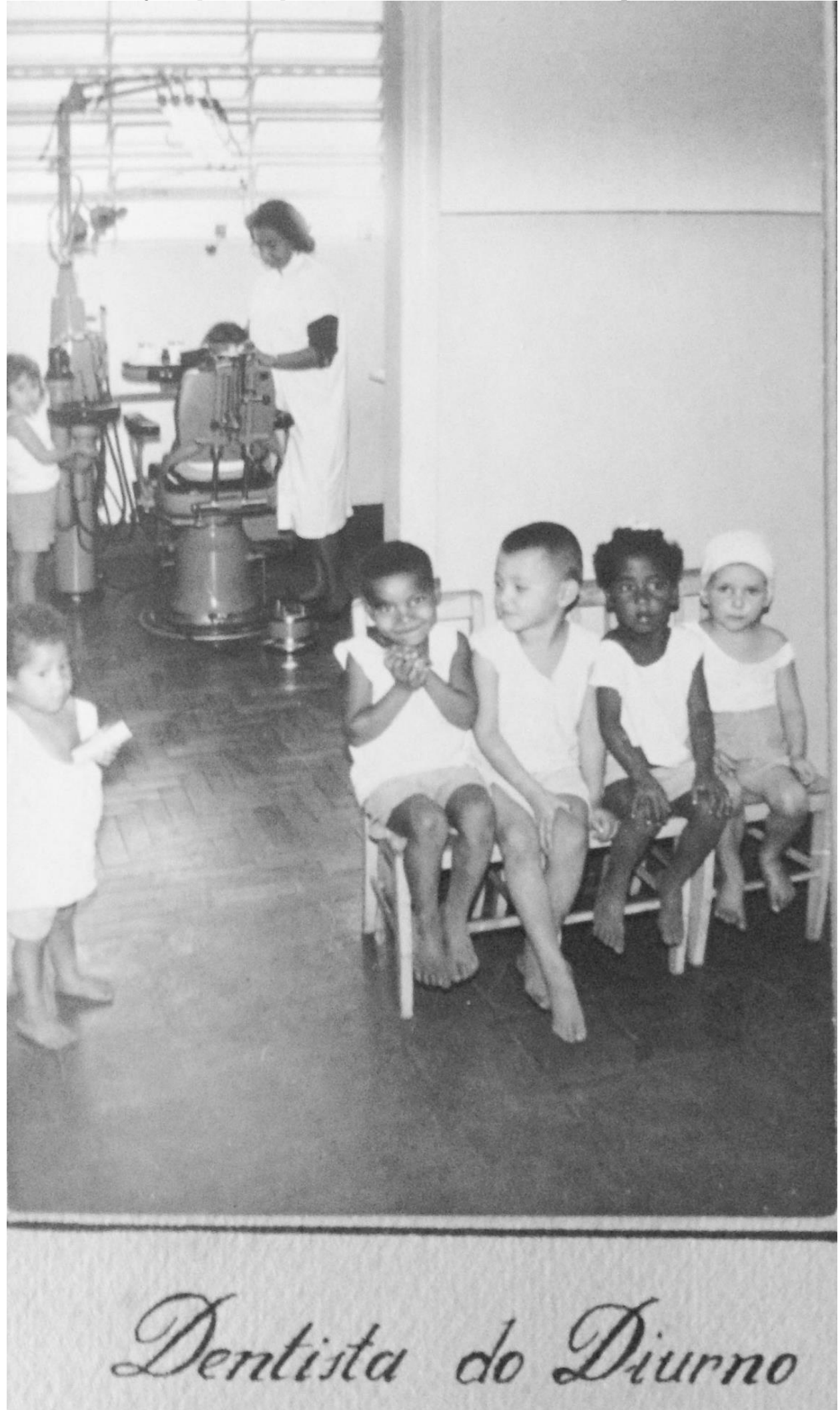

Fonte: AGUIAR (1963)

Analisando os registros acerca da instituição que funcionou na Vila Tibério, encontramos, em 1964, o primeiro evento de caráter religioso promovido em um parque 
municipal: trata-se de uma missa campal em homenagem ao seu $10^{\circ}$ aniversário. Em nota publicada pelo jornal Diário da Manhã em 6 de dezembro, a população da cidade é convidada para prestigiar o evento.

No ano seguinte, a importância do bairro foi expressa por uma iniciativa do jornal Diário da Manhã, que dedicou uma página inteira às questões relacionadas a ele. Entre elas, o abastecimento deficiente de água nas casas e no parque infantil, a necessidade de asfaltamento das ruas e a "algazarra das crianças", que passam o dia jogando bola e atirando pedras com estilingues - sobre esta última, os moradores ouvidos pela reportagem alegaram já ter entrado em contato com os pais e com as autoridades competentes, das quais aguardavam providências.

Em 1965, a compra de uma vitrola portátil para o parque foi divulgada pelo jornal Diário da Manhã, de 8 de julho. Na ocasião, o prefeito Welson Gasparini visitou a instituição para verificar o andamento das atividades. A aquisição foi considerada importante para a "irradiação de contos instrutivos e músicas folclóricas brasileiras", despertando nas crianças o interesse "pela cultura e o amor à Pátria".

É importante considerar que em 1975, segundo o Diário da Manhã de 24 de maio, o Parque Infantil da Vila Tibério contava com uma APM atuante, que chegou a se reunir até com o secretário da Educação e Cultura daquela ocasião, Alfeu Gasparini, para debater problemas relacionados "ao aprimoramento dos alunos". (DIÁRIO DA MANHÃ, 1975).

Na figura 12, o momento da escovação dos dentes - representativo no que se refere à preocupação com os cuidados higiênicos no interior dos parques. 


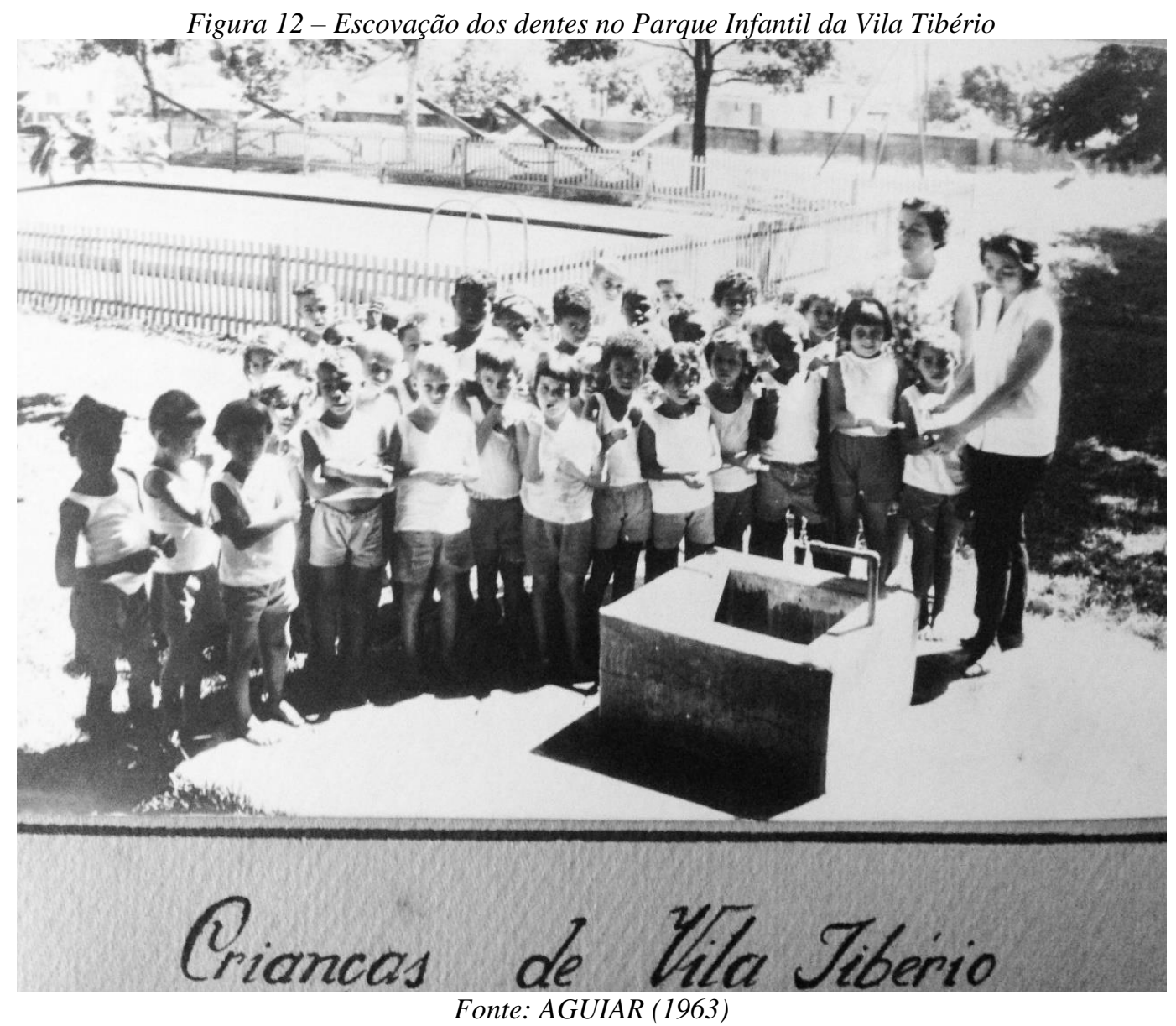

Esta primeira geração de parques infantis instalados em Ribeirão Preto entre 1951 e 1954 representa a consolidação de um modelo de instituição que, parece ter alcançado êxito em sua integração à paisagem escolar pública. As demais unidades construídas na cidade e expostas a seguir, confirmam esta tese.

\subsection{4 - Parque Infantil de Guatapará}

As informações acerca do Parque de Guatapará são mais escassas. Entre as Caixas dos Prefeitos, consta um relatório de 1957 referente à gestão de Costabile Romano que trata da instalação deste parque:

As esferas alcançadas pela esclarecida administração do prefeito municipal Costabile Romano, que, sem favor algum, tem sido uma das mais profícuas de que Ribeirão Preto se ufana, não têm se restringido apenas ao atendimento dos melhoramentos dos serviços públicos do perímetro urbano. Têm alcançado o município, em todos os seus setores, desde o da assistência social, o da remodelação de obras públicas, de vulto até o ensino primário e pré-primário dos Distritos. Ainda no ano passado, atendendo às necessidades do Distrito de Guatapará, o prefeito Costabile Romano criou naquela 
localidade um amplo e bem instalado Parque Infantil, proporcionando às crianças daquele distrito um ambiente sadio e alegre, com um serviço de assistência à altura.

Além disso, uma publicação do Diário Oficial de Ribeirão Preto faz menção a sua existência em 7 de maio de 1959. Aspectos de sua estrutura e localização, entretanto, não foram registrados.

\subsection{5 - Parque Infantil da Vila Virgínia}

Em 10 de março de 1954, a Lei Ordinária no 345 (RIBEIRÃO PRETO, 1954) abriu o crédito do município para a construção do Parque Infantil da Vila Virgínia. Sua data de fundação, entretanto, segundo o Fundo "Escolas Municipais" da Secretaria de Planejamento da cidade consta como sendo 5 de janeiro de 1959.

A demora entre a Lei e a fundação de fato pode ser entendida a partir da análise de um ponto fundamental da legislação: o Artigo $1^{\circ}$ considera que o crédito de Cr\$300.000,00 (trezentos mil cruzeiros), deve ser destinado as despesas da obra do parque infantil, mas que, provisoriamente, o Grupo Escolar da Vila Virgínia é que deverá ser organizado no local. Um indício de que essa articulação realmente ocorreu é a reportagem do jornal Diário da Manhã de 14 de novembro de 1958, onde se afirma que o "Parque Infantil Vila Guanabara vai ter funcionamento efetivo":

Com a transferência anteontem, feita do Grupo escolar Meira Júnior para sua sede própria, em prédio recém-construído na praça Maria Goretti, na Vila Virgínia, foi devolvido à Prefeitura o edifício do Parque Infantil da Vila Guanabara e que desde 1954, estava servindo como estabelecimento de ensino. (DIÁRIO DA MANHÃ, 1958).

O nome "Parque Infantil da Vila Guanabara" foi adotado no período inicial do funcionamento da instituição, já que a mesma foi instalada numa região correspondente ao bairro Jardim Guanabara, segundo o Decreto $\mathrm{n}^{\circ} 333$ de 26 de dezembro de 1983 (que regulamenta os subsetores da cidade). O subsetor correspondente ao parque em questão é o O1, que é composto pelos bairros Vila Virgínia, Vila Bela Vista, D’Elboux (parte), Jardim Piratininga, Vila Izabel, Jardim Jamaica. Loteamento José Pitta, Vila Afonso XIII, Vila Progresso, Vila Liberdade e Jardim Guanabara. (RIBEIRÃO PRETO, 1983).

Em 6 de março de 1959, a Lei no 820 (RIBEIRÃO PRETO, 1959a) determina uma nova denominação para a instituição, seguindo uma prática já adotada em outros parques municipais - de homenagear mulheres conhecidas por seus atos de caridade. Assim, ele 
passou a ser chamado de "Parque Infantil Santa Maria Goretti", nome que permanece identificando o prédio até os dias de hoje, onde funciona como uma Escola Municipal de Educação Infantil.

A última legislação registrada em relação a esta instituição é a Lei $n^{\circ}$ 857, de 18 de setembro de 1959 (RIBEIRÃO PRETO, 1957b) - gestão de Áureo Norberto da Silva -, que autoriza a construção de uma piscina em benefício às crianças frequentadoras deste parque. No mesmo ano, as notícias relacionadas ao movimento escolar demonstram que, no mês de março, foram servidas 16.577 refeições, foram realizados 413 tratamentos dentários e 44 cortes de cabelo, de acordo com o jornal Diário da Manhã de 1959 e no mês de abril, 14.036 refeições e 537 tratamentos dentários, de acordo com o mesmo jornal em 7 de maio.

\subsection{6 - Parque Recanto Quarto Centenário}

O sexto parque infantil instalado no município de Ribeirão Preto se localizava no Distrito de Bonfim Paulista, representado pelo subsetor S-10, onde também estão os bairros Quinta da Alvorada, Royal Park, Bosque das Colinas, Mirante Royal Park, Jd. Emília, Condomínio Ipê Amarelo, Jardim Nova Aliança Sul, Condomínio Bosque dos Jequitibás, Residencial Ipê Roxo, Residencial Ipê Branco, Residencial Aurora Village, Loteamento Alphaville Ribeirão Preto e Condomínio Quinta do Golf. (RIBEIRÃO PRETO, 1983).

Em $1^{\circ}$ de julho de 1955, o jornal Diário da Manhã publicou uma nota afirmando que a criação deste parque havia sido aprovada pela Câmara após um ano de espera; dez dias depois, a Lei Ordinária no 425 (RIBEIRÃO PRETO, 1955c) confirma a decisão do legislativo instituindo os mesmos Artigos da supracitada Lei de criação do Parque Infantil do Bosque, exceto em relação as diaristas: em Bonfim, foi prevista a contratação de apenas uma funcionária - o que indica que a estrutura do prédio era menor, em comparação com aquele.

Sobre a denominação do parque, a Lei Ordinária no 2039 determina, em 15 de janeiro de 1968 (RIBEIRÃO PRETO, 1968a), a adoção do nome "Parque Infantil Dra. Iria Junqueira". Segundo Walker e Barbosa (2000) as homenagens realizadas à família Junqueira (Parque do Bosque, Vila Tibério e de Bonfim Paulista) se justificam pela influência que seus membros representaram no setor econômico, político e social da cidade tanto pelas suas atividades ligadas à cafeicultura quanto às benfeitorias realizadas pelas mulheres da família. Para justificar a notoriedade da família no século XX, os autores esclarecem: 
Originalmente criadores de porcos e pecuaristas, tornaram-se cafeicultores e prosperaram. A riqueza lhe deu oportunidade para adquirirem cultura, no sofisticado sentido europeu. Apesar de poucos membros da família terem tido uma educação formal, praticamente todos foram educados na infância por alguns dos melhores tutores particulares que o dinheiro podia comprar. Eles haviam viajado pela Europa e adquirido gostos apurados e maneiras sofisticadas. No rústico e pouco explorado ambiente da antiga Ribeirão Preto, tal cultura e sofisticação naturalmente proporcionaram aos Junqueira grande prestígio e respeitabilidade. (WALKER; BARBOSA, 2000, p. 63).

Não há, nos jornais locais, grandes informações sobre o Parque Infantil Dra. Iria Junqueira. O que se tem é uma reportagem de 16 de outubro de 1966 no Diário da Manhã sobre a Festa de encerramento da Semana da Criança ali realizada, cuja programação havia sido organizada pelo Departamento de Educação e Cultura do município e contava com “preleção, cantos, poesia e gincanas” no parque infantil. (DIÁRIO DA MANHÃ, 1966).

Sobre a quantidade de crianças atendidas neste estabelecimento, o Relatório do Prefeito Costabile Romano de $1957^{43}$ indica uma frequência diária de 60 meninos e meninas.

Por fim, é necessário destacar a existência de dois Decretos voltados para o investimento financeiro da Prefeitura na instituição. Em primeiro lugar, o Decreto $n^{\circ} 123$, de 29 de agosto de 1969 (RIBEIRÃO PRETO, 1969) determina a abertura de crédito no valor de $\mathrm{NCr} \$ 2.000,00$ (dois mil cruzeiros novos) para compra de material de consumo do parque e de outras escolas do Distrito; em segundo lugar, o Decreto $\mathrm{n}^{\circ} 191$ de 7 de setembro de 1975 (RIBEIRÃO PRETO, 1975a) institui um crédito suplementar de Cr\$ 24.550,00 (vinte e quatro mil, quinhentos e cinquenta cruzeiros) para uso exclusivo do parque infantil, na compra de materiais de consumo.

\subsection{7 - Parque Infantil dos Bandeirantes}

Localizado no subsetor N-2 (que abrange, segundo o Decreto $\mathrm{n}^{\circ} 333$ de 26 de dezembro de 1983, os bairros Vila Albertina, Vila Pompéia, Vila Augusta, Vila Pólo, Jardim Javari, Vila Recreio, Vila Abreu Sampaio e Jardim Park Central), este estabelecimento também era conhecido popularmente como "Parque Infantil da Vila Recreio". A legislação referente a esta instituição indica que ele já é criado a partir de normatizações diferentes dos anteriores. Para explicitar esta questão, é necessário analisar dois Decretos e duas Leis Ordinárias publicados no ano de 1963, quando o parque foi inaugurado na Vila Recreio.

\footnotetext{
${ }^{43}$ O documento pode ser encontrado no Arquivo Público e Histórico de Ribeirão Preto, na Pasta 32 - inventário educação.
} 
O Decreto $\mathrm{n}^{\circ} 004$ de 5 de fevereiro foi publicado antes mesmo da inauguração do mesmo e diz respeito sua denominação. Segundo o documento, assinado pelo então prefeito Alfredo Condeixa Filho, a homenagem se justificava pelo fato de que os Bandeirantes foram “desbravadores dos setores brasileiros e pioneiros da civilização do interior”. (RIBEIRÃO PRETO, 1963a).

Em 21 de fevereiro, entretanto, o Decreto nº 010 (RIBEIRÃO PRETO, 1963b) define que nas salas construídas para o referido parque deveria funcionar uma escola municipal chamada de "Professora Conceição Monteiro de Barros". Sobre este Decreto, pairam dois questionamentos que, até o presente momento, estão sem respostas: o primeiro se refere a existência real desta escola (não há, entre os arquivos da prefeitura, nenhuma menção a ela); o segundo diz respeito ao fato de que o Parque dos Bandeirantes possuía salas de aula proposta diferente das observadas em outras instituições parqueanas.

A Lei Ordinária n 1291 de 8 de abril (RIBEIRÃO PRETO, 1963d) cria, oficialmente, a instituição. Abaixo, o conteúdo desta legislação foi reproduzido (em parte) para que se possa cotejar com o conteúdo da Lei de criação do Parque Infantil do Bosque (e, consequentemente, dos Parques que se seguiram até aqui, já que copiaram o mesmo modelo):

Artigo $1^{\circ}$ - Fica, por esta Lei, criado o Parque Infantil de Vila Recreio.

Artigo $2^{\circ}$ - A construção do referido próprio municipal será efetuada em terreno pertencente à Prefeitura.

Artigo $3^{\circ}$ - O Parque Infantil de Vila Recreio terá um corpo docente composto de 6 professôras especializadas.

Paragrafo $1^{\circ}$ - A direção será exercida por professores municipal, escolhida dentre as nomeadas para o Parque, mediante a gratificação mensal estabelecida na tabela de que trata a Lei $n^{\circ} 1004$, de 23 de fevereiro de 1961. Paragrafo $2^{\circ}$ - Poderá a Prefeitura Municipal, para o bom desempenho das finalidades do Parques Infantil, aceitar a colaboração de professores estaduais especializados, sem ônus para o Município, exceto quando exercendo a função de direção.

Artigo $4^{\circ}$ - Além dos professores acima referidos, contará o Parque Infantil de Vila Recreio com mais 6 funcionários, sendo 3 do sexo masculino e 3 do sexo feminino, para os serviços diversos. (RIBEIRÃO PRETO, 1963d).

A partir desta Lei, nota-se que a organização do Parque dos Bandeirantes se diferenciava dos demais não apenas em relação à ausência de menção sobre o serviço de assistência médico-escolar, mas, também, por não contar com nenhum tipo de orientação do DEF-SP. A inauguração ocorreu em 11 de maio de 1963 e, segundo o jornal Diário da Manhã, contou com uma missa celebrada pelo Arcebispo metropolitano Dom Agnelo Rossi e com a presença de autoridades municipais e da população em geral (figura 13). 
Figura 13 - Dom Agnelo Rossi descerrando a fita de inauguração do Parque Infantil dos Bandeirantes ao lado

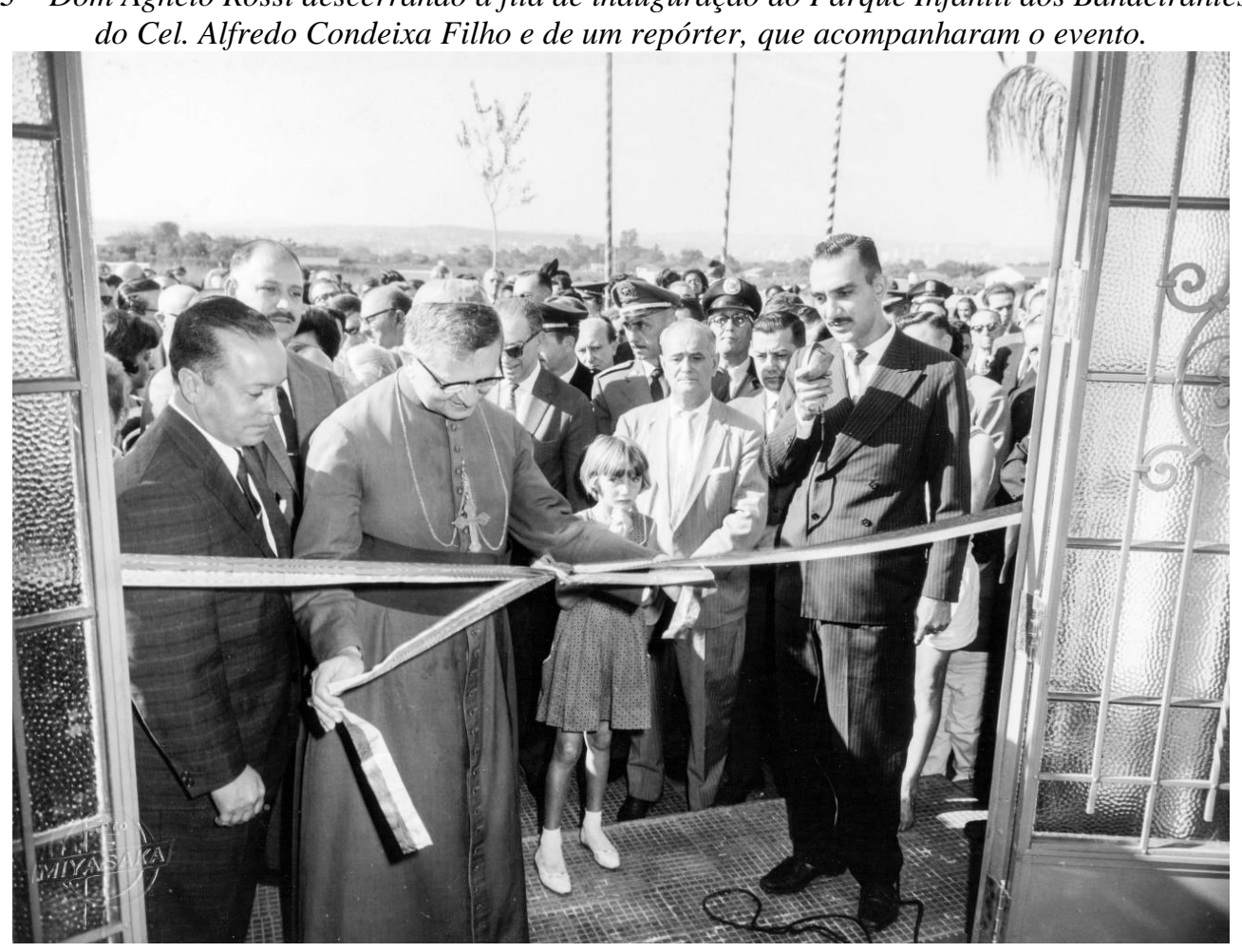

Fonte: Arquivo Público e Histórico de Ribeirão Preto ${ }^{44}$

Em 30 de dezembro do mesmo ano, a Lei Ordinária no 1389 determinou a criação de cargos de duas professoras e oito serventes para o Parque dos Bandeirantes - número bem maior do que aquele registrado em outras instituições parqueanas municipais. O que justificaria esse aumento nas contratações seria um aumento na quantidade de crianças atendidas, mas, segundo um Ofício de 12 de março de 1965, o parque tinha frequência diária de aproximadamente 250 crianças - número inferior do que os registrados em outras instituições já analisadas.

\subsection{8 - Parque Infantil de Santa Cruz do Jacques}

Diferentemente do Parque dos Bandeirantes, este conta, em sua Lei de criação $\mathrm{n}^{\circ}$ 1274, de 27 de dezembro de 1962 (RIBEIRÃO PRETO, 1974a), com o Serviço médico dentário organizado pelo Departamento Municipal de Saúde para as crianças frequentadoras.

A inauguração do parque infantil do bairro Santa Cruz do Jacques só ocorreu, entretanto, em 25 de julho de 1965, de acordo com o jornal Diário da Manhã. Chama atenção

\footnotetext{
${ }^{44}$ O documento pode ser encontrado no Arquivo Público e Histórico de Ribeirão Preto, no fundo Cel. Alfredo Condeixa Filho, na Pasta 88, $n^{\circ}$ de registro 1102.
} 
o fato de que nesta notícia, a instituição seja chamada de "Parque Infantil Ana dos Santos Gabarra”, mesmo que não haja nenhuma Lei que defina essa denominação.

Em 5 de outubro do mesmo ano, uma nota publicada pelo mesmo jornal expressa que o atendimento médico-odontológico aos parqueanos já se encontrava em pleno funcionamento naquela data, o que confirma o conteúdo da Lei de criação citada anteriormente. Outras informações a respeito do funcionamento deste parque não foram localizadas no Arquivo Público Municipal.

É importante considerar, ainda, que a região onde o parque infantil foi instalado corresponde atualmente ao subsetor S-3, onde também ficam os bairros Jardim Irajá, Jardim Itamarati, Vila Matilde e Condomínio Village São Francisco. (RIBEIRÃO PRETO, 1983). Nesta localidade está em funcionamento a Escola Municipal de Educação Infantil Ana dos Santos Gabarra.

\subsection{9 - Parque Infantil da Lapa}

Em 4 de março de 1967, o jornal Diário da Manhã anuncia que "graças a um intenso trabalho liderado pelo Dr. Alpheu Gasparini, Diretor do Departamento de Educação e Cultura da Municipalidade", ocorrerá o lançamento do parque infantil no bairro da Lapa. Pouco mais de dois meses depois, em 27 de maio de 1967, o jornal trata de um plano de expansão das instituições educacionais da cidade e da atenção que o prefeito Welson Gasparini registrava no âmbito da Educação, considerando que o novo parque atenderia 350 crianças "do próprio bairro, bem como aquelas que residem nas imediações", com o objetivo de promover educação, oferecer um tipo moderno de recreação infantil e cuidar da assistência médica e odontológica dos frequentadores.

No que se refere aos aspectos legais da implantação, destaca-se a Lei Ordinária $\mathrm{n}^{\circ}$ 1282, de 21 de fevereiro de 1963, que autoriza a construção do parque (RIBEIRÃO PRETO, 1963c); o Decreto $n^{\circ}$ 067, que determina a utilidade pública do terreno destinado à instituição e define sua localização (RIBEIRÃO PRETO, 1965) ${ }^{45}$; e, por fim, o Decreto $\mathrm{n}^{\text {o }} 147$, que define o nome "Parque Infantil Padre Emílio Jarbinet", em homenagem a um vigário do bairro (RIBEIRÃO PRETO, 1968b).

O subsetor da instituição é o N-1, onde se encontram os Campos Elíseos, o Jardim Mosteiro, a Vila Lapa, a Vila Coronel Quito Junqueira, a Vila Tamandaré, a Vila América, a Vila Gertrudes, o Parque São José e a Vila Zanetti. (RIBEIRÃO PRETO, 1983). 


\subsubsection{0 - Parque Infantil da Vila Lobato}

A "Vila Lobato" estava localizada, nos anos de 1970, na região que hoje é representada pelo subsetor O-5 (Vila Monte Alegre, Jardim Antarctica, Jardim Santa Luzia e parte Vila Manoel Junqueira), discriminado pelo Decreto $\mathrm{n}^{\circ} 333$, de 26 de dezembro de 1983. (RIBEIRÃO PRETO, 1983).

Não foi possível identificar nenhuma publicação em jornais locais sobre o bairro e sobre o parque infantil. O que se tem, entretanto, é o conteúdo da Lei de criação, dois Decretos que tratam desta instituição e um documento encontrado no Fundo "Escolas" da Secretaria Municipal de Planejamento - onde consta que a fundação do parque ocorreu em 7 de abril de 1970.

O Decreto $n^{\circ} 168$ (RIBEIRÃO PRETO, 1972) regulariza a ampliação da área destinada ao parque, definindo a utilidade pública do terreno vizinho. Publicado em 12 de setembro de 1972, o documento apresenta, também, as características do local:

O terreno de forma irregular [...] com frente para a rua João Alves Pereira, lado ímpar da numeração desta rua, com a seguinte dimensão e confrontação: frente para a rua João Alves Pereira, com 17,28 metros; do lado direito de quem desta rua olha para o imóvel, com 33,35 metros e confronta-se com terrenos de João Batista Said; do lado esquerdo com 34,50 metros e confronta-se com o Parque Infantil de Vila Lobato e nos fundos com 25,60 metros, confrontando-se com os prédios de n ${ }^{\circ}$ s. 288, 294 e 298 da rua Severino Joaquim Bruno, com a área total de 714,52 metros quadrados, de propriedade de João Batista Said ou sucessores. (RIBEIRÃO PRETO, 1972).

Em 1973, a Lei 2756 oficializa sua criação, "sob o mesmo regime dos congêneres municipais". (RIBEIRÃO PRETO, 1973a).

O nome do Parque, por sua vez, é definido pelo Decreto no 376 (RIBEIRÃO PRETO, 1975b), que institui a denominação "Professora Áurea Apparecida Braghetto Machado".

\subsubsection{1 - Parque Infantil de Guatapará II}

Em 27 de junho de 1974, o prefeito Welson Gasparini assina a Lei Ordinária no 2903 (RIBEIRÃO PRETO, 1974b), estipulando um crédito de Cr\$200.000,00, para construção de um parque infantil no distrito de Guatapará. Segundo um documento encontrado no Fundo

\footnotetext{
${ }^{45}$ Entre as Ruas Coelho Neto e Vicente Golfeto, com a área de 2.973,60 m². (RIBEIRÃO PRETO, 1965).
} 
Educação da Secretaria Municipal do Planejamento, o referido parque foi instalado em 21 de outubro de 1975.

Após cinco anos, a Lei no 3839 de 24 de outubro de 1980 (RIBEIRÃO PRETO, 1980a), alterou o nome da instituição para "Escola Básica de $1^{\circ}$ Grau Euclides Castilhano".

\subsubsection{2 - Parque Infantil José Pedro Moreira}

Localizado no bairro Vila Fraternidade, o parque infantil foi criado a partir da Lei Ordinária 3334, de 12 de julho de 1977 (RIBEIRÃO PRETO, 1977a). As dificuldades em relação à investigação sobre este Parque são justificadas pelo fato de a Lei não estar disponível para acesso público e, além disso, pelo fato de que não há notícias em jornais locais sobre o Parque.

O principal indício de que a instituição de fato foi implantada, é a existência de uma Escola Municipal de Educação Infantil com o mesmo nome, no próprio bairro da Vila da Fraternidade, atualmente chamado de Parque Ribeirão Preto (subsetor O-8, segundo o Decreto $\mathrm{n}^{\circ} 333$, de 26 de dezembro de 1983).

\subsubsection{3 - Parque Infantil da Vila Albertina}

A Lei Ordinária no 3618, de 17 de maio de 1979 (RIBEIRÃO PRETO, 1979), foi a responsável pela sua criação e determinou que a implantação ocorresse na esquina da Rua Espírito Santo com a Rua Rio Maroni (subsetor N-2). Atualmente, o endereço corresponde a uma praça onde estão instalados equipamentos de um parque de diversões.

\subsubsection{4 - Parque Infantil dos Campos Elíseos}

Em 7 de outubro de 1958, o jornal Diário da Manhã já defendia a construção de um parque infantil no bairro dos Campos Elíseos, afirmando que esta obra representaria uma atração especial para o bairro. Quatro anos mais tarde, em 8 de junho, o jornal publica em uma edição especial, uma página inteira a respeito dos Campos Elíseos, o que indica a importância do bairro para o município:

Contando com vida própria, pouco dependendo do resto da cidade, com comércio e indústria pujante, atividades culturais intensas, atividades esportivas, sociais, de classe, assistenciais, se desenvolvendo em grande 
escola, o progresso do bairro é impressionante. [...] Em compensação, multiplicam-se os problemas, todos eles oriundos do grande progresso, necessitando por isto mesmo, a administração municipal dedicar um carinho todo especial para com os Campos Eliseos. (DIÁRIO DA MANHÃ, 1962).

Considerando, ainda, que este era o bairro mais populoso da cidade, uma instituição de atendimento à criança seria fundamental para as famílias ali residentes.

Apesar de não haver, dados concretos acerca da instalação do parque, a informação presente na website ${ }^{46}$ da prefeitura afirma que este funcionou no interior de uma Escola de Ensino Fundamental do bairro (EMEF Dom Luiz do Amaral Mousinho, existente até hoje). Sobre este fato, cumpre destacar que o Parque, supostamente, não apresentava as mesmas características daqueles que foram construídos anteriormente na cidade.

\subsubsection{5 - Parques Infantis da Vila Paulista, da Vila Abranches e da Vila Seixas}

Estes três parques infantis, apesar de terem suas Leis de criação publicadas no Diário Oficial do Município, não possuem indícios de terem sido instalados de fato na cidade. Abaixo, segue quadro 3 com as Leis de cada um:

Quadro 3 - Leis de criação dos parques que não têm implantação comprovada

\begin{tabular}{|c|c|}
\hline Localização do Parque Infantil & Lei de Criação \\
\hline Vila Paulista (subsetor L- $2^{47}$ ) & $\begin{array}{l}\mathrm{n}^{\circ} 890, \text { de } 31 \text { de } \text { dezembro de } 1959 \\
\text { (RIBEIRÃO PRETO, 1959c) }\end{array}$ \\
\hline Vila Abranches (subsetor L-10 ${ }^{48}$ ) & $\begin{array}{l}\mathrm{n}^{\mathrm{o}} 1475, \text { de } 10 \text { de novembro de } 1964 \\
\text { (RIBEIRÃO PRETO, 1964a) }\end{array}$ \\
\hline Vila Seixas (subsetor L-1 ${ }^{49}$ ) & $\begin{array}{l}\mathrm{n}^{\circ} \quad 1507, \text { de } 1^{\circ} \text { de } \text { dezembro de } \\
\text { 1964(RIBEIRÃO PRETO, 1964b) }\end{array}$ \\
\hline
\end{tabular}

Fonte: produção do próprio autor

Sobre o Parque Infantil de Vila Paulista, é necessário considerar que a Lei no 1276, de 27 de dezembro de 1962 (RIBEIRÃO PRETO, 1962b) autorizou o crédito de cr\$ 5.000.000 para a construção do mesmo e que dois jornais municipais publicaram notas a respeito da

\footnotetext{
${ }^{46}$ PREFEITURA MUNICIPAL DE RIBEIRÃO PRETO. EMEI Professora Carmem Massarotto. Disponível em: <https://www.ribeiraopreto.sp.gov.br/seducacao/escolas/masaroto/i15masaroto.php>. Acesso em: 20 maio 2015.

${ }^{47} \mathrm{O}$ mesmo subsetor do Parque Infantil do Bosque.

${ }^{48}$ Onde se localizam o atual Parque São Sebastião, o Jardim do Trevo, o Jardim Interlagos, o Jardim José Figueira e o Loteamento Cândido Portinari. (RIBEIRÃO PRETO, 1983).

49 Onde também estão os bairros Higienópolis e Jardim América. (RIBEIRÃO PRETO, 1983).
} 
obra. O jornal Diário de Notícia em 10 de abril informou: "Prefeito apresenta Projeto de Lei do Parque de Vila Paulista”. (DIÁRIO DE NOTÍCIA, 1959); e o jornal A Cidade de 21 de novembro: "Vila Paulista terá seu Parque Infantil". (A CIDADE, 1959).

Em 6 de março de 1965, o jornal Diário da Manhã anunciou em nota que o projeto de Lei sobre a criação do parque na Vila Abranches foi apresentado pelo vereador José Bompani, naquela data.

\subsubsection{6 - Parque Infantil de Dumont}

Em 1957, o Relatório do Prefeito Costabile Romano ${ }^{50}$ indicou que, no Distrito de Dumont, havia sido construído um "belíssimo Recanto Infantil, com todas as instalações necessárias, que a exemplo dos existentes nos outros Distritos, vem prestando ótima assistência às crianças".

Em 12 de março de 1965, um ofício encontrado no Inventário Educação do Arquivo Municipal $^{51}$ indica que neste parque, a frequência girava em torno de 80 crianças.

É importante considerar que Dumont foi Distrito de Ribeirão Preto até 28 de fevereiro de 1964, quando a Lei estadual no 8092 (SÃO PAULO, 1964) desmembrou as cidades.

\footnotetext{
${ }^{50} \mathrm{O}$ documento pode ser encontrado no Arquivo Público e Histórico de Ribeirão Preto.

${ }^{51}$ Ibidem, na Pasta 32 - inventário educação.
} 


\section{CONSIDERAÇÕES FINAIS}

O que se observa ao longo do presente trabalho é que os parques infantis municipais, do ponto de vista dos jornais locais do período, consistiam como instalações essenciais para a infância e para a sociedade ribeirão-pretana. Isto porque, em relação às crianças, ofereciam recreação e assistência e, em relação aos adultos, ofereciam condições para que estivessem envolvidos no mundo do trabalho e, consequentemente, colaborassem para o desenvolvimento industrial da cidade.

O outro lado da moeda, entretanto, revela uma realidade cruel: que regime de trabalho era esse ao qual se submetiam os operários, que não tinham possibilidade de oferecer nem mesmo a alimentação dos próprios filhos? Que organização social foi essa que buscou nos parques infantis a solução para a vida miserável de suas crianças e para a aceitação das más condições de trabalho e moradia pelos seus pais?

Enquanto os gestores municipais se glorificavam pela "ação social" que promoviam com a implantação das instituições, as famílias, cada vez mais, compreendiam o atendimento a criança como uma benfeitoria, uma caridade. Em outras palavras, vê-se que a pobreza deu origem à filantropia, e não à mobilização de políticas. Deste ponto de vista, a existência dos parques infantis, adiou a concepção do Direito na educação pré-escolar de Ribeirão Preto.

Sobre a questão da Educação, outro ponto chamou atenção durante o desenvolvimento da pesquisa com os jornais: através das notícias publicadas, nota-se que no início dos anos 50, quando o projeto passou a ser concretizado no município, a abordagem que se fazia sobre o seu funcionamento e seu valor social se baseava no aspecto recreativo e ignoravam o caráter educacional e assistencial - este último, lembrado nos ofícios que o DEF-SP encaminhou para a Prefeitura neste período. Já em 1956, o Álbum do $1^{\circ}$ Centenário (SOUZA, 1956) destaca em um de seus artigos escritos por uma especialista em Educação tanto a importância da recreação oferecida nos parques para o desenvolvimento físico e mental das crianças, quanto a assistência odonto-médica-alimentar, considerada como uma vantagem de tal instituição. Neste mesmo Álbum, consta que o enriquecimento do intelecto deve ficar à cargo dos Grupos Escolares - como se a rotina no espaço dos parques não representasse o desenvolvimento intelectual das crianças que ali interagiam. Tudo isso nos faz considerar que apesar de a implantação ter ocorrido e, aparentemente, ter sido de grande valor para a população, as concepções sobre o conceito de Parque Infantil ainda não estavam consolidadas nem pelos 
usuários, nem pelos gestores municipais, nem pela mídia e nem, ao menos, para os educadores.

Ao que parece, na tentativa de "controlar" a parcela pobre da sociedade, a instituição surgiu para bem tratar suas crianças. Fornecer agasalhos e brinquedos não era uma tarefa difícil; a prefeitura se vangloriava, de fato, era com a boa dentição e saúde das camadas populares - atendimento esse que foi facilitado, provavelmente, pela existência da Faculdade de Medicina e Odontologia na cidade.

Distante do projeto criado por Mário de Andrade em São Paulo, o modelo implantado em Ribeirão Preto não possuía, segundo os documentos do Arquivo Municipal, nenhum vínculo ou inspiração no folclore brasileiro. A preocupação com a apropriação e produção de cultura por parte das crianças também não foi observada nas ações desenvolvidas nos parques municipais, cujo principal destaque se dava no âmbito dos campeonatos de futebol. Esta simplificação dos objetivos da instituição pode ter reduzido seus custos perante a prefeitura municipal. Se a inviabilidade do custo fez com que os parques da capital perdessem suas características iniciais, em Ribeirão Preto eles já foram implantados a partir de um modelo de baixo custo - esta é a hipótese para que o fato de que a instituição tenha sido implantada na cidade num período em que já não se investia nos parques pioneiros de São Paulo.

Tomando cuidado para não entrar na armadilha da idealização do passado em detrimento da Educação no presente, a realização da presente pesquisa se relaciona ao desejo de que a educação pré-escolar seja melhor compreendida tanto no âmbito das políticas públicas que a sustentam, quanto em termos de práticas pedagógicas adotadas no interior das instituições.

Reconhecer que a importância das instituições de atendimento pré-escolar não está vinculada à preparação para a alfabetização e para o estímulo desenfreado das linguagens e habilidades das crianças, como tanto se fala; a existência de instituições pré-escolares deve estar relacionada, sim, às experiências de interação e socialização - considerando sempre que são elas que se interpõem entre o domínio familiar e o conhecimento de mundo por parte da criança. Colocar, portanto, a cultura como eixo do trabalho, desenvolver atividades lúdicas, promover a brincadeira, os jogos, o desenvolvimento artístico e o movimento dos corpos é papel da educação infantil, etapa de fundamental importância para a formação dos adultos do futuro.

Além de desejar que o presente trabalho provoque um impacto nas reflexões sobre educação pré-escolar, pretende-se que a realização de tal investigação mobilize estudantes, educadores, historiadores e sociedade em geral em prol da memória da cidade de Ribeirão 
Preto. Infelizmente, instituições como o Arquivo Público Municipal, Museu do Café, Museu da Imagem e do Som e Bibliotecas Municipais têm sido esquecidas pelo poder público da cidade. Reconhecer o valor destes acervos é colaborar para a preservação da história da cidade.

Portanto, cumpre reforçar a defesa por uma educação pública gratuita e de qualidade, como lutava o intelectual Mário de Andrade, tanto na educação infantil como nos anos que se seguem. Enquanto professora da rede municipal de ensino, observo que a cidade vive um momento de efervescência, onde as famílias passam a reconhecer a escola como espaço de construção coletiva e os professores passam a se mobilizar em torno de condições de trabalho cada vez melhores. É preciso que a Secretaria da Educação fortaleça este movimento e trabalhe no desenvolvimento de propostas cada vez mais coerentes para a formação do cidadão ribeirão-pretano que sonhamos.

Por isso, a realização da presente pesquisa se relaciona ao desejo de que a educação pré-escolar seja melhor compreendida tanto no âmbito das políticas públicas que a sustentam, quanto em termos de práticas pedagógicas adotadas no interior das instituições. 


\section{REFERÊNCIAS}

A CIDADE. Ribeirão Preto. São Paulo, 1950-1959.

A TARDE. Ribeirão Preto. São Paulo, 1948-1967.

ABDANUR, Elizabeth França. Os "ilustrados" e a política cultural em São Paulo: o Departamento de Cultura na gestão Mário de Andrade (1935-1938). 1992. Dissertação (Mestrado em História)-Instituto de Filosofia e Ciências Humanas, Universidade Estadual de Campinas, Campinas, 1992.

Parques Infantis de Mário de Andrade. Revista do Instituto de

Estudos Brasileiros, São Paulo, n. 36, p. 263-270, 1994.

AGUIAR, Augusta (Org.). Álbum histórico e fotográfico dos postos odontológicos do serviço dentário municipal de Ribeirão Preto. Ribeirão Preto, 1963.

AMERICANA. Decreto $n^{\circ} 443$, de 1969. Regulamenta a idade da matrícula das crianças no parque infantil municipal, 1969.

parque infantil, 1973.

Decreto $n^{\circ} 647$, de 10 de dezembro de 1973. Define as finalidades do

ANCONA LOPEZ, Telê. Mário de Andrade: táxi e crônicas no Diário Nacional. São Paulo: Duas Cidades, 1976.

ANDRADE, Mário de. Dia de São Paulo. RAM. São Paulo, v. 18, p. 271-4, 1935.

Aspectos da literatura brasileira. São Paulo: Martins, 1974.

Cartas. Oneyda Alvarenga. São Paulo: Duas cidades, 1983.

Janeiro: José Olympio, 1982.

Lição do amigo: cartas a Carlos Drummond de Andrade. Rio de

ARQUIVO PÚBLICO E HISTÓRICO DE RIBEIRÃO PRETO. Estrutura. Disponível em: $<$ https://www.ribeiraopreto.sp.gov.br/scultura/arqpublico/i14index.php?pagina=/scultura/arqp ublico/estrutura/i14estrutura.htm>. Acesso em: 20 mar. 2015.

ARQUIVO PÚBLICO E HISTÓRICO DE RIBEIRÃO PRETO. História de Ribeirão Preto. Disponível em: <http://www.arquivopublico.ribeiraopreto.sp.gov.br/scultura/arqpublico/i14in dex.php?pagina=/scultura/arqpublico/historia/i14indice.htm>. Acesso em: 20 mar. 2015.

AZEVEDO, Fernando de. Da Educação Física: o que ela é, o que tem sido e o que deveria ser. 3. ed. São Paulo: Melhoramentos, 1960.

BLOCH, Marc. Apologia para la historia o el ofício de historiador. México: FCE, 2001.

BOMENY, Helena. Os intelectuais da educação. Rio de Janeiro: Jorge Zahar, 2003. 
BORGES, Maria Eliza Linhares. História \& Fotografia. Belo Horizonte: Autêntica, 2003.

BOSI, Alfredo. Cultura como tradição. In: BORNHEIM , G.; BOSI , A.; P ESSANHA, J. A. M. (Orgs.). Cultura brasileira: tradição/contradição. Rio de Janeiro: Jorge Zahar, 1987. p. $31-58$.

BRASIL. Constituição. (1937) Constituição dos Estados Unidos do Brasil. Rio de Janeiro, 1937.

Decreto $n^{\circ} 16.300$, de 1923. Institui o Departamento Nacional de Saúde Pública e a Inspetoria de Higiene Infantil, 1923.

Decreto ${ }^{\circ} 19.890$, de 18 de abril de 1931. (Reforma Francisco

Campos). Organização do Ensino Secundário. Ministério da Educação e Saúde Pública, Rio de Janeiro, Imprensa Nacional, 1931.

Decreto $n^{\circ} 6583$, de $1^{\circ}$ de agosto de 1934. Regulamenta o

Departamento de Educação Física do Estado de São Paulo, 1934.

Decreto nº 2072, de 8 de março de 1940. (Educação Moral e Cívica)

Organização do Ensino Secundário. Ministério da Educação e Saúde Pública, Rio de Janeiro, Imprensa Nacional, 1940.

. Projeto de Lei ${ }^{\circ} 786$, de 7 de maio de 1959. Dispõe sobre a criação do serviço de recreação. Diário Oficial do Estado de São Paulo, 7 maio 1959. Ano LXIX, n. 100, p. 64.

CAMPOS, Maria Malta et al. Diagnóstico da situação da educação pré-escolar na região metropolitana de São Paulo. Fundação Carlos Chagas, 1988.

CAMPOS, Raquel Discini de. No rastro de velhos jornais: considerações sobre a utilização da imprensa não pedagógica como fonte para a escrita da história da educação. Rev. Bras. Hist. educ., Campinas, v. 12, n. 1 (28), p. 45-70, jan/abr. 2012.

CARPINTEIRO, Marisa Varanda. O Urbanismo no Instituto de Engenharia: São Paulo, 19201940. In: RIBEIRO, L. C. de Queiroz; PECHMAN, Robert. (Orgs.). Cidade, Povo e Nação.

Gênese do Urbanismo Moderno. Rio de Janeiro: Civilização Brasileira, 1996.

CASTELLANI FILHO, Lino. Educação Física no Brasil: a história que não se conta. 19. ed. Campinas: Papirus, 2013.

CAVALIERE, Ana Maria. Entre o pioneirismo e o impasse: a reforma paulista de 1920.

Educação e Pesquisa, Brasil, v. 29, n. 1, p. 27-44, jun. 2003.

CERTEAU, Michel. A Escrita da História. Rio de Janeiro: Forense Universitária, 2007.

CIONE, Rubem. História de Ribeirão Preto. Ribeirão Preto: Editora Legis Summa, v. 5, 1997. 
CORREIO PAULISTANO. Ribeirão Preto. São Paulo, 1939.

CUNHA, Marcus Vinicius da. A educação dos Educadores: da Escola Nova à escola de hoje. Campinas: Mercado das Letras, 1995.

DALBEN, André. Educação do corpo e vida ao ar livre: natureza e educação física em São Paulo (1930 - 1945). 2009. Dissertação (Mestrado em Educação Física)-Faculdade de Educação Física, Universidade Estadual de Campinas, Campinas, 2009.

O esporte nas colônias de férias escolares do Estado de São Paulo

(1940 - 1950). In: XIV ENCONTRO REGIONAL DE HISTÓRIA DA ANPUH-RJ, 2010, Rio de Janeiro. Anais... Rio de Janeiro: NUMEN, 2010.

DARAHEM, Gabriela Campos. Contribuição para a história da educação infantil em Ribeirão Preto: experiências de funcionários e professoras das Escolas Municipais de Educação infantil (EMEIs). 2011. Dissertação (Mestrado em Psicologia)-Faculdade de Filosofia, Ciências e Letras de Ribeirão Preto, Universidade de São Paulo, Ribeirão Preto, 2011.

DASSIM, Joan. Política e poesia em Mário de Andrade. São Paulo: Duas Cidades, 1978.

DEPARTAMENTO DE EDUCAÇÃO FÍSICA DE SÃO PAULO. Relatório de atividades de 1942. 1942.

DEPARTAMENTO DE EDUCAÇÃO FÍSICA DE SÃO PAULO. Parque infantil. 1950.

DIÁRIO DA MANHÃ. Ribeirão Preto, São Paulo, 1948-1967.

DIÁRIO DE NOTÍCIAS. Ribeirão Preto, São Paulo, 1948-1951.

DUARTE, Paulo. Mário de Andrade por ele mesmo. 2. ed. São Paulo: Hucitec, 1985.

ESPÍRITO SANTO, Silvia Maria do. Traços de um colecionador público em Ribeirão

Preto. 2010. Disponível em: <www.revistamuseu.com.br/artigos/art_.asp?id=23639>. Acesso em: 10 dez. 2014.

FARIA, Ana Lúcia G. A contribuição dos parques infantis de Mário de Andrade para a construção de uma pedagogia da educação infantil. Educação \& Sociedade, Campinas, v. 20, n. 69, p. 60-91, 1999a.

Educação pré-escolar e cultura. Campinas: Unicamp, 1999b.

FERREIRA, Débora Menengotti. Memórias do magistério: idealização do passado e exercício da profissão no presente. Ribeirão Preto, 2010. 62 f. Iniciação Científica (Programa Ensinar com Pesquisa)-Faculdade de Filosofia, Ciências e Letras de Ribeirão Preto, Universidade de São Paulo, 2010.

FGV CPDOC. Armando Sales. Disponível em: <cpdoc.fgv.br/producao/dossies/Aera Vargas1/biografias/armando_sales>. Acesso em: 28 maio 2015. 
FINCOTI, Michele Cristina. Memórias do magistério: idealização do passado e exercício da profissão no presente. 2012. 89 f. Iniciação Científica (Programa Ensinar com Pesquisa)Faculdade de Filosofia, Ciências e Letras de Ribeirão Preto, Universidade de São Paulo, 2012.

FONSECA, João Pedro. O cinquentenário dos parques infantis de São Paulo: 1935-1985. Revista da Faculdade de Educação, São Paulo, v. 11, n. 1-2, p. 135-148, jan/dez. 1985.

FONSECA, Cristina M. Oliveira. Práticas sanitárias ou práticas pedagógicas? A institucionalização das atividades de educação em saúde no $1^{\circ}$ governo Vargas (1930-45). In: MAGALDI, Ana Maria; ALVES, Cláudia; GONDRA, José G. (Orgs.). Educação no Brasil: história, cultura e política. Bragança Paulista, EDUSP, 2003.

FONSECA, Thais N. de L; VEIGA, Cynthia G. História e Historiografia da Educação no Brasil. Belo Horizonte: Autêntica, 2003.

GHIRALDELLI JÚNIOR, Paulo. Educação Física Progressista: A Pedagogia Crítico-Social dos Conteúdos e a Educação Brasileira. 10. ed. São Paulo: Loyola: 2003.

GOMES, Ana Carolina Vimieiro; DALBEN, André. O controle médico-esportivo no Departamento de Educação Física do Estado de São Paulo: aproximações entre esporte e medicina nas décadas de 1930 e 1940. História, Ciências, Saúde - Manguinhos, Rio de Janeiro, v. 18, n. 2, p. 321-335. abr.-jun. 2011.

GUIMARÃES, Edvania. Um breve histórico sobre a educação infantil na cidade de Americana. 1999. Monografia (Trabalho de conclusão de curso de Pedagogia)-Faculdade de Educação, Universidade Estadual de Campinas, Campinas, 1999.

HERSCHMANN, Micael M.; PEREIRA, Carlos Alberto Messeder (Org.) A invenção do Brasil moderno: medicina, educação e engenharia nos anos 20-30. Rio de Janeiro: Rocco, 1994.

KISHIMOTO, Tizuko Morchida. A pré-escola em São Paulo (1877 a 1940). São Paulo: Edições Loyola, 1988.

Fröebel e a concepção de jogo infantil. In: KISHIMOTO, T. M. O brincar e suas teorias. São Paulo: Pioneira, 2002.

KOSSOY, Boris. Os tempos da fotografia. Cotia: Ateliê Editorial, 2007.

KUHLMANN JR., Moysés. A educação infantil no século XX. In: STEPHANOU, Maria; BASTOS, Maria Helena Câmara (Orgs.). Histórias e memórias da educação no Brasil. Rio de Janeiro: Vozes, 2005.

Educando a infância brasileira. In: LOPES, E.M.T, FARIA FILHO, L.M., VEIGA, C.G. 500 anos de Educação no Brasil. Belo Horizonte: Autêntica, 2000, p. 469-496.

Mediação: 2010.

Infância e educação infantil: uma abordagem histórica. Porto Alegre: 
; RAMOS, Maria Martha Silvestre. Políticas e organização do Parque

Infantil no município de Campinas. 2001. Disponível em:

<http://24reuniao.anped.org.br/T0711731363413.doc>. Acesso em: 15 jan. 2015.

LASTÓRIA, Andrea Coelho. (Org.). Atlas Escolar Histórico, Geográfico e Ambiental de Ribeirão Preto. 1. ed. Ribeirão Preto: 2008. v. 1. 140 p. Disponível em:

$<$ http://falagrupoelo.blogspot.com.br/p/atlas-escolar-municipal.html>. Acesso em: 27 set. 2014.

LE GOFF, J. Documento/Monumento. In: Enciclopédia Einaudi. Lisboa: Imprensa Nacional/Casa da Moeda, v. 1, 1984.

LOPES, Eliane Marta Teixeira; GALVÃO, Ana Maria de Oliveira. História da Educação. Rio de Janeiro: DP\&A, 2001.

LOURENÇO FILHO, Manuel Bergström. A questão dos programas. Escola Nova, São Paulo, v. 1, n. 2/3, p. 86-95, nov/dez, 1930.

LOURO, Guacira L. Mulheres na sala de aula. In: PRIORE, Mary del (Org). História das mulheres no Brasil. São Paulo: Contexto, 1997.

MANACORDA, Mario Alighiero. História da Educação: da Antiguidade aos nossos dias. São Paulo: Cortez, 1989.

MARROU, Henri-Irénée. Sobre o conhecimento histórico. Rio de Janeiro: Zahar Editores, 1978.

MASSUCATO, José Geraldo; BARBANTI, Valdir José. Histórico da Escola de Educação Física e Esporte da Universidade de São Paulo. Revista Paulista de Educação Física. v. 13, p. 7-12, dez. 1999.

MASTROROSA, Adriano. Departamento de Educação Física, Escola Superior de Educação Física e Associação dos Professores de Educação Física: o ordenamento da Educação Física no Estado de São Paulo no início da década de 1930.2003. Dissertação (Mestrado)-Faculdade de Educação, PUC, São Paulo, 2003.

MATE, Cecilia Hanna. Tempos modernos na escola: os anos 30 e a racionalização da educação brasileira. Bauru: EDUSC; Brasília: INEP, 2002.

MICARONI, Silvana. A educação física nos parques infantis da cidade de São Paulo: 1947 a 1957. 2007. Dissertação (Mestrado em Educação)-Universidade São Francisco, Itatiba, 2007.

MIRANDA, Nicanor. Origem e propagação dos parques infantis e parques de jogos. Departamento de Cultura, São Paulo, 1941. Plano inicial da Seção de Parques Infantis. Revista Arquivo Municipal, São Paulo, n. 20, p. 95-98, 1936. 
NIEMEYER, Carlos Augusto. A criação de espaços públicos de lazer organizado como expressão de cidadania: o caso dos parques infantis de São Paulo (1934-1954). 2001. Dissertação (Mestrado em Estruturas Ambientais Urbanas)-Faculdade de Arquitetura e Urbanismo da Universidade de São Paulo, São Paulo, 2001.

OLIVEIRA, Waldemar de. Os parques de recreação em São Paulo. Revista do Arquivo Municipal, v. XXXV, p. 272-274, mai. 1937.

OLIVEIRA, Zilma de Moraes et al. Creches: crianças, faz de conta \& cia. Petrópolis: Vozes, 1992.

OLIVEIRA, Suad A. R. de. A história do primeiro parque infantil municipal de Sorocaba: o contexto histórico e as circunstâncias específicas da criação e da instalação da escola.

Conjectura, v. 15, n. 3, set/dez. 2010.

PAULILO, André Luiz. As estratégias de administração das políticas públicas de educação na cidade do Rio de Janeiro entre 1922 e 1935. Rev. Bras. Educ., Rio de Janeiro, v. 14, n. 42, p. 440-455, dez. 2009.

PEREIRA, Mônica. O Parque Infantil "Leonor Mendes de Barros" da cidade de Araraquara (1941-1971). 2008. Monografia (Licenciatura em Pedagogia)-Universidade Federal de São Carlos, São Carlos, 2008.

PIMENTA, Jussara Santos. As duas margens do Atlântico: um projeto de integração entre dois povos na viagem de Cecília Meireles a Portugal (1934). 2008. Tese (Doutorado em Educação)-Universidade do Estado do Rio de Janeiro, Rio de Janeiro, 2008.

PIRES, Julio Manuel. O desenvolvimento econômico de Ribeirão Preto: 1930-2000. In: Associação comercial e industrial de ribeirão preto. (Org.). Um espelho de 100 anos: Associação Comercial e Industrial de Ribeirão Preto 1904-2004. 1. ed. Ribeirão Preto: ACI, 2004. p. 179-192.

PRANDI, Maria Beatriz Ribeiro. A construção da imagem dos parques infantis de Ribeirão Preto das décadas de 1950 e 1960. 2015. 168 f. Dissertação (Mestrado em Educação)-Faculdade de Filosofia, Ciências e Letras de Ribeirão Preto, Universidade de São Paulo, Ribeirão Preto, 2015.

PREFEITURA MUNICIPAL DE RIBEIRÃO PRETO. EMEI Professora Carmem Massarotto. Disponível em: <https://www.ribeiraopreto.sp.gov.br/seducacao/escolas /masaroto/i15masaroto.php>. Acesso em: 20 maio 2015.

RAFFAINI, Patrícia Tavares. Esculpindo a Cultura na Forma Brasil: o Departamento de Cultura de São Paulo (1935-1938). São Paulo: Humanitas/FFLCH, 2001.

REGISTRO, Tânia Cristina. Biografias dos governantes de Ribeirão Preto: poder executivo (presidentes da câmara, intendentes e prefeitos). 2013. No prelo.

RIBEIRÃO PRETO. Almanaque 2000. Arquivo Municipal e Arquivo Revide. Ribeirão Preto: MIC Editorial, 2000. 
Lei $\mathrm{n}^{\circ} 333$, de 11 de novembro de 1953. Cria o Parque Infantil do

Bosque "Fábio Barreto". Disponível em:

$<$ http://www.ribeiraopreto.sp.gov.br/leis/pesquisa/ver.php?id=28744\&chave=parque+infantil >. Acesso em: 10 out. 2013.

Lei $\mathrm{n}^{\circ} 345$, de 10 de março de 1954 . Abre crédito especial para construção de parque infantil em Vila Virginia. Disponível em: <http://www.ribeiraopreto .sp.gov.br/leis/pesquisa/ver.php?id=28804\&chave=parque+infantil $>$. Acesso em: 10 out. 2013.

Lei $\mathrm{n}^{\circ}$ 421, de 20 de junho de 1955a. Declara de utilidade pública, terreno para construção do parque infantil de Vila Tibério. Disponível em: $<$ http://www.ribeiraopreto.sp.gov.br/leis/pesquisa/ver.php?id=29113\&chave=parque+infantil >. Acesso em: 10 out. 2013.

. Lei $\mathrm{n}^{\circ} 443$, de 05 de julho de 1955b. Denomina o Parque Infantil do Barracão de "Peixe Abbade". Disponível em: <http://www.ribeiraopreto.sp.gov.br/leis/ pesquisa/ver.php?id=29161\&chave=parque+infantil>. Acesso em: 10 out. 2013.

Lei $n^{\circ} 425$, de 11 de julho de 1955 c. Cria o Parque Infantil do Distrito de Bonfim Paulista. Disponível em: <http://www.ribeiraopreto.sp.gov.br/leis/pesquisa/ver . php?id=29120\&chave=parque+infantil $>$. Acesso em: 10 out. 2013.

. Lei $\mathrm{n}^{\circ}$ 547, de 26 de fevereiro de 1957a. Cria Parque Infantil no bairro de Vila Tibério. Disponível em: <http://www.ribeiraopreto.sp.gov.br/leis/pesquisa/ver.php ?id=28766\&chave=parque+infantil $>$. Acesso em: 10 out. 2013.

Lei $\mathrm{n}^{\circ}$ 588, de 17 de agosto de 1957b. Denomina o Parque Infantil de Vila Tibério de "Do . Anita Procópio Junqueira". Disponível em: $<$ http://www.ribeiraopreto.sp.gov.br/leis/pesquisa/ver.php?id=28894\&chave=parque+infantil $>$. Acesso em: 18 mar. 2014.

Lei no 820, de 06 de março de 1959a. Denomina Parque Infantil "Santa Maria Goretti". Disponível em: < http://www.ribeiraopreto.sp.gov.br/leis/pesquisa/ver.php?id= 30233\&chave $=$ parque+infantil $>$. Acesso em: 10 abr. 2014.

Lei $\mathrm{n}^{\circ} 857$, de 18 de setembro de 1959 b. Autoriza construção de piscina no parque infantil "Maria Goretti", em Vila Virginia. Disponível em: $<$ http://www.ribeiraopreto.sp.gov.br/leis/pesquisa/ver.php?id=30531\&chave=parque+infantil $>$. Acesso em: 10 out. 2013.

Lei n ${ }^{\circ} 890$, de 03 de dezembro de 1959c. Cria Parque Infantil de Vila Paulista. Disponível em: <http://www.ribeiraopreto.sp.gov.br/leis/pesquisa/ver.php?id=30521 \&chave=parque+infanti $>$. Acesso em: 10 out. 2013.

Lei $\mathrm{n}^{\circ}$ 1274, de 27 de dezembro de 1962a. Cria um Parque Infantil no bairro de Santa Cruz do José Jacques. Disponível em: $<$ http://www.ribeiraopreto.sp.gov.br/leis/pesquisa/ver.php?id=28534\&chave=parque+infantil $>$. Acesso em: 19 ago. 2014. 
Lei $\mathrm{n}^{\circ}$ 1276, de 27 de dezembro de 1962b. Autoriza despender até cr\$ 5.000.000,00, para construção de um Parque Infantil no bairro de Vila Paulista. Disponível em: <http://www.ribeiraopreto.sp.gov.br/leis/pesquisa/ver.php?id=28536\&chave=parque+in fantil>. Acesso em: 19 ago. 2014.

Decreto $\mathrm{n}^{\circ}$ 004, de 05 de fevereiro de 1963a. Denomina de parque infantil dos Bandeirantes o parque construído na Vila Recreio. Disponível em: $<$ http://www.ribeiraopreto.sp.gov.br/leis/pesquisa/ver.php?id=27787\&chave=parque+infantil $>$. Acesso em: 19 ago. 2014.

Decreto ${ }^{\circ}$ 010, de 21 de fevereiro de 1963b. Denomina oficialmente de "Prof. Conceição Monteiro de Barros" uma das escolas municipais. Disponível em: <http://www.ribeiraopreto.sp.gov.br/leis/pesquisa/ver.php?id=27807\&chave=parque+infantil $>$. Acesso em: 19 ago. 2014.

. Lei $\mathrm{n}^{\circ} 1282$, de 21 de fevereiro de 1963c. Autoriza a construção de um parque infantil no bairro da Lapa. Disponível em:

<http://www.ribeiraopreto.sp.gov.br/leis/pesquisa/ver.php?id=28544\&chave=parque+infantil >. Acesso em: 19 ago. 2014.

Lei $\mathrm{n}^{\circ} 1291$, de 08 de abril de 1963d. Cria o Parque Infantil de Vila Recreio. Disponível em: <http://www.ribeiraopreto.sp.gov.br/leis/pesquisa/ver.php?id= 28569\&chave=parque+infantil $>$. Acesso em: 19 ago. 2014.

. Lei $\mathrm{n}^{\circ} 1475$, de 10 de novembro de 1964a. Autoriza construção de um Parque Infantil em Vila Abranches. Disponível em: $<$ http://www.ribeiraopreto.sp.gov.br/leis/pesquisa/ver.php?id=28075\&chave=parque+infantil $>$. Acesso em: 10 out. 2014.

Lei $\mathrm{n}^{\circ} 1507$, de 01 de dezembro de 1964b. Cria um Parque Infantil em Vila Seixas. Disponível em: <http://www.ribeiraopreto.sp.gov.br/leis/pesquisa/ver.php?id= 28188\&chave=parque+infantil $>$. Acesso em: 10 out. 2014.

Decreto $\mathrm{n}^{\circ}$ 067, de 07 de dezembro de 1965. Desapropria área de terra destinada a construção de parque infantil, no bairro da Lapa. Disponível em: $<$ http://www.ribeiraopreto.sp.gov.br/leis/pesquisa/ver.php?id=28353\&chave=parque+infantil >. Acesso em: 19 ago. 2014.

Lei no 2039, de 15 de janeiro de 1968a. Denomina de "Da. Iria Junqueira", o parque infantil de Bonfim Paulista. Disponível em: <http://www.ribeiraopreto.sp.gov.br/leis/pesquisa/ver.php?id=26714\&chave=parque+infantil $>$. Acesso em: 19 ago. 2014.

Decreto $\mathrm{n}^{\circ}$ 147, de 26 de dezembro de 1968b. Denomina de "padre Emílio Jarbinet", o parque infantil no bairro da Lapa. Disponível em: <http://www.ribeiraopreto.sp.gov.br/leis/pesquisa/ver.php?id=27138\&chave=parque+infantil >. Acesso em: 19 ago. 2014.

Decreto $\mathrm{n}^{\circ} 123$, de 29 de agosto de 1969. Abre crédito suplementar de Cr\$ 2.000,00 (dois mil cruzeiros novos) para suplementação da verba 3/3.1.2.0-61 - distrito de 
Bonfim Paulista - escolas e parque infantil - material de consumo. Disponível em: $<$ http://www.ribeiraopreto.sp.gov.br/leis/pesquisa/ver.php?id=27038\&chave=>. Acesso em: 8 out. 2014.

Decreto $\mathrm{n}^{\circ} 168$, de 12 de setembro de 1972. Declara de utilidade pública área de terreno localizada nesta cidade, no bairro de Vila Tibério, destinada à ampliação do parque infantil de Vila Lobato. Disponível em:

<http://www.ribeiraopreto.sp.gov.br/leis/pesquisa/ver.php?id=25261\&chave=parque+infantil $>$. Acesso em: 19 ago. 2014.

Lei $\mathrm{n}^{\circ}$ 2756, de 14 de maio de 1973a. Cria um Parque Infantil no bairro Vila Lobato. Disponível em: <http://www.ribeiraopreto.sp.gov.br/leis/pesquisa/ver.php?id=24 511\&chave=parque+infantil $>$. Acesso em: 10 out. 2013.

Lei $n^{\circ} 2763$, de 05 de Junho de 1973b. Dispõe sobre a organização da administração municipal de ribeirão preto, estabelece diretrizes para a reforma administrativa e dá outras providências, Ribeirão Preto, Diário Oficial, 1973.

Lei $\mathrm{n}^{\circ}$ 2897, de 17 de Junho de 1974a. Cria as Secretarias Municipais de Negócios Jurídicos e Internos da Educação, Saúde e Bem Estar Social e de Planejamento, 1974.

Lei $\mathrm{n}^{\circ}$ 2903, de 25 de junho de 1974b. Abre crédito especial de Cr\$ 200.000,00, para construção de um parque infantil no Distrito de Guatapará. Disponível em: <http://www.ribeiraopreto.sp.gov.br/leis/pesquisa/ver.php?id=23318\&chave=parque+infantil $>$. Acesso em: 10 out. 2013.

Decreto n ${ }^{\circ} 191$, de 07 de setembro de 1975a. Abre crédito suplementar de Cr\$24.550,00, para suplementação da dotação: 4.8/3.1.2.0-08-42-189 - material de consumo - parque infantil - administração regional do Distrito de Bonfim Paulista. Disponível em: <http://www.ribeiraopreto.sp.gov.br/J321/pesquisa.xhtml?lei=23223>. Acesso em: 8 out. 2014.

Decreto $n^{\circ}$ 376, de 01 de dezembro de 1975b. Denomina de "Professora Áurea Aparecida Braghetto Machado", o parque infantil do Bairro de Vila Lobato. Disponível em: <http://www.ribeiraopreto.sp.gov.br/leis/pesquisa/ver.php?id=23466\&chave=parque+ infantil>. Acesso em: 10 out. 2013.

Lei $n^{\circ} 3334$, de 06 de julho de 1977a. Cria um Parque Infantil na Vila da Fraternidade. Disponível em: <http://www.ribeiraopreto.sp.gov.br/leis/pesquisa/ver. php?id=22098\&chave=parque+infantil $>$. Acesso em: 13 nov. 2013.

Ato $\mathrm{n}^{\circ} 132$, de 31 de Julho de 1977b. Dispõe sobre a divisão da Secretaria da Educação, Saúde e Bem Estar Social, 1977.

Lei n$^{\circ} 3618$, de 17 de maio de 1979. Dispõe sobre a criação de parque infantil em Vila Albertina e dá outras providências. Disponível em: $<$ http://www.ribeiraopreto.sp.gov.br/leis/pesquisa/ver.php?id=21233\&chave=parque+infantil $>$. Acesso em: 13 nov. 2013. 
Lei $\mathrm{n}^{\circ} 3839$, de 10 de outubro de 1980a. Altera a denominação dos parques infantis para escolas básicas de $1^{\circ}$ grau. Disponível em: <http://cm.jusbrasil.com.br/legislacao/690912/lei-3839-80>. Acesso em: 10 nov. 2013.

Lei $\mathrm{n}^{\circ} 3889$, de 15 de dezembro de 1980 b. Unifica escolas municipais e transfere da classe de bens de uso comum para a de uso especial à área correspondente à Praça "Antônio Prado". Disponível em: <http://cm.jusbrasil.com.br/legislacao/690862/lei-3889-80>. Acesso em: 8 out. 2014.

Decreto $n^{\circ} 333$, de 26 de dezembro de 1983. Define e delimita setores e subsetores no distrito sede do município de Ribeirão Preto, Ribeirão Preto, Diário Oficial, 1983.

ROLIM, Inácio. Educação Física nas classes trabalhistas: estudos e conferências. Rio de Janeiro: Departamento de Imprensa e Propaganda, 1942.

ROSEMBERG. Fúlvia. A educação pré-escolar brasileira durante os governos militares. Cad. Pesq., São Paulo, n. 82, p. 21-30, ago. 1992.

SANDRONI, Luciana. O Mário que não era de Andrade: o Menino da Cidade Lambida pelo Igarapé Tietê. 1. ed. São Paulo: Companhia das Letrinhas, 1988.

SANTOS, Joel Rufino dos. História Política do Futebol. São Paulo: Braziliense, 1981.

SANTOS, Maria Walburga dos. Educadoras de parques infantis em São Paulo: aspectos de sua formação e prática entre os anos de 1935 e 1955. 2005. 299f. Dissertação (Mestrado em História e Histografia da Educação)-Faculdade de Educação, Universidade de São Paulo, 2005 .

SÃO PAULO (Município). Acto $\mathrm{n}^{\circ} 767$, de 9 de janeiro de 1935. In: Revista do Arquivo Municipal de São Paulo, v. IX, 1935a.

Acto ${ }^{\circ}$ 861, de 30 de maio de 1935. In: Revista do Arquivo Municipal de São Paulo, v. XII, 1935 b.

(Estado). Decreto n ${ }^{\circ} 4855$, de 27 de janeiro de 1931. Cria o

Departamento de Educação Física do Estado de São Paulo, 1931.

Decreto ${ }^{\circ}$ 9605, de 12 de outubro de 1938. Reorganiza o Departamento de Educação Física do Estado de São Paulo. SET: coletânea de leis e decretos: legislação atualizada até dezembro de 1977, São Paulo, p. 120-121, 1978.

Decreto $\mathrm{n}^{\circ} 10243$, de 20 de maio de 1939. Dispõe sobre a educação física no Estado. Revista de Educação. São Paulo, v. 23/26, p. 178-179, set/dez e mar/jun, 1939.

Decreto $n^{\circ} 14334$, de 30 de novembro de 1944. Dispõe sobre a Divisão Administrativa do Município de Ribeirão Preto, São Paulo, Diário Oficial, 1944. 
Lei-estadual $n^{\circ} 2456$, de 30 de dezembro de 1953. Altera a

denominação do Distrito de Gaturamo, Diário Oficial, 1953.

Lei-estadual $n^{\circ}$ 8092, de 28 de fevereiro de 1964. Desmembra os

Municípios de Ribeirão Preto e Dumont, Diário Oficial, 1964.

Lei-estadual $n^{\circ} 6645$, de $1^{\circ}$ de janeiro de 1990. Desmembra os

Municípios de Ribeirão Preto e Guatapará, Diário Oficial, 1990.

SCHWARTZMAN, Simon; BOMENY, Helena Maria Bousquet; COSTA, Vanda Maria Ribeiro. Tempos de Capanema. São Paulo: Paze Terra/FGV, 2000.

SILVA, Carolina da Costa e. O álbum "Parques Infantis" como objeto cultural: (São Paulo, 1937). 2008. 202 f. Dissertação (Mestrado em Educação)-Faculdade de Educação, Universidade de São Paulo, São Paulo, 2008.

SILVEIRA, Sirlei A. Nas trilhas da brasilidade (Mário de Andrade e o projeto de construção da nação brasileira). 1993.Dissertação (Mestrado)-PUC, São Paulo, 1993.

SOUZA, Maria José Sampaio. Os parques infantis. In: COSTA, João Emboaba da (Org.). Álbum comemorativo do $1^{\mathbf{0}}$ centenário da fundação da cidade do Ribeirão Preto. Ribeirão Preto, 1956.

TEODORO, Michelle Moraes. Reconstrução histórica da educação pública infantil em Campinas (1940- 1996). Monografia (Trabalho de conclusão de curso)-Faculdade de Educação, Universidade Estadual de Campinas, Campinas, 2005.

VIDAL, Diana G.; PAULILO, André Luiz. Projetos e Estratégias de Implementação da Escola Nova na capital do Brasil (1922-1935). In: MAGALDI, Ana; ALVES, Claudia; GONDRA, José G. (Orgs.). Educação no Brasil: história, cultura e política. Bragança Paulista: EDUSF, 2003.

VIEIRA, Sandra Aparecida Bassetto. Os parques infantis da cidade de São Paulo (19351938): análise do modelo didático-pedagógico. Revista de Iniciação Científica da FFC, Marília, v. 4, n. 1, 2004.

WALKER, Thomas W.; BARBOSA, Agnaldo de Souza. Dos coronéis à metrópole: fios e tramas da sociedade e da política em Ribeirão Preto no século XX. Ribeirão Preto: Palavra Mágica, 2000. 